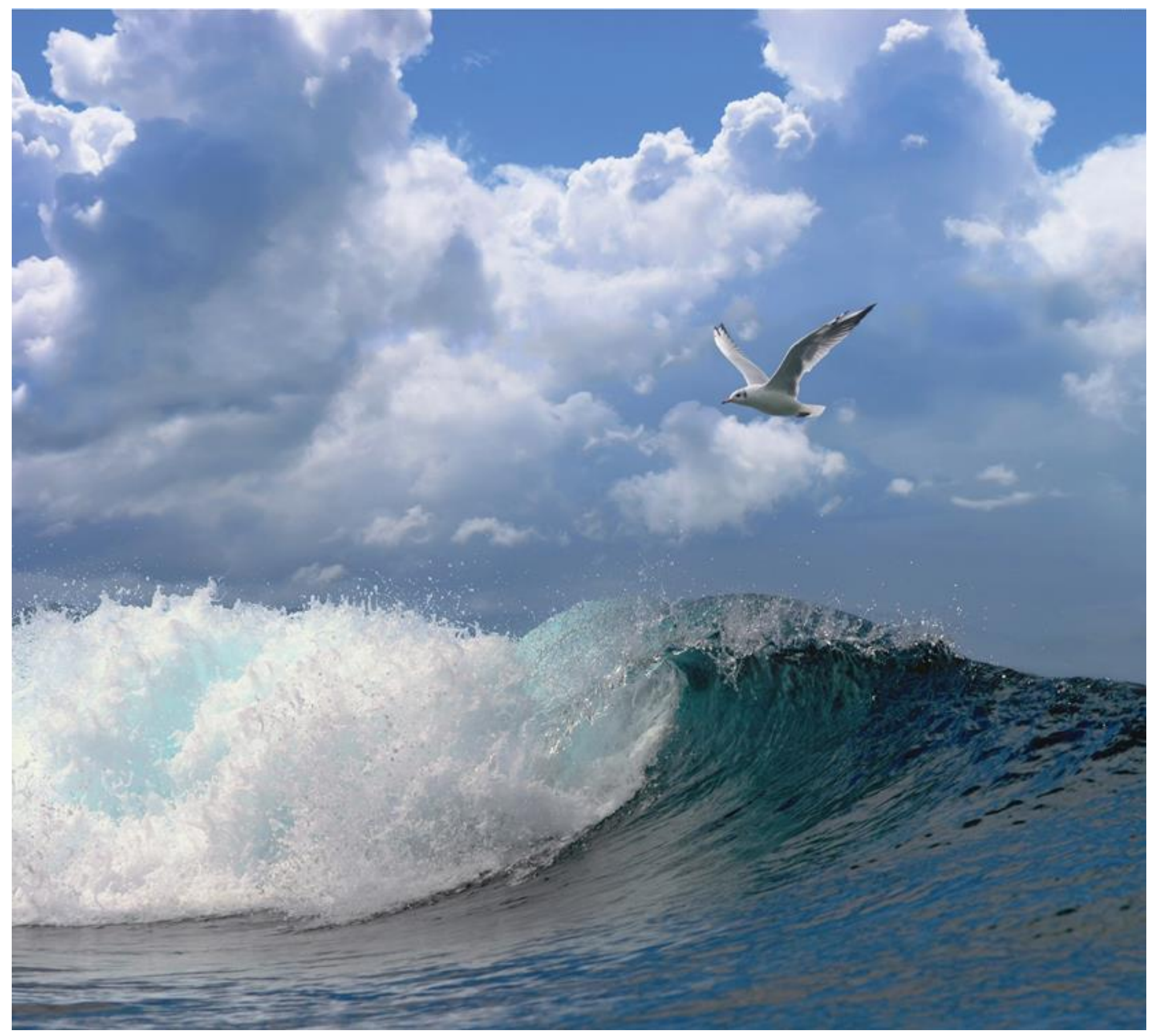

\title{
Prognose visstand in en rond het Haringvliet na invoering van het Kierbesluit in 2018
}

Auteurs: A.B. Griffioen, H.V. Winter, R. van Hal.

Mogelijk gemaakt door

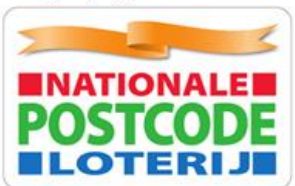

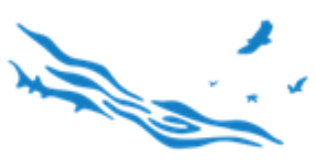

Haringuliet
Wageningen University \&

Research Rapport C081/17 


\section{Prognose visstand in en rond het Haringvliet na invoering van het Kierbesluit in 2018.}

Auteurs: $\quad$ A.B. Griffioen, H.V. Winter, R. van Hal

\section{Publicatiedatum: oktober 2017}

Dit onderzoek is uitgevoerd door Wageningen Marine Research in opdracht van Sportvisserij Nederland in het kader van het deelproject Monitoring als onderdeel van het project Haringvliet, gefinancierd door het Droomfonds van de Nationale Postcode Loterij.

Projectnummer 4316100058

Wageningen Marine Research IJ muiden, oktober 2017

Mogelijk gemaakt door
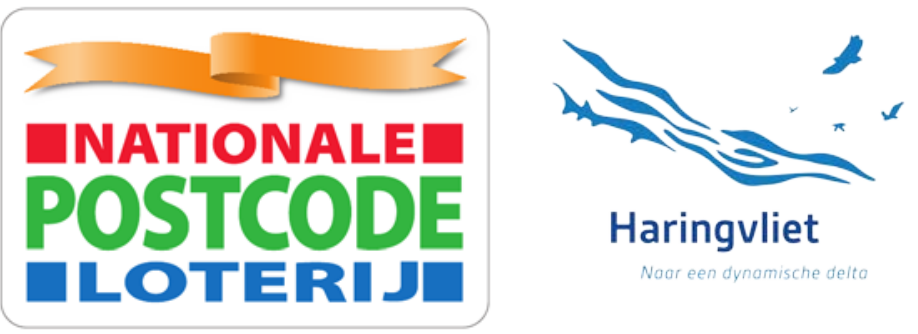

\section{Haringuliet}

Noor een dynomische delta 
A.B. Griffioen, H.V. Winter, R. van Hal. Wageningen Marine Research Wageningen UR (University \& Research centre), Wageningen Marine Research rapport C081/17. 53 blz

Trefwoorden: vismigratie, Haringvliet, Kierbesluit, barrières, herstel trekvispopulaties

\author{
Opdrachtgever: Sportvisserij Nederland \\ Niels Breve \\ Leijenseweg 115, 3721 BC Bilthoven \\ breve@sportvisserijnederland.nl \\ 030-6058437
}

Dit rapport is gratis te downloaden van: https://doi.org/10.18174/425507

Wageningen Marine Research verstrekt geen gedrukte exemplaren van rapporten

Wageningen Marine Research Wageningen UR is ISO 9001: 2008 gecertificeerd.

\title{
(C) 2017 Wageningen Marine Research Wageningen UR
}

Wageningen Marine Research, onderdeel van Stichting Wageningen Research KvK nr. 09098104,

WMR BTW nr. NL 8113.83.696.B16. Code BIC/SWIFT address: RABONL2U IBAN code: NL 73 RABO 0373599285
De Directie van Wageningen Marine Research is niet aansprakelijk voor gevolgschade, noch voor schade welke voortvloeit uit toepassingen van de resultaten van werkzaamheden of andere gegevens verkregen van Wageningen Marine Research opdrachtgever vrijwaart Wageningen Marine Research van aanspraken van derden in verband met deze toepassing.

Dit rapport is vervaardigd op verzoek van de opdrachtgever hierboven aangegeven en is zijn eigendom. Niets uit dit rapport mag weergegeven en/of gepubliceerd worden, gefotokopieerd of op enige andere manier gebruikt worden zonder schriftelijke toestemming van de opdrachtgever. 


\section{Inhoud}

$\begin{array}{lr}\text { Samenvatting } & \mathbf{5}\end{array}$

$\begin{array}{lll}1 & \text { Inleiding } & 7\end{array}$

2 Visstand Haringvliet van verleden naar heden $\quad 9$

2.1 Het Haringvliet $\quad 9$

2.1.1 Locatiebeschrijving $\quad 9$

2.1.2 Vigerend beleid en aangewezen doelsoorten vis $\quad 10$

$\begin{array}{lll}2.2 & \text { Het belang van het herstel van migratieroutes } & 10\end{array}$

2.3 Historische situatie visstand in het Haringvliet $\quad 11$

$\begin{array}{lll}2.4 & \text { Huidige situatie visstand in het Haringvliet } & 13\end{array}$

3 Spuisluizen Haringvlietdam op een 'Kier' als herstelmaatregel 14

3.1 Lozingsprogramma Haringvlietsluizen (LPH 84) 14

3.2 Haringvlietsluizen Operationeel Programma (HOP) 15

$\begin{array}{lll}3.3 & \text { Kierbesluit: lerend implementeren } & 15\end{array}$

3.3.1 Migratievensters Kier: dynamiek in tijd en ruimte $\quad 18$

3.3.2 Dynamiek in habitats rondom de Haringvlietdam 20

$\begin{array}{lll}3.4 & \text { Zoetspoelen } & 22\end{array}$

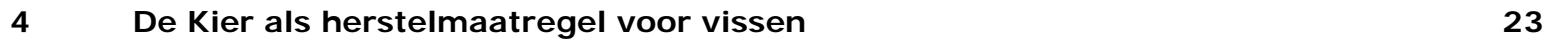

4.1 Nederland als delta van grote rivieren 23

4.2 Haringvlietdam als corridor: potentiële migratieroutes langs het sluizencomplex in de $\begin{array}{ll}\text { Haringvlietdam } & 24\end{array}$

4.3 Passagemogelijkheden van de spuisluizen met De Kier 26

$\begin{array}{lll}4.4 & \text { Effect van de Kier op (1) diadrome soorten } & 28\end{array}$

$\begin{array}{lll}4.5 & \text { Effect van de Kier op (2) estuariene residente soorten } & 28\end{array}$

$\begin{array}{lll}4.6 & \text { Effect van de Kier op (3) mariene juveniele soorten } & 28\end{array}$

$\begin{array}{lll}4.7 & \text { Effect van de Kier op (4) seizoensgasten } & 29\end{array}$

$\begin{array}{lll}4.8 & \text { Effect van de Kier op (5) zoetwatersoorten } & 29\end{array}$

$5 \quad$ Prognose herstel trekvis populaties $\quad 31$

$\begin{array}{lll}5.1 & \text { Vismigratie kalender Droomfonds } & 31\end{array}$

5.2 Soortspecifieke kenschets en prognose van de effecten van de Kier 33

5.2.1 Europese Aal/Paling (Anguilla anguilla) 33

$\begin{array}{lll}\text { 5.2.2 Bot (Platichthys flesus) } & 35\end{array}$

5.2.3 Driedoornige stekelbaars (Gasterosteus aculeatus) $\quad 35$

5.2.4 Dunlipharder (Liza ramada) 36

5.2.5 Elft (Alosa alosa) 36

$\begin{array}{lll}\text { 5.2.6 Fint (Alosa fallax) } & 37\end{array}$

5.2.7 Atlantische haring (Clupea harengus) 38

5.2.8 Houting (Coregonus oxyrinchus) 38

$\begin{array}{lll}5.2 .9 & \text { Rivierprik (Lampetra fluviatlis) } & 39\end{array}$

5.2.10 Spiering (Osmerus eperlanus) $\quad 40$

$\begin{array}{ll}5.2 .11 & \text { Sprot (Sprattus sprattus) }\end{array}$

5.2.12 Europese steur (Acipenser sturio) $\quad 41$

5.2.13 Atlantische zalm (Salmo salar) $\quad 42$

5.2.14 Zeebaars (Dicentrarchus labrax) 42

5.2.15 Zeeforel (Salmo trutta) 43

5.2.16 Zeeprik (Petromyzon marinus)

5.2.17 Overzicht, prognose effect van de Kier op de 16 soorten van de vismigratiekalender $\quad 45$

5.3 Consequenties van De Kier voor trekvis: Q\&A's 46 
$7 \quad$ Kwaliteitsborging

51

Verantwoording

52 


\section{Samenvatting}

Op 20 mei 2015 zetten de directeuren van Wereld Natuur Fonds, Natuurmonumenten, Sportvisserij Nederland, Staatsbosbeheer, Vogelbescherming Nederland en ARK, hun handtekening onder de samenwerkingsovereenkomst voor het project 'Natuurherstel Haringvliet'. Het Haringvliet vormt het oorspronkelijke estuarium van de rivieren Rijn en Maas. Het project "Natuurherstel Haringvliet" heeft tot doel de unieke deltanatuur in het Haringvliet weer tot leven te wekken o.a. door herstel van de oorspronkelijke vismigratieroutes. Sinds 1970 is het Haringvliet van de zee afgesloten en het unieke deltaleven tot stilstand is gekomen.

Volgens het Kierbesluit, in de volksmond 'de Kier', zal vanaf 2018 met opkomend tij zout water via de spuisluizen van de Haringvlietdam het Haringvliet worden ingelaten. Dit heeft tot doel vissen weer beter de kans te geven het Haringvliet op te zwemmen. Vissoorten die om hun levenscyclus te voltooien vanuit zee rivieren op trekken kunnen hiervan profiteren door met de gecreëerde waterstroom het Haringvliet en vervolgens de Rijn of Maas op te zwemmen. De voorliggende rapportage geeft inzicht in de technische maatregelen van het geplande beheer van de spuisluizen (de Kier) en een prognose van de gevolgen voor de vissoorten die het Haringvliet benutten.

De centrale vraag in deze rapportage is: 'Hoe ontwikkelt de visstand zich in het Haringvliet na instelling van de 'Kier' en welke factoren zijn hierbij van belang?' Het is onmogelijk om de gevolgen van de Kier voor de visstand met grote nauwkeurigheid vooraf te bepalen. Om deze reden is de prognose grotendeels bepaald op basis van de beschikbare beheerprotocollen, een systeemprognose van Deltares, literatuur en expert judgement.

Het openen van de Kier beoogt het herstel van de vismigratieroute. Het openen van de Kier leidt echter niet tot een natuurlijke estuariene situatie in het Haringvliet. In een natuurlijk estuarium is de zoutindringing sterk afhankelijk van de afvoer van de rivier en de getijdeslag in het systeem. Juist in de periode dat in de natuurlijke situatie het zoute water het verste landinwaarts trekt, als de rivierafvoer laag is dus met name in de periode september-oktober, wordt de Kier gesloten en daardoor de migratieroute voor langere periode geblokkeerd. Naast de directe gevolgen van de blokkade van de migratieroute heeft dit ook effect op de waterkwaliteit in het Haringvliet en op de aanwezige (macro) flora en fauna. Ook de getijdeslag in het Haringvliet wijzigt nauwelijks ten opzichte van de huidige situatie en blijft dus zeer beperkt. Dit gaat een herstel van een zoetwatergetijde gebied tegen waar een soort als de fint afhankelijk van is.

In deze prognose wordt vooral ingegaan - op hoofdlijnen - op de visgilden zoals deze zijn beschreven voor de Kaderrichtlijn Water. Het betreft hier zoetwatervissen, estuariene residenten, marien juveniele, mariene seizoensgasten en diadrome vissen. Deze laatste groep is het meest afhankelijk van een hersteld estuarium met vrije migratie tussen zoet en zout. Om deze reden wordt deze groep meer in detail besproken samen met enkele zoutwatersoorten welke zijn uitgekozen door de partners van het Droomfonds als relevante soorten voor het Haringvliet en de Voordelta op basis van historische en actuele visstand informatie. De diadrome vissen zullen profiteren van de verbeterde intrekmogelijkheden richting het Haringvliet. Echter, populatieherstel is afhankelijk van meerdere factoren dan alleen een verbeterde verbinding tussen zoet en zout water, zoals de kwaliteit van paai en opgroeigebieden elders in het riviersysteem.

Estuarien residenten (o.a. bot, brakwatergrondel en botervis) hebben in principe baat bij een herstel van een natuurlijke zoet-zout gradiënt. Echter, door het sluiten van de Kier bij een lage rivierafvoer zullen er in die perioden geen of nauwelijks brakwater gebieden zijn. Brakwater putten zouden als zogenoemde refugia kunnen dienen. Het is onbekend of deze vissoorten deze refugia kunnen vinden en zullen benutten. Voor estuarien residenten is een verdergaand herstel van het continue karakter van een functioneel estuarium nodig. 
Voor marien juveniele (o.a. haring, zeebaars, schar, schol en steenbolk) en seizoensmigranten (sprot) vormt de Kier een betere intrek mogelijkheid maar zal het zoutgehalte aan de binnenzijde van het Haringvliet voor veel soorten te laag zijn en teveel fluctueren om veel extra opgroeihabitat te creëren. Soorten als haring en sprot met een wat grotere tolerantie voor een fluctuerende saliniteit kunnen mogelijk wel profiteren van extra opgroeigebied, mits dit zoute/brakke water aanwezig is voor langere perioden.

Voor diadrome soorten (trekvissen) zoals driedoornige stekelbaars, paling en bot heeft de Kier als gevolg dat ze zullen profiteren van de verbeterde intrekmogelijkheden. Diadrome soorten die meer lokaal kunnen opgroeien zoals (de diadrome variant van) de driedoornige stekelbaars, aal en bot zullen waarschijnlijk in aantal toenemen. Het Haringvliet is slechts één van de opgroeigebieden voor deze soorten en daarom zal dit gebied zeker niet bepalend zijn voor een populatieherstel in zijn geheel. Daarnaast spelen voor veel soorten zoals de aal meer factoren mee voor een populatie herstel. Ook zal de Kier kunnen bijdragen aan de draagkracht van zeeforel. De Kier bijdragen aan de populatie zeeprik en rivierprik waarvan wordt aangenomen dat er stroomopwaarts voldoende paai en opgroeigebied is en voornamelijk de intrek een knelpunt vormt. Voor zalm zal de Kier bijdragen aan een verbeterde intrek, maar net als voor de terugkeer van de steur en fint zal er meer nodig zijn dan de Kier om het herstel van de populaties te verbeteren. Voor alle (trek)vissen geldt: het herstel van vispopulaties is zo sterk als de zwakste schakel in het gehele systeem in de gehele levenscyclus.

De zoetwatervis (o.a. snoekbaars, baars en blankvoorn) zal mogelijk profiteren van de Kier doordat er minder vissen worden uitgespoeld. De verspreiding van zoetwatervis in het Haringvliet wordt 'begrensd' door de zoet-zout gradiënt, welke in de huidige situatie om en nabij de Haringvlietdam ligt. Hierdoor houden zoetwatervissen zich op tot aan de Haringvlietdam waar ze het risico lopen uitgespoeld te worden naar zee met het spuien. Als door openstelling van de Kier de zoet-zout gradiënt landinwaarts bij de dam vandaan verschuift, komen zoetwatervissen mogelijk minder snel in de buurt van de Haringvlietdam en neemt het risico op uitspoelen af. Bovendien vergroot de Kier de terugkeerkansen voor toch uitgespoelde zoetwatervissen. Of het uitspoelen van zoetwatervis werkelijk afneemt door de Kier is onbekend. Echter, bij gemiddelde afvoeren $\left(2200 \mathrm{~m}^{3} / \mathrm{s}\right)$ zal de zoet-zout gradiënt alsnog bij de dam liggen en is het uitspoelrisico waarschijnlijk nauwelijks kleiner zijn dan in de huidige situatie. De verspreiding van zoetwatervis zal zich mogelijk aanpassen door een dynamische verplaatsing ten opzichte van de zoet zout gradiënt. 


\section{I nleiding}

Op 20 mei 2015 zetten de directeuren van Wereld Natuur Fonds, Natuurmonumenten, Sportvisserij Nederland, Staatsbosbeheer, Vogelbescherming Nederland en ARK, hun handtekening onder de samenwerkingsovereenkomst voor het project 'Natuurherstel Haringvliet'. Het Haringvliet vormt het oorspronkelijke estuarium van de rivieren Rijn en Maas. Het project "Natuurherstel Haringvliet" heeft tot doel de unieke deltanatuur in het Haringvliet weer tot leven te wekken o.a. door herstel van de oorspronkelijke vismigratieroutes. Sinds 1970 is het Haringvliet van de zee afgesloten en het unieke deltaleven tot stilstand is gekomen.

De Nederlandse rivieren en de estuaria (waaronder het Haringvliet) zijn sinds 1820 onderwerp van grootschalige, door de mens aangebrachte, veranderingen (Quak 2016). In de periode vanaf de zogenoemde 'Tulla-correctie' in de Hochrein rond 1820 tot aan het afsluiten van de Brielse Maas en het Haringvliet (1970) hebben diverse maatregelen ertoe geleid dat de ecologie en de dynamiek van het gebied drastisch is veranderd met alle gevolgen van dien voor diverse vissoorten en hun opgroei, paai en foerageer gebieden. Hoewel het Haringvliet in de Kaderrichtlijn Water wordt getypeerd als een overgangswater (type $\mathrm{O} 2$ ), is het Haringvliet in de huidige situatie een volledig zoetwatersysteem. In 1970 werd de Haringvlietdam opgericht als onderdeel van grootschalige deltawerken, en sindsdien bestaat bij de dam een harde gradiënt tussen zoet rivierwater en het zoute water van de Noordzee. Vanaf 2018 zullen de spuisluizen van de Haringvlietdam anders beheerd worden, zodanig dat hierdoor met vloed ook zeewater het Haringvliet kan binnenkomen (de Kier). De Kier heeft als doel herstel van internationale vismigratie tussen de Noordzee en de rivieren Rijn en Maas. Dit onder de randvoorwaarden van behoud zoet water in het Haringvliet, scheepvaart en hoogwaterveiligheid. Daarbij zal zout water beperkt in het Haringvliet worden toegelaten om op die manier een zoet-zout gradiënt te creëren en een stuk herstel te bieden aan het estuarium.

Ondanks het herstel van vismigratiemogelijkheden middels de Kier, is het op moment van schrijven nog onbekend wat de effecten van de Kier precies zullen zijn op de visstand in het Haringvliet en in de nabije omgeving. Het implementeren van de Kier zal geleidelijk worden ingevoerd. Dit wordt het 'lerend implementeren' genoemd. In dit traject zullen eerst diverse vragen met name omtrent zoet-zout gradiënt beantwoord moeten worden. Op basis van dit 'lerend implementeren' zal in het beheer van de spuisluizen vanaf 2018 een verdere optimalisatie van de Kier worden doorgevoerd. Daarom kan in voorliggend rapport slechts een prognose worden gegeven over de verwachte ontwikkelingen van de visstand. Hetzelfde geldt voor de benthos, de flora en de andere fauna zoals bijvoorbeeld kustbroedvogels. Wel is het mogelijk om een prognose te geven van de Kier op de diadrome vissoorten, er vanuit gaande dat de passeerbaarheid van de Haringvlietdam voor diadrome vissoorten in elk geval gaat verbeteren.

Voorliggend rapport geeft een prognose over de visbestanden in en rond het Haringvliet en is deels gebaseerd op een beschrijving van zowel de historische als de huidige situatie van de visstand en de visserij, respectievelijk Quak (2016) en Hop (2011, 2016). De kennisvraag die in deze rapportage centraal staat is als volgt gedefinieerd: Hoe ontwikkelt de visstand zich in het Haringvliet na instelling van de 'Kier' en welke factoren zijn hierbij van belang? Om deze kennis vraag te beantwoorden is, naast de rapportages van Quak (2016) en Hop (2011, 2016), ook gebruik gemaakt van een rapportage van Deltares (Noordhuis, 2017) die verder ingaat op het lerend implementeren en de systeemverandering in het Haringvliet. Naast voorliggende prognose over de visbestanden heeft het SOVON in opdracht van de Vogelbescherming Nederland een rapportage opgesteld over de prognose vogelbestanden Haringvliet en omgeving. De rapportages van Deltares, SOVON en Wageningen Marine Research (WMR) vormen een drieluik.

Leeswijzer

Voorliggende rapportage start met korte samenvattingen van de historische en de huidige visbestanden. Deze vormen het startpunt van deze rapportage $(\mathrm{H} 2)$. Vervolgens wordt er in $\mathrm{H} 3$ een technisch overzicht 
gegeven van het implementeren van de Kier, voornamelijk gebaseerd op een rapportage van Deltares (Noordhuis 2017). In H4 wordt op hoofdlijnen een prognose gegeven voor de ontwikkeling van de visstand voor diverse visgilden als gevolg van het implementeren van de Kier. H5 gaat vervolgens uitgebreider in op 16 doelsoorten (voornamelijk diadrome soorten) kenmerkend voor het estuarium van Rijn en Maas. De rapportage sluit af (H5) met enkele Q\&A's (vraag en antwoord) over de consequenties van de Kier voor (trek) vissen. 


\section{Visstand Haringvliet van verleden naar heden}

\subsection{Het Haringvliet}

\subsubsection{Locatiebeschrijving}

Het Haringvliet is een afgesloten zeearm die via een open verbinding tussen de Noordzee (de Voordelta) en het Hollands Diep deel uitmaakt van een deel van de oorspronkelijke delta van de rivieren Rijn en Maas. Het getij in het voormalige brakke getijdengebied is sinds de oprichting van de Deltawerken in 1970 grotendeels weggevallen. Het water werd zoet tot aan de sluizen van de Haringvlietdam en het getij werd sterk beperkt. Het Haringvliet vormt tegenwoordig een groot zoetwaterbekken, dat alleen via de wateren van het Spui, Oude Maas en Nieuwe Waterweg nog in verbinding staat met de Noordzee (Figuur 1). Het waterpeil wordt beïnvloed door de Haringvlietsluizen en de bovenstroomse stuwen. Aan de oevers van Voorne-Putten, de Hoeksche Waard en Goeree-Overflakkee bestaat het landschap uit grasgorzen, riet- en biezenvelden, begroeide en onbegroeide zand- en slikplaten grenzend aan het open water. Een aantal voormalige platen zijn door vooroeververdediging en aanvullingen met grond vermaakt tot redelijk uitgestrekte gebieden (met name de Ventjagersplaten en de Slijkplaat). In het Haringvliet ligt het eiland Tiengemeten. Een deel van de rietlanden en zilte gorzen op dit eiland is door begrazing omgevormd in grasland van brakke bodem (zilverschoonverbond), terwijl onbegraasde delen zich ontwikkeld hebben tot riet, brakke ruigte en struweel.

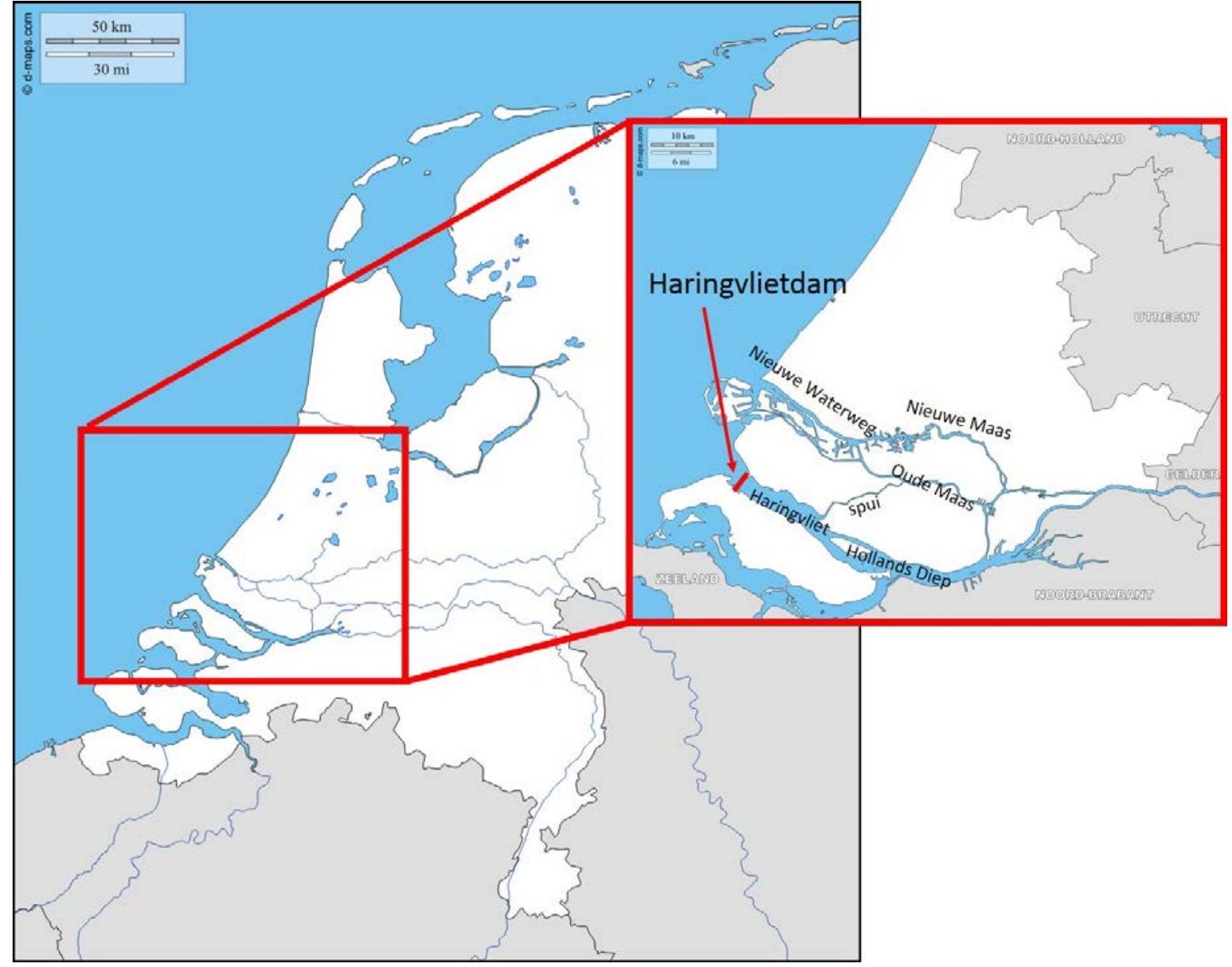

Figuur 2.1: Het Haringvliet en de Haringvliet dam in de huidige situatie (d-maps.com, 2017). 


\subsubsection{Vigerend beleid en aangewezen doelsoorten vis}

Het Haringvliet-West (dat, grofweg, loopt van de Haringvlietdam tot aan de monding van het Spui) is aangewezen als een Natura2000 gebied (evenals de Voordelta) en herbergt de volgende aangewezen habitat-richtlijn soorten: zeeprik, rivierprik, elft, fint, zalm, bittervoorn en de rivierdonderpad. Daarnaast is het Haringvliet binnen de Kader Richtlijn Water (KRW) getypeerd als een overgangswater $\left(\mathrm{O} 2^{1}\right)$. Echter, in de huidige situatie vanaf 1970 tot heden (2017) is het Haringvliet nog een volledig zoetwater systeem. Met de komst van de Kier zal het Haringvliet (mogelijk) meer het karakter krijgen van een overgangswater. In de overgangswateren wordt getoetst op de aanwezigheid (deelmaatlat soortsamenstelling) van bepaalde indicatorsoorten die zijn ingedeeld in de volgende klassen: diadrome soorten, estuariën residenten soorten, marien juveniele soorten, seizoensgasten en zoetwatersoorten. Daarnaast wordt binnen de KRW ook getoetst op het voorkomen (deelmaatlat abundantie) van fint $(0+$, subadult en adult), spiering $(0+$, subadult en adult), haring, bot, slakdolf en pos.

\subsection{Het belang van het herstel van migratieroutes}

Er bestaat veel verschil in de afmetingen van de ruimtelijke schaal die migrerende vissen benutten, zowel in het zoete water als tijdens de zeefase (Figuur 2.2). Een voorbeeld van een vissoort die op grote ruimtelijke schaal migreert is de Atlantische Zalm (Salmo salar). Deze soort zwemt tot ver het stroomgebied van rivieren in (zoals de Rijn en Maas) om te paaien in de snelstromende bovenlopen met grindbanken. Tijdens de zeefase trekt de zalm tot in de Noordelijke Atlantische Oceaan naar de Faeröereilanden en Groenland om daar op te groeien van smolt naar volwassen zalm; een ruimtelijke schaal die vele 1000-en $\mathrm{km}$ beslaat. Een ander voorbeeld van een lange afstand migreerder is de Europese paling (Anguilla anguilla), deze trekt van de benedenstroomse rivieren van het Europese continent ongeveer $6000 \mathrm{~km}$ naar de Sargasso Zee om daar te paaien. Aan het andere kant van het spectrum zitten vissoorten die over duidelijk veel kortere afstanden migreren, zelfs in en rond een estuarium zoals spiering en driedoornige stekelbaars.

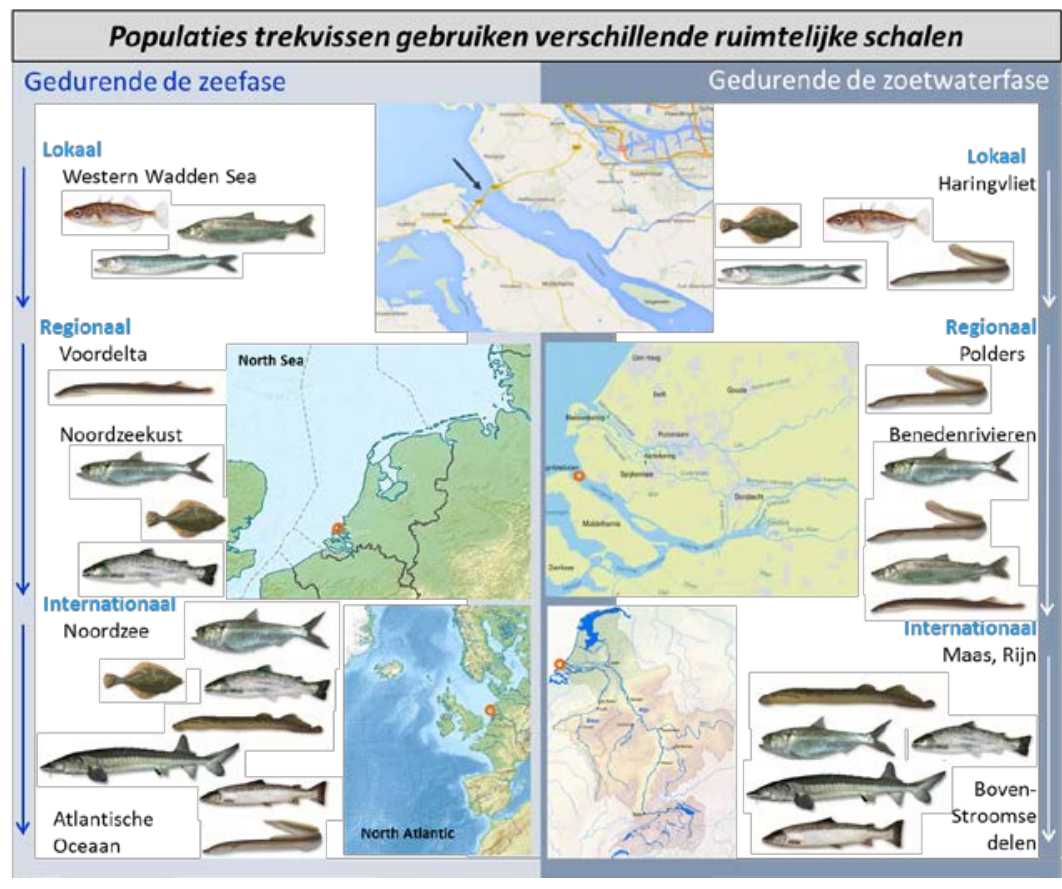

Figuur 2.2. Schematisch overzicht van de variatie aan ruimtelijke schalen die de verschillende soorten riviertrekvissen benutten tijdens zowel de zeefase (links) als de zoetwaterfase (rechts). De ruimtelijke schalen lopen van kleinschalig (lokaal, boven) tot grootschalig (internationaal, beneden).

\footnotetext{
${ }^{1}$ De bemonstering voor de toetsing van de KRW status van een O2 type water vindt normaal gesproken plaats met een ankerkuil (Handboek Hydrobiologie). Deze vismethodiek is echter alleen toepasbaar met stroming (getijde of rivier). In de huidige situatie kan het Haringvliet daarom niet als een $\mathrm{O} 2$ water getoetst worden door het ontbreken van een passende bemonstering zoals wordt gesteld voor de KRW (Graaf et al. 2016). Echter er zijn ontwikkelingen om ook de O2 gebieden welke niet met een ankerkuil zijn te bevissing te toetsen via aangepaste maatlatten (Jager et al. 2015). Overigens is het Haringvliet (evenals grote delen van de beneden rivieren) bestempeld als 'dioxine gebied' wat onder meer betekent dat door te hoge, kritische vervuilingsgraad van de waterbodem en de daarin levende organismen er geen aal voor consumptie meer gevangen mag worden.
} 
Het belang van het oplossen van de vismigratiebarriere Haringvlietdam op de migratieroutes (corridor) verschilt tussen de diverse soorten trekvissen. Echter, migratiebelemmering bij het Haringvliet is niet de enige beperkende factor in de levenscyclus van vissen. Des te groter de ruimtelijke schaal is waarop een populatie acteert, des te meer andere factoren mede bepalen hoe groot een populatie kan zijn. Tenminste de volgende vijf factoren zijn relevant: (1) migratiebarrières (en dus bereikbaarheid) elders in het systeem. Hoe verder een vis moet zwemmen om zijn levenscyclus te voltooien hoe groter het risico dat er op andere locaties ook barrières zijn opgeworpen die net als de Haringvlietdam van invloed zijn op een succesvolle migratie tussen paai- en opgroeigebieden. (2) Visserij speelt een rol met name tijdens de migratie periode als vissen actief heen en weer zwemmen. Het vangsucces van passieve vangtuigen (bijv. fuiken) is sterk afhankelijk van de activiteit van de vis die zelf in het vistuig moet zwemmen. Maar de impact van visserij is ook gebleken uit de pilot van de uitzet van een beperkt aantal steuren waarbij de jonge steuren al vrij snel langs de kust werden teruggevangen (Brevé et al. 2013). De impact van de visserij is ook gebleken uit een onderzoek naar uitgespoelde snoekbaars die na een succesvolle terugkeer in het Haringvliet alsnog weer in de Voordelta zijn teruggevangen (Vis 2017). De derde factor is (3) de habitat kwaliteit van paai- en (op) groeigebieden. Indien vissen (hoge) eisen stellen aan habitat voor bijvoorbeeld de paai, dan is een succesvolle passage langs de Haringvlietdam slechts één van de barrières die overwonnen moeten worden. Als er vervolgens geen geschikt habitat is voor opgroei of paai, is dat de beperkende factor. Als voorbeeld geldt hier de fint die voor een succesvolle paai afhankelijk is van een zoet watergetijden gebied. Dit wordt met de komst van de Kier niet verbeterd (Noordhuis 2017), terwijl de intrekmogelijkheden wel verbeterd. Een vierde factor is de (4) waterkwaliteit. De waterkwaliteit van zowel de zoute als de zoete zijde van de Haringvlietdam kan van invloed zijn op de fysieke gesteldheid van de vis, op zowel de korte als de lange termijn. Hetzelfde geldt voor (5) (exotische) pathogenen. Bijvoorbeeld de parasieten die invasieve vissen met zich mee kunnen dragen zoals de blauwband die drager is van meerdere parasieten, waaronder het zogenaamde Rosette Like Agent (RLA), een besmettelijke eencellige parasiet die sterk negatieve effecten (dodelijk) heeft op het vetje (Spikmans et al. 2010).

Kortom, bij een inschatting van de effecten van de Kier op het herstel van trekvispopulaties moeten ook deze andere potentieel beperkende factoren in ogenschouw worden genomen. De verschillen per soort(groep) zijn op voorhand niet altijd goed in te schatten. Regionale en internationale trekvissen zijn gevoeliger voor een keten aan migratiebarrières dan de lokale soorten. Het herstel van vispopulaties is zo sterk als de zwakste schakel in het gehele systeem in de gehele levenscyclus.

Voordat er een prognose gegeven kan worden over de visbestanden in het Haringvliet en de nabije omgeving, is het van belang om te kijken naar waar we vandaan komen en waar we nu staan t.a.v. visbestanden. In het kader van deelproject Monitoring van het project Haringvliet zijn twee rapporten opgesteld over de historische en de tegenwoordige (2017) visbestanden in en rondom het Haringvliet welke in de volgende paragrafen worden beschreven.

\subsection{Historische situatie visstand in het Haringvliet}

Het bronnenonderzoek van Quak (2016) levert concrete informatie op over de historische situatie van de visstand in het Haringvliet (Tabel 1). Hieronder worden enkele relevante uitkomsten uit de rapportage van Quak (2016) aangehaald.

- Het zuidwestelijke rivieren- en estuariene systeem van Rijn en Maas fungeerde voor alle anadrome trekvissen als 'poort' voor zowel (paai) migratie stroomopwaarts als (juveniele) migratie stroomafwaarts.

- De rivier normalisatie van de Waal en de aanleg van de Merwede vergrootte het debiet richting het Haringvliet en werd daarmee een belangrijke trekroute voor zalmsmolts en als gevolg van homing gedrag ook voor adulte zalmen.

- Zalm trok jaarrond op met een piek in de zomerperiode.

- Voor elft was het Haringvliet al voor de normalisaties een belangrijke route.

- De Rijn anno 2016 is nog slechts een zeer beperkte en kunstmatige afspiegeling van de vroegere Rijn als zalmrivier.

- De historische data leverden informatie over de paaimigratieperioden van steur (vooral juni), elft (vooral april) en fint (april/mei).

- De data indiceren voor zalm, elft en steur visserijdrukken als een belangrijke factor voor de trendmatige afname tussen 1885 en 1900. Riviernormalisaties, waterkrachtcentrales en het 
grootschalig verdwijnen van paai- en opgroeihabitats in Duitsland, Frankrijk, Zwitserland en Luxemburg zijn de factoren die vooral vanaf 1900 hebben geleid tot het verdwijnen van deze trekvissen, mogelijk werd dit proces versneld door de verslechtering van de waterkwaliteit.

- Het in het studiegebied cumulatief aantal waargenomen soorten ( $N=53)$ stemt in hoge mate overeen met het aantal soorten in de Zuiderzee voor de afsluiting in 1932 ( $N=55)$, respectievelijk met het gemiddeld aantal soorten in verschillende estuaria in Noordwest-Europa $(\mathrm{N}=57)$.

- Naast de 'poort' functie, was het systeem vooral functioneel als opgroeigebied voor een groot aantal soorten, zowel voor estuariene soorten (spiering, bot, aal, haring) als juveniele trekvis (zalm, elft, fint, rivierprik). Jaargetijde/seizoen, rivierafvoer, temperatuur en zoutgradiënt geven een dynamisch geheel van factoren en processen met een hoge mate van soortspecifieke betekenis.

- $\quad$ Spiering en jonge haring waren waarschijnlijk in abundantie en productie de 'sleutelsoorten' voor het functioneren van het voedselweb, het ecosysteem en de visserij, met daarnaast een hoge productie van macrofauna zoals garnalen, vlokreeften, aasgarnalen en zoöplankton.

- $\quad$ 'Echte' zoetwatervissen (Quak 2016 geeft geen soorten) waren vooral bij hogere rivierafvoeren in het Hollands Diep en incidenteel in het Haringvliet aanwezig.

Tabel 1 Historische inschatting van abundantie in het Haringvliet voor de afsluiting door de Haringvlietdam in 1971 per vissoort op basis van Quak (2016) en Hop et al (2011). $0=$ incidenteel, $+=$ minder algemeen, $++=$ algemeen, $+++=$ abundant. De tabel is beperkt tot de 16 vissoorten. $*=$ geen levensstadium meegenomen in de analyse.

\begin{tabular}{|c|c|c|c|c|}
\hline soort & stadium & soort & Quak 2016 (Tabel 5) & Hop et al 2011 (tabel 4.1) \\
\hline \multirow[t]{3}{*}{ Europese Aal } & juveniel & Anguilla anguilla & fluctuerend & \\
\hline & rode aal & & tot zeer abundant & $+++^{*}$ \\
\hline & schieraal & & fluctuerend - zeer abundant & \\
\hline \multirow[t]{2}{*}{ Bot } & juveniel & Platichthys flesus & & \\
\hline & adult & & abudant - zeer abundant & $+++*$ \\
\hline \multirow[t]{2}{*}{ Driedoornige stekelbaars } & juveniel & Gasterosteus aculeatus & & \\
\hline & adult & & & $+++^{*}$ \\
\hline \multirow[t]{2}{*}{ Dunlipharder } & juveniel & Liza ramada & & \\
\hline & adult & & & \\
\hline \multirow[t]{2}{*}{ Elft } & juveniel & Alosa alosa & zeer abundant & \\
\hline & adult & & zeer abundant & $++^{*}$ \\
\hline \multirow[t]{2}{*}{ Fint } & juveniel & Alosa fallax & zeer abundant & \\
\hline & adult & & zeer abundant & $++^{*}$ \\
\hline \multirow[t]{2}{*}{ Atlantische haring } & juveniel & Clupea harengus & zeer abundant & +++ \\
\hline & adult & & klein aantal & \\
\hline \multirow[t]{2}{*}{ Houting } & juveniel & Coregonus oxyrinchus & & \\
\hline & adult & & abudant (optrek) & ++ \\
\hline \multirow[t]{2}{*}{ Rivierprik } & juveniel & Lampetra fluviatlis & zeer abundant (optrek) & \\
\hline & adult & & waarschijnlijk zeer abundant & $+++^{*}$ \\
\hline \multirow[t]{2}{*}{ Spiering } & juveniel & Osmerus eperlanus & zeer abundant & \\
\hline & adult & & zeer abundant & $+++*$ \\
\hline \multirow[t]{2}{*}{ Sprot } & juveniel & Sprattus sprattus & & \\
\hline & adult & & & $+++*$ \\
\hline Europese steur & & Acipenser sturio & honderden & \\
\hline \multirow[t]{2}{*}{ Atlantische zalm } & juveniel & Salmo salar & zeer abundant & \\
\hline & adult & & meest abundant in mei - augustus & 0 \\
\hline Zeebaars & & Dicentrarchus labrax & & \\
\hline Zeeforel & & Salmo trutta trutta & duizenden & \\
\hline Zeeprik & & Petromyzon marinus & & \\
\hline
\end{tabular}




\subsection{Huidige situatie visstand in het Haringvliet}

Hop et al. (2016) hebben een rapport geschreven over de huidige visstand in het Haringvliet. Dit rapport geeft een schatting van de omvang van de huidige visstand, als volgt: De visstand in het Haringvliet is geschat op circa $41 \mathrm{~kg} / \mathrm{ha}$ en 361 stuks/ha. De meest voorkomende vissoort is de blankvoorn. Het grootste deel van dit bestand bestaat uit éénzomerige vis. Andere relatief veel voorkomende soorten zijn brasem, baars, snoekbaars, zwartbekgrondel en winde. Op basis van biomassa wordt het visbestand gedomineerd door brasem (57\%). Andere soorten met een relevant aandeel in de biomassa zijn snoekbaars (11\%), blankvoorn (10\%), baars, karper, paling en houting (3 tot 7\%). De grootste visbestanden in het Haringvliet bevinden zich tegen of nabij de oevers van het Haringvliet. In het open water is de omvang van het visbestand aanzienlijk kleiner, in het bijzonder in de diepe delen van het Haringvliet $(>15 \mathrm{~m})$.

\section{Fuiken monitoring}

Hetzelfde beeld van een visbestand met zoetwatersoorten volgt uit onderzoek met fuiken in het Haringvliet. Wageningen Marien Research (WMR) doet sinds 2012 (fuiken)onderzoek naar de uittrek van schieraal in vier grote uittrekpunten: de spuisluiscomplexen op het IJsselmeer (zoet), hier samengenomen als één locatie; het Noordzeekanaal (zout - brak); de Nieuwe Waterweg (zout) en het Haringvliet (zoet). Om een vergelijk te maken tussen het Haringvliet en andere uittrekpunten zijn de aantallen in de afgelopen jaren gevangen soorten opgeteld (Tabel 2). Op basis van deze vangsten wordt het (volledige) zoete karakter van het Haringvliet duidelijk. Het zoete milieu van het Haringvliet wordt duidelijk zichtbaar door de afwezigheid van de zoute soorten in de fuikvangsten (op een enkele harder en zeebaars na). Op basis van deze najaarsfuikvangsten (2012-2015) is het grootste aandeel in de fuiken: baars $(37 \%)$, snoekbaars $(25 \%)$, schieraal $(16 \%)$, blankvoorn $(15 \%)$, rode aal $(4 \%)$ en pos $(1 \%)$. Alle andere soorten $(\mathrm{N}=28)$ worden in lagere aantallen gevangen $(>0-1 \%)$.

Tabel 2 Indicatie voor de soortsamenstelling in het fuiken programma van WMR (2012-2015). Vanaf 2014 werd in het Haringvliet ook in het voorjaar gevist. Onder diadrome soorten wordt verstaan: aal, bot, driedoornige stekelbaars, elft, fint, houting, zeeforel, rivierprik, spiering, zalm, zeeprik. (Bron: WMR 2016)

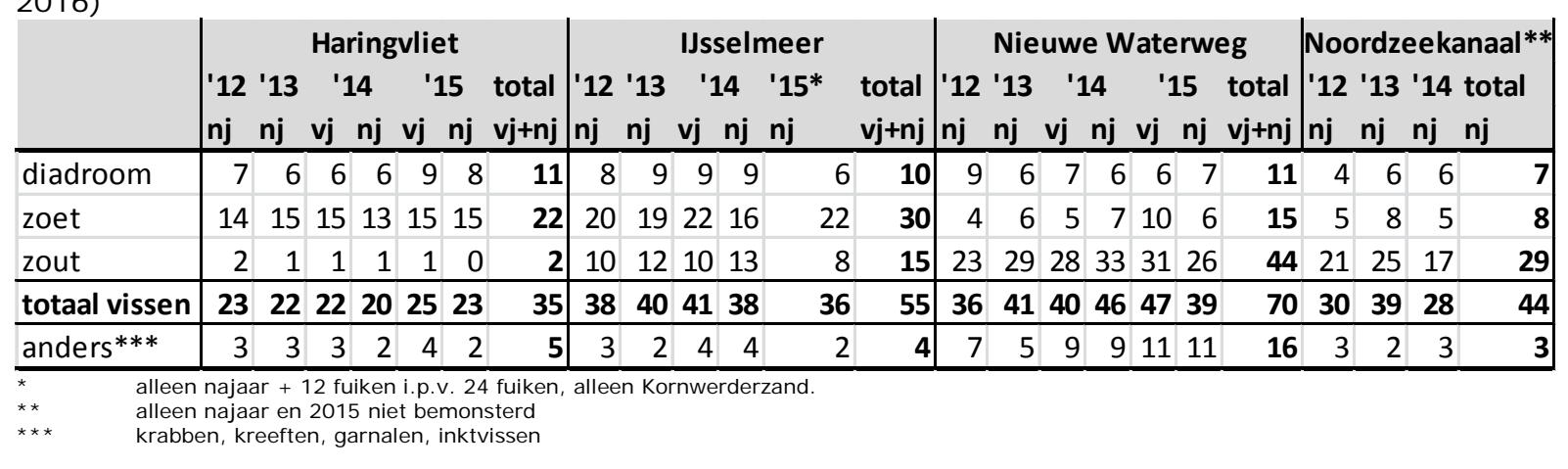

\section{Actieve monitoring}

In het Haringvliet wordt ook met een kor $^{2}$ gevist in het kader van de MWTL (Wettelijke Onderzoekstaak). Data van de visgegevens van 10 jaar monitoring (1997, 2001, 2002, 2003, 2004, 2012, 2013, 2014 en 2015) laten voor in de middenzone van het Haringvliet gemiddeld de volgende soortensamenstelling zien: brasem $(57 \%)$, snoekbaars $(21 \%)$, blankvoorn $(5 \%)$, baars $(5 \%)$, kolblei $(3 \%)$ en aal $(3 \%)$. De overige gevangen vissoorten $(\mathrm{N}=14)$ vormen per soort $>0-2 \%$ van de aantallen in de vangst.

\footnotetext{
${ }^{2}$ Een 'kor' is afgeleid van boomkor. Er wordt in de MWTL monitoring gevist met een 3 meter boomkor. Het, 3.60m lange, net wordt opengehouden door een $3.00 \mathrm{~m}$ brede boom. Aan weerszijden van de boom is een slof van 0.50 meter hoog bevestigd (Sluis et al. 2014).
} 


\section{Spuisluizen Haringvlietdam op een 'Kier' als herstelmaatregel}

\subsection{Lozingsprogramma Haringvlietsluizen (LPH 84)}

Het huidige beheer programma van de Haringvlietsluizen wordt het LozingsProgramma Haringvlietsluizen 1984 genoemd of kort gesteld LPH'84 (van Leeuwen et al., 2004). De Haringvlietsdam met daarin de 17 spuisluizen biedt bescherming tegen hoogwater van de Noordzee en zorgt er voor dat het zoute water niet binnen kan dringen in het Haringvliet. De sluizen worden beheerd om overtollig rivierwater te lozen in zee en om daarmee de waterstanden in het Benedenrivierengebied te regelen. Hierdoor wordt ook verzilting tegengehouden. Het rivierwater wordt geloosd onder vrij verval tijdens eb.

De rivierafvoer die in zee wordt geloosd via de spuisluizen van de Haringvlietdam is afhankelijk van de hoeveelheid afvoer van de Rijn zoals die gemeten wordt bij Lobith. Tot een afvoer van $1.100 \mathrm{~m}^{3} / \mathrm{s} \mathrm{gaat}^{3}$ alle afvoer van de Maas en de Rijn via de Nieuwe Waterweg. Bij een afvoer van 1.100-1.720 $\mathrm{m}^{3} / \mathrm{s}$ is de opening van de Haringvlietdam $25 \mathrm{~m}^{2}$ (1 schuif) (Vis 2017). Bij hogere afvoeren wordt de dam verder geopend tot een maximum van $6.000 \mathrm{~m}^{2}$. Vanaf $3000 \mathrm{~m}^{3} / \mathrm{s}$ worden alle 17 schuiven opengezet. Met toenemende afvoer in de Rijn bij Lobith gaat een steeds groter deel van de afvoer van de Maas en Rijn via het Haringvliet (bijvoorbeeld bij $12.000 \mathrm{~m}^{3} / \mathrm{s}$ gaat er 2/3 van de totale afvoer via het Haringvliet (Figuur 3.1).

\section{Gemiddelde jaarlijkse waterafvoer van Rijn en Maas 2000-2011}

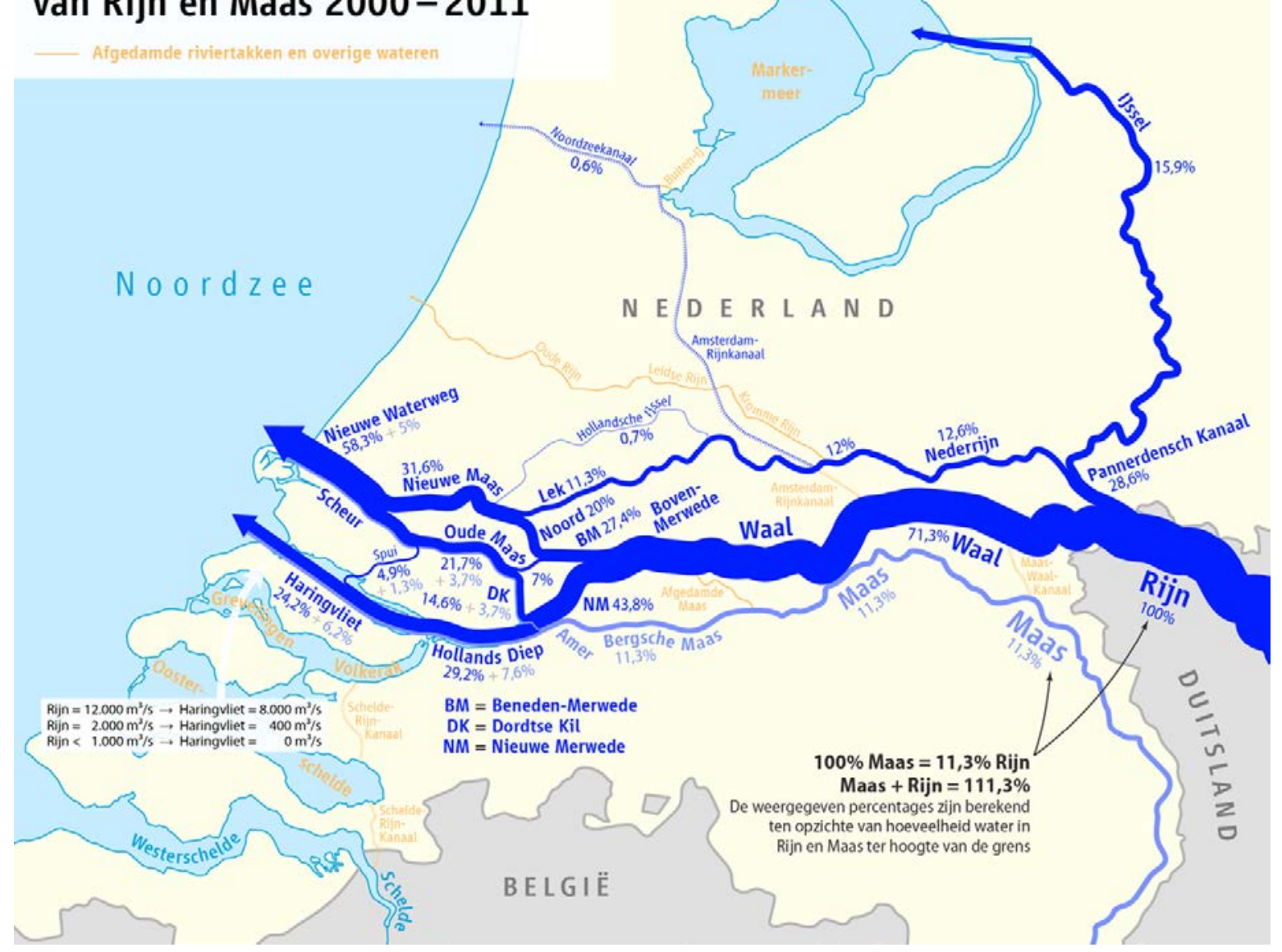

Figuur 3.1. De verdeling van de afvoer via de Rijn en Maas over de Nederlandse delta. 


\subsection{Haringvlietsluizen Operationeel Programma (HOP)}

Het nieuwe, toekomstige, beheer van de spuisluizen van de Haringvlietdam heeft als naam het "Haringvlietsluizen Operationeel Programma" (HOP). Hierbij zullen de sluizen op een "Kier" gaan. De Kier heeft tot gevolg dat er enerzijds betere intrekmogelijkheden worden gecreëerd voor vis en daarnaast ontstaat er een gebied met een brakwaterzone. Dit nieuwe beheer impliceert dat een deel van de tijd de sluizen ook (deels) geopend zullen zijn tijdens vloed. Als de afvoer bij Lobith groter is dan $1200 \mathrm{~m}^{3} / \mathrm{s}$ dan gaan de sluizen bij eb open en als de afvoer groter is dan $1500 \mathrm{~m}^{3} / \mathrm{s}$ zijn deze ook bij vloed geopend. Hierdoor ontstaat er voor het eerst sinds 2 november 1970 tijdens vloed weer een open verbinding tussen de zee en het Haringvliet. Ook in het HOP, is het sluizenbeheer afgestemd op de afvoer van de Rijn bij Lobith (Figuur 3.1). Het doel van dit nieuwe beheer is om de migratieroute van vis vanuit en naar het Rijn- en Maasstroomgebied via het Haringvliet te verbeteren.

\subsection{Kierbesluit: lerend implementeren}

Het HOP wordt stapsgewijs ingevoerd om het openen van de sluizen afgesteld te krijgen op de randvoorwaarden van behoud van zoet water, scheepvaart en hoogwaterbescherming. Daarbij zullen diverse kennisvragen beantwoord moeten worden tijdens het zogenaamde 'lerend implementeren' van de Kier (Hiddema 2014, Paalvast 2016, Noordhuis 2017). Pas wanneer de meetgegevens uit de monitoring en modelresultaten in voldoende mate met elkaar overeenkomen, wordt overgegaan op het bedieningsprogramma HOP (van Leeuwen et al., 2004). Voor het lerend implementeren wordt een periode van minimaal een jaar geraamd maar mogelijk gaat dit ook beduidend langer duren (Kier 2009, Noordhuis 2017). Op basis van de verkregen resultaten uit het lerend implementeren zal het HOP waarschijnlijk worden bijgesteld.

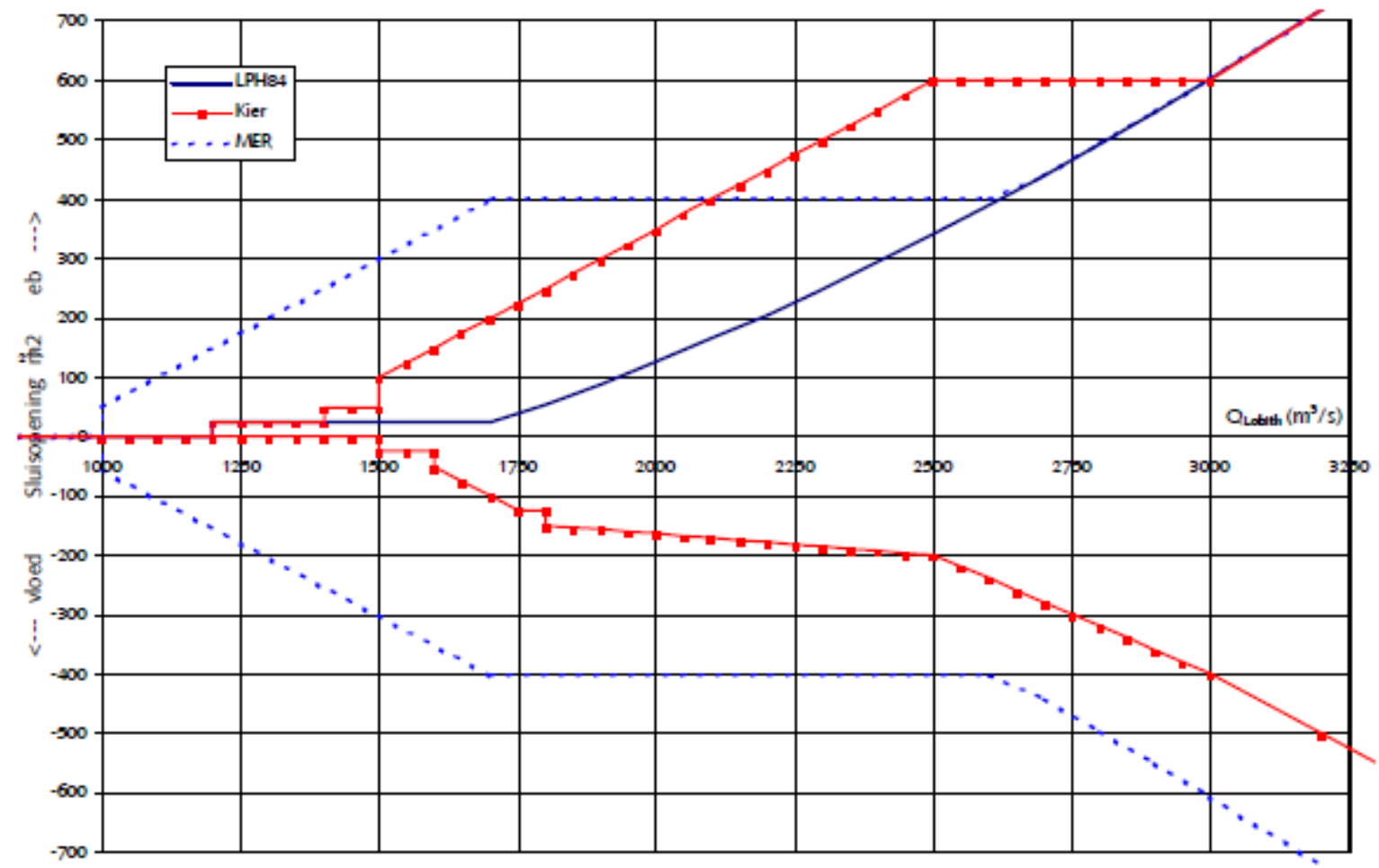

Figuur 3.2: De opening van de Haringvlietsluizen gerelateerd aan de Rijnafvoer bij Lobith. Kier beheersprogramma HOP (rood), en oorspronkelijke programma LPH84 (blauw) (Leeuwen et al. 2004).

Bij de Kier worden de sluizen vanaf een Rijnafvoer ( $Q_{b r}$ ) van $1200 \mathrm{~m}^{3} / \mathrm{s}$ bij eb geopend (Paalvast, 2016) (Figuur 3.2). Tussen een $Q_{b r}$ van $1400 \mathrm{~m}^{3} / \mathrm{s}$ en $3000 \mathrm{~m}^{3} / \mathrm{s}$ is het spui-oppervlak van de sluizen groter dan onder LPH'84. Bij rivierafvoeren groter dan $3000 \mathrm{~m}^{3} / \mathrm{s}$ zijn de sluisopeningen bij eb onder de Kier gelijk aan die van LPH'84. Vanaf een Qbr van 1500 m³/s gaan bij de Kier de sluizen ook bij vloed open. Te allen tijde is de vloed-opening kleiner dan de eb-opening. De Rijn heeft voor 50\% van de tijd een afvoer van $2200 \mathrm{~m}^{3} / \mathrm{s}$ of meer (Paalvast, 2016). 
Onderstaande lijst geeft het aantal sluisdeuren dat wordt opengezet in relatie tot de $\mathrm{Qbr}_{\mathrm{b}}$ en het doorstroom oppervlak volgens het Kierbesluit.

- Tot $1500 \mathrm{~m}^{3} / \mathrm{s}$ :

- Tot $1800 \mathrm{~m}^{3} / \mathrm{s}$ :

- Van 1800 tot $2800 \mathrm{~m}^{3} / \mathrm{s}$ :

- Van 2800 tot $3000 \mathrm{~m}^{3} / \mathrm{s}$ :

- Van 3000 tot $3600 \mathrm{~m}^{3} / \mathrm{s}$ :

- Van 3600 tot $4200 \mathrm{~m}^{3} / \mathrm{s}$ :

- Van 4200 tot $4400 \mathrm{~m}^{3} / \mathrm{s}$ :

- Groter dan $4400 \mathrm{~m}^{3} / \mathrm{s}$ :
Volledig gesloten, en huidige spuibeheer (LPH'84)

1 sluisdeur tot maximaal $123 \mathrm{~m}^{2}$

2 sluisdeuren tot maximaal $302 \mathrm{~m}^{2}$

3 sluisdeuren tot maximaal $401 \mathrm{~m}^{2}$

4 sluisdeuren tot maximaal $700 \mathrm{~m}^{2}$

5 sluisdeuren tot maximaal $900 \mathrm{~m}^{2}$

6 sluisdeuren tot maximaal $1100 \mathrm{~m}^{2}$

7 sluisdeuren tot maximaal $1200 \mathrm{~m}^{2}$

De onderstaande samenvatting (Noordhuis 2017) heeft betrekking op de effecten van het HOP. Tijdens het Lerend implementeren zullen deze effecten geleidelijk optreden in een tempo dat afhangt van de opgeroepen vragen. Hierin is de doorwerking meegenomen van de hydrologische veranderingen op de voedselbeschikbaarheid van visetende en bodemfauna etende vogels.

\section{Waterbeweging}

- $\quad$ De sluizen blijven bij eb gesloten bij een Rijnafvoer < $1100 \mathrm{~m}^{3} / \mathrm{s}$, bij vloed bij een afvoer < $1500 \mathrm{~m}^{3} / \mathrm{s}$. Daarboven worden de sluizen geopend in een mate die afhankelijk is van de Rijnafvoer.

- Op basis van afvoergegevens betekent dit dat de sluizen bij gemiddeld $88 \%$ van de eb perioden en $74 \%$ van de vloedperioden geopend zullen zijn, met een minimum van resp. $69 \%$ en $45 \%$ (vooral omstreeks oktober).

- In perioden van lage rivierafvoer kan het vooral omstreeks oktober voorkomen dat de sluizen langere tijd dicht zullen blijven. In ongeveer een derde van de jaren loopt zo'n periode op tot meer dan een maand, in de droogste jaren tot twee of drie maanden. Als zo'n periode wordt voorzien, wordt 3 dagen te voren gestopt met openen bij vloed ("zoetspoelen").

- In het Haringvliet heerst een gemiddelde getijslag van ongeveer $30 \mathrm{~cm}$, die zonder afname tot in de Biesbosch optreedt. Deze getijslag neemt met het HOP toe met slechts $3 \%$ in het westen van het Haringvliet ( $1 \mathrm{~cm}$; hoog water $2 \mathrm{~cm}$ lager, laag water $3 \mathrm{~cm}$ lager) tot $15 \%$ in de Biesbosch ( $5 \mathrm{~cm}$; hoog water $1 \mathrm{~cm}$ hoger, laag water $4 \mathrm{~cm}$ lager). Aan de buitenzijde van de sluizen neemt de huidige gemiddelde getijslag van 2,35 meter af met $6 \mathrm{~cm}$.

- Tijdens de inlaat zullen in de sluizen stroomsnelheden ontstaan in de orde van enkele meters per seconde, afhankelijk van de sluisopening. Verder weg van de sluizen zullen geen substantiële veranderingen in stroomsnelheden ontstaan.

Waterkwaliteit

- $\quad$ Bij geopende sluizen tijdens vloed dringt zout water binnen in het Haringvliet. Een deel van het zoute water blijft achter na de volgende spuigang, zodat zich vooral onder in het Haringvliet een gradiënt opbouwt. Zowel in de bovenlaag als in de onderlaag zijn de zoutgehaltes in het Haringvliet onderhevig aan getijbewegingen.

- Tijdens vloed ontstaat aan de binnenkant een mengzone waarin het zoete en zoute water verticaal wordt gemengd. Bovenin worden zoutgehalten in de orde van $1000 \mathrm{mg} / \mathrm{l}$ bereikt. Deze mengzone strekt zich één tot enkele $\mathrm{km}$ oostwaarts van de sluis uit en wordt scherp begrensd door een "plungeline". Bij eb verdwijnt deze zone weer uit het Haringvliet. Omdat de vloedperiode korter is (4 uur) dan de eb-periode ( 8 uur) bestaat deze mengzone in het Haringvliet relatief kort.

- $\quad$ Dichter bij de bodem concentreert zich zouter water dat door de hogere dichtheid onderin blijft en zich ontwikkelt tot een "dichtheidsstroom" die zich verder oostwaarts beweegt dan de mengzone, zodat oostwaarts van de plungeline gelaagdheid ontstaat met zoet water in de bovenlaag. Binnen deze dichtheidsstroom neemt het zoutgehalte oostwaarts af tot ongeveer $350 \mathrm{mg} / \mathrm{l}$ op orde grootte $10 \mathrm{~km}$ van de sluizen. Een deel van de gelaagdheid blijft bij eb in stand.

- Als bij lage Rijnafvoer het Haringvliet wordt "zoet gespoeld", wordt de bovenlaag van de waterkolom binnen een dag zoet, de onderlaag in drie tot vier dagen. Alleen in de geulen en putten beneden een diepte van ongeveer $8 \mathrm{~m}$ blijft zout achter. In de gemiddelde dagafvoer bij 
Lobith komen perioden < 1500 m3/sec gemiddeld vijf keer per jaar voor. Gemiddeld duurt zo'n periode 20 dagen, de langste periode per jaar duurt gemiddeld 49 dagen (1990-2016, exclusief zoetspoeldagen). De grootste kans op zo'n periode is in september en oktober (ca. $50 \%$ ).

- In het water aan de zeezijde (buitenzijde) van de sluizen zijn de zwevend stof gehalten, vooral in de winter, aanzienlijk hoger dan in het Haringvliet. Chlorofyl vertoont aan de buitenzijde een sterke voorjaarspiek in februari en maart, en dan zijn de concentraties hoger dan in het Haringvliet.

- Door een combinatie van sediment opwerveling door de dichtheidsstroom (zout-tong) en vlokvorming door opgeloste stoffen in zoet water in contact met zout water, kan rond het front van de zout-tong een natuurlijke troebeling optreden ("Estuarien Turbiditeits Maximum"), maar ook extra sedimentatie.

- Door de verandering in de waterverdeling over de noordelijke Delta, waarbij het aandeel spui via de Haringvlietsluizen in combinatie met de inlaat ("restdebiet") toeneemt, neemt de belasting met nutriënten op het Haringvliet iets toe.

Autonome ontwikkelingen sinds de MER van 1998

- Het fosfaatgehalte in het Haringvliet was in de periode van de MER relatief stabiel, maar is daarna verder afgenomen tot ongeveer $0,08 \mathrm{mg} / \mathrm{l}$, ruim binnen de achtergrond range voor een zoetwatergetijden rivier.

- Chlorofyl was lange tijd stabiel maar is na de MER periode met bijna een factor drie afgenomen.

- Zwevend stof concentraties waren in de MER periode verhoogd, maar zijn sindsdien gehalveerd.

- Het doorzicht bedroeg in de MER periode in de zomer gemiddeld ongeveer $1 \mathrm{~m}$, daarna nam het toe tot $1,5-2 \mathrm{~m}$.

- Twee belangrijke exoten hebben sinds de MER periode het Haringvliet gekoloniseerd: de Quaggamossel sinds 2005, de Zwartbekgrondel sinds ongeveer 2012.

- Monitoringsgegevens van MWTL suggereren zowel binnen het Haringvliet (boomkor) als buiten de sluizen (fuikbemonsteringen "Haringvliet estuarium") een forse afname van de visbestanden, in het estuarium onder meer van sprot.

Betekenis voor natuurwaarden

- De visgemeenschap zal profiteren van een geleidelijke zout-zoet gradiënt in het Haringvliet in combinatie met getij-gebonden inlaat. Niet alleen de intrekmogelijkheden verbeteren daardoor sterk, ook het uitspoelen van zoetwatervis vermindert doordat die zich door de westwaarts oplopende zoutgehalten oostelijker zal ophouden.

- Visintrek kan worden gehinderd in perioden met lage rivierafvoeren. Doordat de langste periode waarin geen water wordt ingeladen, die tot drie maanden kan duren, gemiddeld in de periode september tot november optreedt, worden vooral soorten die dan naar binnen willen ${ }^{3}$ getroffen, waaronder Schar, Schol, Wijting en Sprot.

- Zoete bodemfauna (Quaggamossel) zal in het westen verdwijnen door de zoutindringing, die zich concentreert in de onderlaag. Zoute of brakke macrofauna zal zich moeilijk kunnen handhaven door de vaak langdurige zoetspoelperioden, afgezien van de diepere geulen en putten (>8 $\mathrm{m}$ diep). De noodzaak van het zoetspoelen zou tijdens het lerend implementeren moeten worden onderzocht met het zo weinig mogelijk zoetspoelen als vertrekpunt. Zoetspoelen zou betekenen dat het voordeel van de inlaat van zout water voor visetende vogels (zie hieronder) wegvalt. Tevens zou het betekenen dat zich geen zoute bodemfauna noch zoete kan handhaven in de onderlaag. De effecten van zoetspoelen op de voedselketen zijn nauwelijks te voorspellen.

- Sterns zullen profiteren van de intrek van vis en van de mengzone van brak water die zich tijdens vloed een paar uur lang binnen de sluizen (tot maximaal $3 \mathrm{~km}$ ) ontwikkelt, totdat vanaf half juli de kans op te lage rivierafvoeren toeneemt.

- Viseters kunnen profiteren van nieuwe doorzicht gradiënten die zich rond de mengzone en door opwerveling en uitvlokking bij de top van de zout-tong kunnen ontwikkelen.

- Duikende viseters kunnen profiteren van de vis onder de spronglaag in de zouttong

- Steltlopers zullen hooguit in de Biesbosch kunnen profiteren van enige toename van de getijslag.

\footnotetext{
${ }^{3}$ Schat, schol, wijting en sprot hebben geen directe baat bij een intrek op het Haringvliet. Deze soorten zijn voor hun paai en opgroei niet direct afhankelijk van een trek richting het zoete water of estuarium.
} 
- Watervogels die van bodemfauna leven zullen nauwelijks worden beïnvloed omdat de gebieden die brak worden grotendeels te diep zijn om in te foerageren.

\subsubsection{Migratievensters Kier: dynamiek in tijd en ruimte}

Met het geplande beheer van de spuisluizen van de Haringvlietdam (de Kier) ontstaat dus weer een opening tussen de zee en het Haringvliet over de loop van een volledige getijdencyclus. De Kier is echter niet permanent geopend, de opening is afhankelijk gesteld in het beheer van de spuisluizen van de Haringvlietdam van de afvoer van de Rijn bij Lobith. Op basis van historische gegevens over de rivierafvoer is een inschatting te maken over de waarschijnlijkheid dat de Kier geopend is. Over de periode 1901-2010 is weergegeven wanneer de Kier bij vloed volledige gesloten zou zijn $\left(<1500 \mathrm{~m}^{3} / \mathrm{sec}\right.$ afvoer) en wanneer deze open zou zijn geweest volgens het HOP (Figuur 3.2).

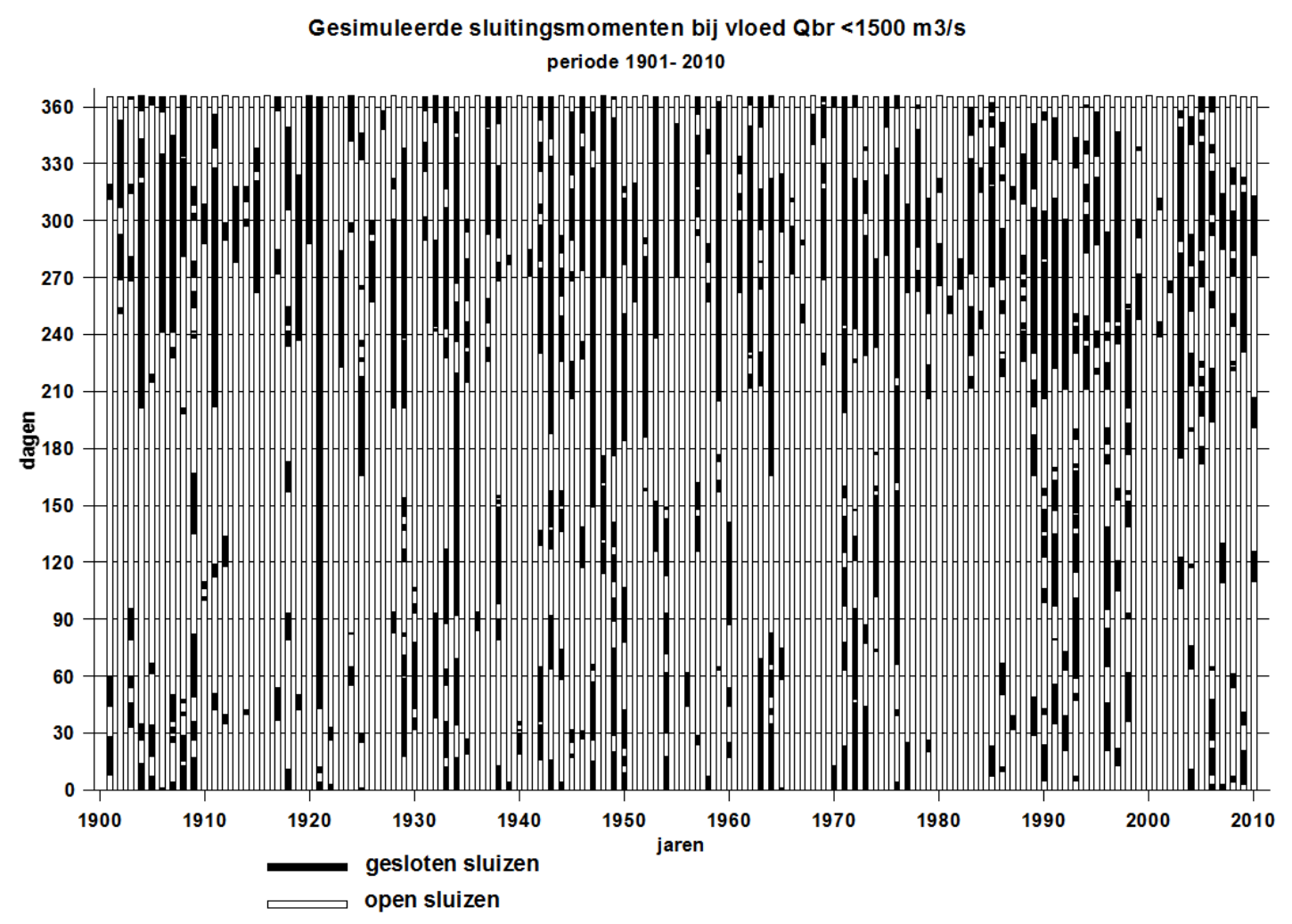

Figuur 3.2: Simulatie van de perioden van sluiting van de sluizen bij vloed op basis van de rivierafvoer bij Lobith van minder dan $<1500 \mathrm{~m}^{3} / \mathrm{s}$ (Paalvast, 2016).

De dagafvoer is gemiddeld 5 keer per jaar lager dan $1500 \mathrm{~m}^{3} / \mathrm{s}$, met een gemiddelde duur van 20 dagen. De langste periode duurt gemiddeld 49 dagen (Noordhuis, 2017).

Voor de migratie van vis is echter niet alleen het openen of sluiten van de spuisluizen van belang, ook de grootte van de totale spuiopening is van belang (zie paragraaf 4.3). Hiervoor zijn de dagelijkse afvoeren in 1989-2014 gekoppeld aan de 8 opties voor het aantal sluisdeuren dat volgens het Kierbesluit opengezet zou zijn (zie paragraaf 3.3). De frequentieverdeling van deze 8 opties op elke dag van het jaar in de periode 1989-2014 wordt weergegeven in Figuur. 3.3 . In de periode augustus tot en met oktober is de kans groot dat de spuiopening dicht is, waarbij een volledige opening van de Kier in deze periode maar heel af en toe voor zal komen (optie 0 of 1 ). Terwijl in de periode eind december tot begin februari in meer dan de helft van het aantal jaren de Kier in zijn geheel op zou staan (optie 7). 


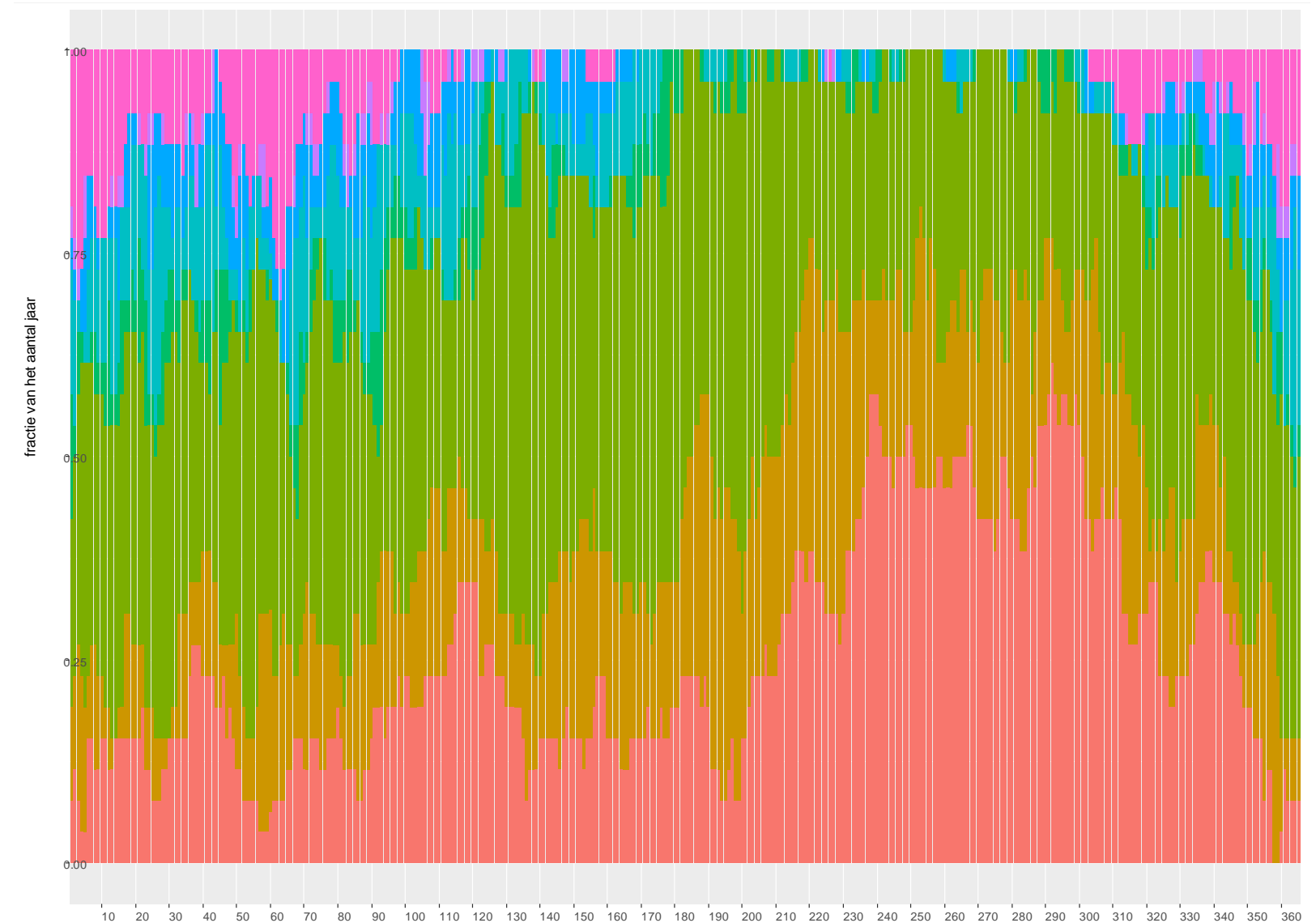

Dag-afvoer van de Rijn, openzetten van de Kier dag van het jaar
tot $1500 \mathrm{~m} 3 / \mathrm{s}$, sluisdeur volledig gesloten
$1500-1800 \mathrm{~m} 3 / \mathrm{s}, 1$ sluisdeut tot maximaal $123 \mathrm{~m} 2$
$1800-2800 \mathrm{~m} 3 / \mathrm{s}, 2$ sluisdeuren tot maximaal $302 \mathrm{~m} 2$
2800-3000 m3/s, 3 sluisdeuren tot maximaal $401 \mathrm{~m} 2$
3000-3600 m3/s, 4 sluisdeuren tot maximaal $700 \mathrm{~m} 2$
$3600-4200 \mathrm{~m} 3 / \mathrm{s}, 5$ sluisdeuren tot maximaal $900 \mathrm{~m} 2$
4200-4400 m3/s, 6 sluisdeuren tot maximaal $1100 \mathrm{~m} 2$
$>4400 \mathrm{~m} 3 / \mathrm{s}, 7$ sluisdeuren tot maximaal $1200 \mathrm{~m} 2$

Figuur 3.3: Openstelling van de sluizen in de Haringvlietdam zoals die gegeven de dag-afvoer van de Rijn volgens het Kierbesluit zou hebben plaatsgevonden in de periode 1989-2014. Per dag van het jaar wordt het aantal dagen voor elk van de 8 openstellingsopties weergegeven (uitgedrukt als fractie van het totaal aantal dagen per datum in de periode 1989-2014 (26)). De 8 openstellingsopties zijn $0=$ volledig gesloten, $1=1$ sluisdeur tot maximaal $123 \mathrm{~m}^{2}, 2=2$ sluisdeuren tot maximaal $302 \mathrm{~m}^{2}, 3=3$ sluisdeuren tot maximaal $401 \mathrm{~m}^{2}, 4=4$ sluisdeuren tot maximaal $700 \mathrm{~m}^{2}, 5=5$ sluisdeuren tot maximaal $900 \mathrm{~m}^{2}, 6=6$ sluisdeuren tot maximaal $1100 \mathrm{~m}^{2}, 7=7$ sluisdeuren tot maximaal $1200 \mathrm{~m}^{2}$.

Het openen van de Kier beoogt herstel van de vismigratieroute. Het HOP leidt echter niet tot een natuurlijke estuariene situatie in het Haringvliet. Juist in de periode dat in de natuurlijke situatie het zoute water het verste landinwaarts trekt, als de rivierafvoer laag is dus met name in de periode september-oktober, wordt de Kier gesloten en is de kans groot dat de migratieroute voor langere periode geblokkeerd wordt. Naast de blokkade van de migratieroute heeft dit ook effect op de zoutgehalten in het Haringvliet. 


\subsubsection{Dynamiek in habitats rondom de Haringvlietdam}

Met de Kier zal gecontroleerd zout water in het Haringvliet komen. Dit is met name gunstig voor de vissen die met een getijde stroming het Haringvliet op willen zwemmen. Echter, de getijdeslag in het Haringvliet wijzigt nauwelijks en blijft dus zeer beperkt (Noordhuis 2017), waardoor een zoetwatergetijde gebied zich niet kan ontwikkelen.

De zoute invloed verandert de samenstelling van het water in het voorheen volledig zoete Haringvliet. Hoe groot de schommelingen in zoutgehalte worden, of hoever het zoute water oostwaarts zal reiken en of het een continue of variabel proces is, is vooralsnog niet duidelijk mede door het begrip 'lerend implementeren'. In het Kierbesluit is vastgelegd dat de zoutindringing niet verder mag reiken dan de lijn Spui-Middelharnis, welke op ongeveer $11 \mathrm{~km}$ van de Haringvlietdam af ligt. Het lerend implementeren moet resulteren in een aangepast beheer programma dat hier voor zorgt. Echter, in een natuurlijk estuarium is de 'zoutindringing' sterk afhankelijk van de afvoer van een rivier en de getijdeslag in het systeem (Figuur 3.4).

a)
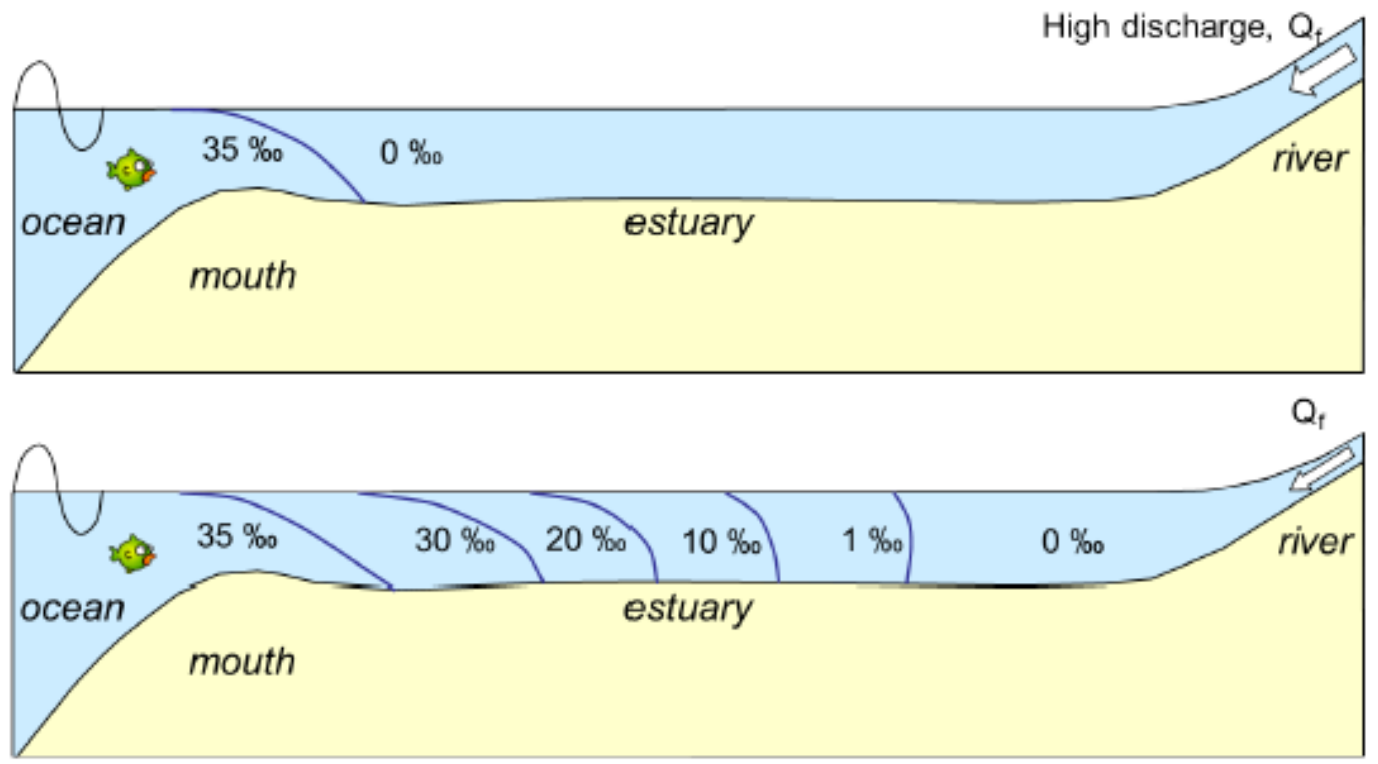

c)

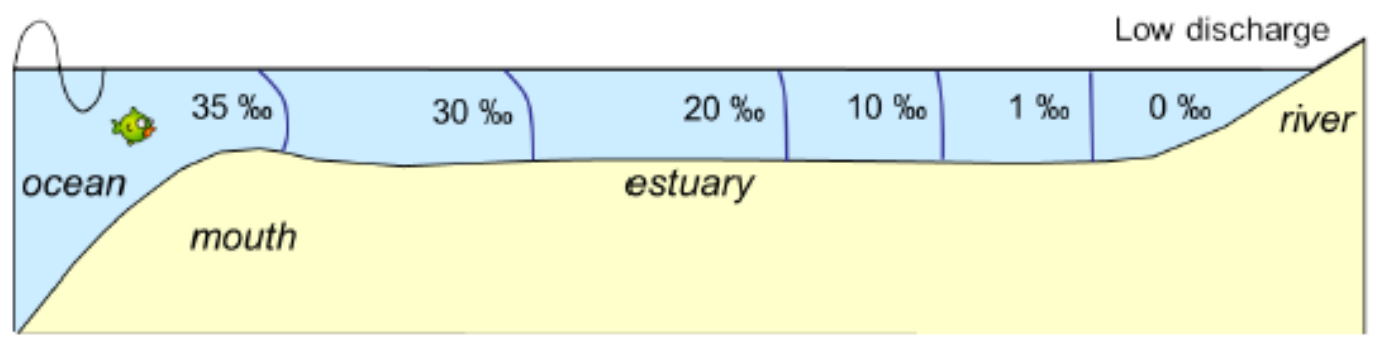

Figuur 3.4 Model weergave van de longitudinale verspreiding van het zoutgehalte (saliniteit) in een (a) gestratificeerd estuarium, (b) gedeeltelijk gemixte en (c) goed gemixt estuarium (Savenije 2012).

De instroom van zout water zorgt er niet voor dat het Haringvliet geheel zout of brak wordt, dat is in een natuurlijk estuarium ook nooit het geval (Figuur 3.4). Het zoute water verdeelt zich nooit evenredig over een estuarium. Menging van het zoute en zoete water zal met een Kier en de bestaande structuren dan ook beperkt van omvang zijn ( Jacobs et al. 2003). Menging vindt alleen dicht bij de sluizen plaatst, waarna het zoutere water uitzakt naar de bodem en als dichtheidsstroom verder landinwaarts trekt (Figuur 3.5). Hoever de mengzone en ook de bodemstroom zich landinwaarts zullen verplaatsen is hoofdzakelijk afhankelijk van de grootte van de rivierafvoer, de opening van de sluizen en hoe de opening wordt verdeeld over het sluizencomplex. Bovendien zal bij hoge rivierafvoer (boven de 2200 $\mathrm{m} 3 / \mathrm{s}$ ) de brakwater mengzone zich vooral aan de zeezijde van de Haringvlietdam bevinden en niet zozeer aan de zijde van het Haringvliet. Paalvast (2016) geeft een model van saliniteit bij diverse Rijnafvoeren, en op basis van dit model wordt duidelijk dat het ook mogelijk is dat bij hoge afvoeren en bij eb de monding van de Voordelta tot de kop van Goeree (van de Haringvliet dam westwaarts tot circa een $10 \mathrm{~km}$ in zee) zoet water bevat. 


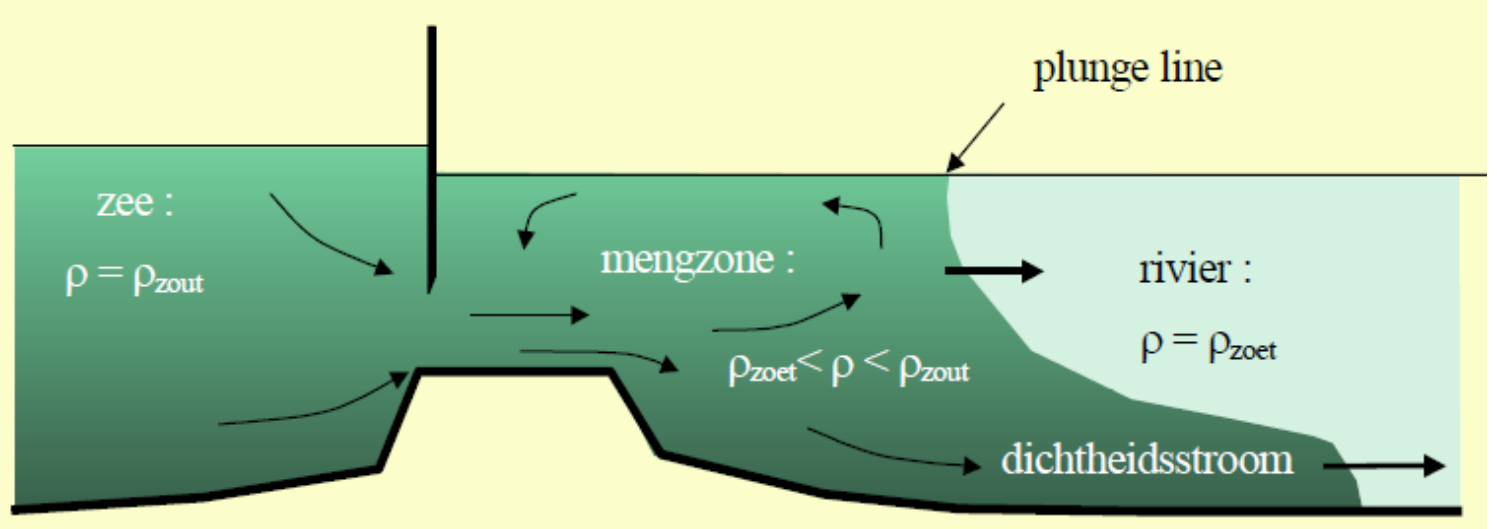

Figuur 3.5: Schematische weergave van de verwachte passage van zeewater door de Haringvlietsluizen (uit Jacobs et al 2003).

Daarnaast is de verblijftijd van zout (of brak) water in het Haringvliet erg variabel en sterk afhankelijk van het actuele beheerprogramma. Een deel van het zoute/brakke water zal het Haringvliet met spuien weer verlaten. De bovenlaag van het Haringvliet kan bij spuien al na een dag weer zoet zijn ( $\mathrm{J}$ acobs et al. 2003), waarna het nog een dag of 3 tot 4 duurt voordat ook de onderlaag weer zoet is. Echter, het is onwaarschijnlijk dat al het zoute of brakke water het Haringvliet geheel zal verlaten, de diepste putten en met name die nabij de Haringvlietdam zullen waarschijnlijk voor langere periode zout water blijven bevatten (Figuur 3.6).

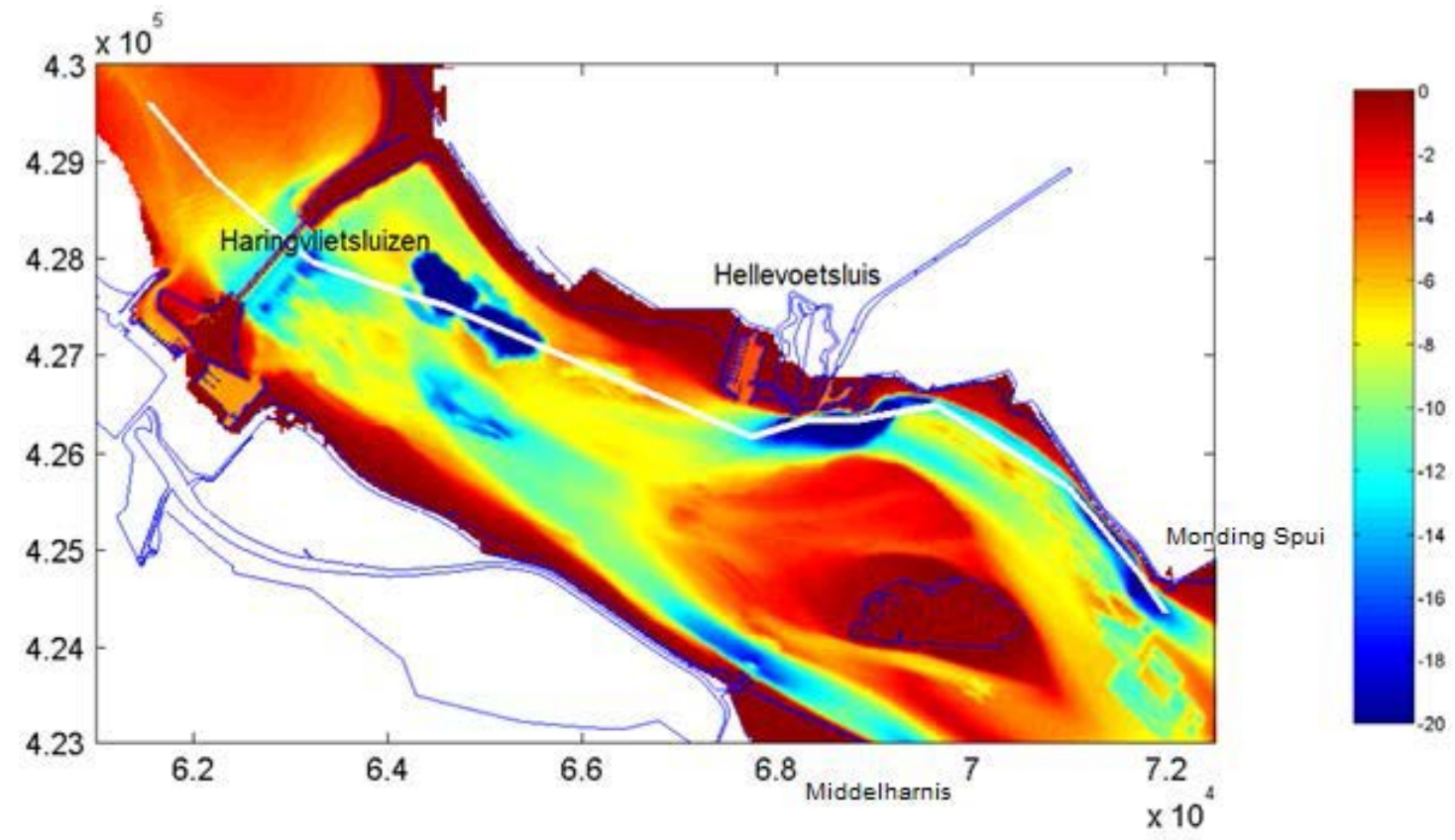

Figuur 3.6: Dieptekaart van het Haringvliet (Jacobs et al. 2003).

Met het geplande beheer van de spuisluizen en afhankelijk van de rivierafvoer zal er niet per se alleen in het Haringvliet maar mogelijk ook in de Voordelta, dus rondom de Haringvlietdam, een zoet-zout gradiënt ontstaan. Het huidige zoete Haringvliet wordt gedurende bepaalde perioden in het jaar zouter, waarbij de gehele waterkolom alleen zout zal zijn dicht bij de sluizen en op verder afstand van de dam in het Haringvliet het zoute water zich vooral bij de bodem bevind. In perioden met lage rivierafvoer zal er mogelijk alleen zout/brak water aanwezig zijn in de diepe putten nabij de Haringvlietdam (Figuur 3.6), terwijl in periodes van lange sluiting van de Kier het gehele Haringvliet weer zoet wordt. De zones beneden de gemiddelde diepte van $8 \mathrm{~m}$ geven de onderlaag aan van het zout(ere) water, deze lagen zullen alleen gemengd en uitgespoeld worden bij hoge afvoer (Noordhuis 2017). Het kan maanden duren voordat deze zoute onderlaag zoet wordt (Groeneboom et al. 2016). 


\subsection{Zoetspoelen}

De Kier levert een zone op waarmee de huidige harde zoet-zout overgang bij de Haringvlietdam in principe tot het verleden behoort onder normale Rijn afvoer. Echter, bij droge perioden voert de Rijn te weinig water om het brakwater te kunnen weren voorbij de lijn ten oosten van de lijn Middelharnis-Spui en voorafgaand aan dergelijke laagwater perioden zal het Haringvliet worden "zoetgespoeld" om het brakke water geheel te verwijderen uit het Haringvliet, waarna de sluisdeuren gesloten worden.

Bij het zoetspoelen wordt geen zeewater meer in het Haringvliet ingelaten door de sluizen niet meer te openen bij vloed. Vervolgens wordt gedurende een aantal dagen gespuid bij eb om zoveel mogelijk zoutwater uit het Haringvliet weg te spoelen. De perioden van zoetspoelen zullen naar verwachting het meest voorkomen in de maanden september-oktober. Daarom zal telkens met het zoetspoelen tijdelijk de zoet-zout overgang rondom de Haringvlietdam ook weer verdwijnen. Een zoetgespoeld Haringvliet kan per jaar een 90 dagen aaneengesloten optreden, zoals dit is gebaseerd op 100 jaar metingen van Rijnafvoer (Paalvast, 2016). Dit geeft een contrast met de natuurlijke situatie waarbij juist in droge perioden het zoute water het verst landinwaarts trekt. 


\section{De Kier als herstelmaatregel voor vissen}

\subsection{Nederland als delta van grote rivieren}

De Rijn, Maas en Schelde stromen via de delta in zuidwestelijk Nederland naar zee. Een relatief klein deel van de afvoer van de Rijn stroomt via de IJ ssel en het IJsselmeer. Nederland is zodoende een belangrijke toegangspoort voor riviertrekvissen die deze grote stroomgebieden (tot in Duitsland, België en Frankrijk) gebruiken om te paaien en/of daar ook op te groeien. Het Haringvliet en de Nieuwe Waterweg zijn de twee belangrijkste routes voor trekvissen die het achterland in het Maas- en Rijnstroomgebied gebruiken (Figuur 4.1).

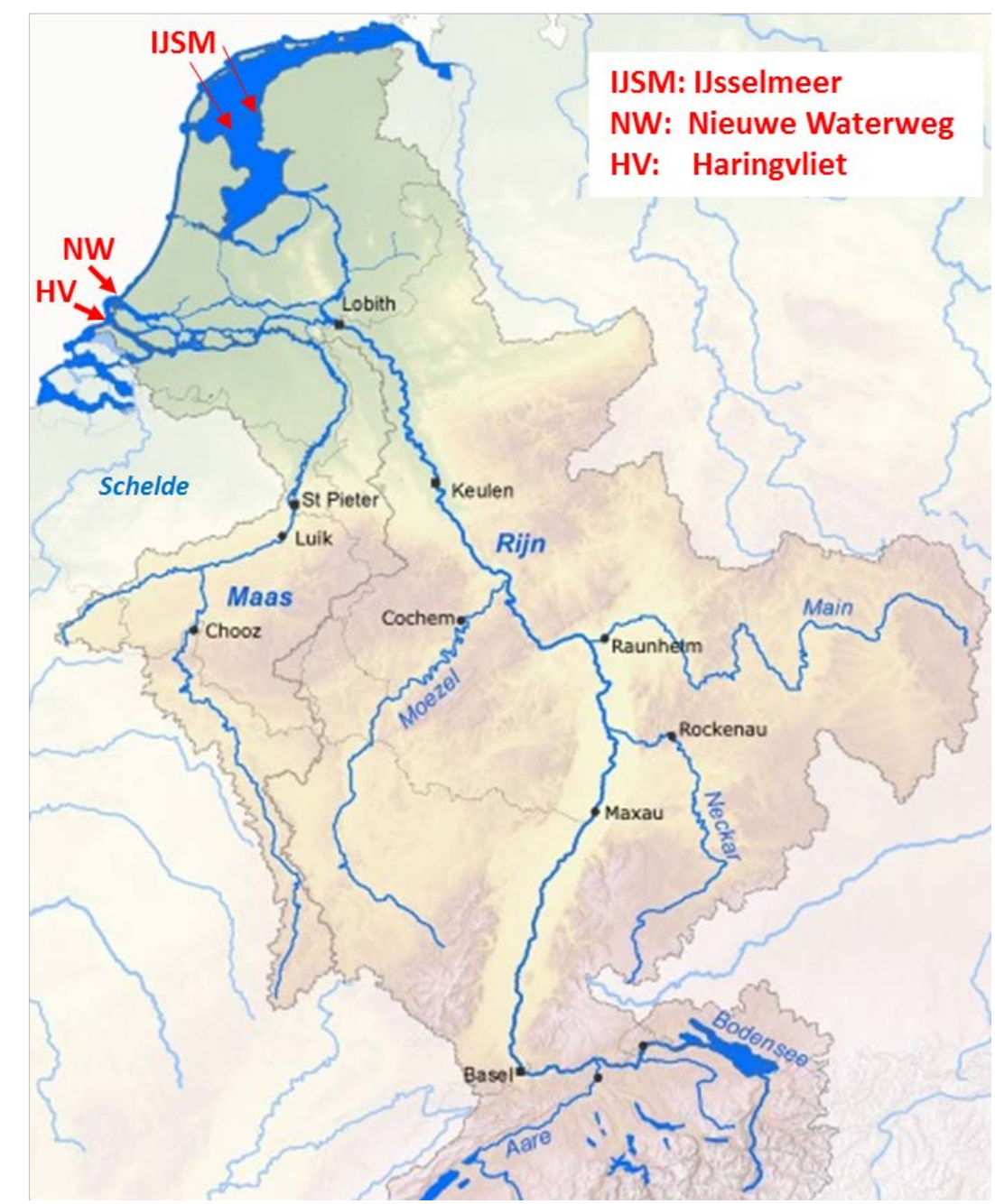

Figuur 4.1. De stroomgebieden van de Rijn en Maas, waarbij het Haringvliet en Nieuwe Waterweg de belangrijkste in- en uitgangen vormen. 


\subsection{Haringvlietdam als corridor: potentiële migratieroutes langs het sluizencomplex in de Haringvlietdam}

Vissen die vanuit de Noordzee de Rijn en de Maas op willen trekken via het Haringvliet kunnen in potentie drie routes nemen: (1) de 17 spuisluizen, (2) de zes visriolen van de Haringvlietdam of (3) via de nabij de Haringvlietdam gelegen scheepvaartsluis bij Stellendam (Figuur 4.2). Daarnaast is het ook mogelijk voor trekvissen zoals de zalm of de zeeforel om via de Nieuwe Waterweg of wellicht zelfs via de Afsluitdijk hun opgroei- of paaigronden te bereiken.

De eerste (1) route gaat via de spuisluizen (Figuur 4.2, blauwe pijlen en Figuur 4.3). Dit is de route met de sterkste waterstromen en onder het huidige beheer (LPH '84) zijn de stroomsnelheden een sterk beperkende factor voor visintrek. Met de Kier zal de migratie via de spuisluizen mogelijk verbeteren en worden de spuisluizen een verbeterde migratie route van de Noordzee naar Rijn en Maas. Onder het huidige beheer ( $\mathrm{LPH}$ 84) stroomt de rivierafvoer altijd in de richting van de Noordzee (Voordelta). Vissen hebben de keuze op welk moment zij zich aandienen binnen het spuivenster, maar zullen altijd tegen de stroom in moeten zwemmen. Passage door de spuisluizen kan - in het algemeen - zowel aan het einde en het begin van een spuivenster plaatsvinden (Vis and Spierts 2010, Griffioen et al. 2014). Maar over het algemeen is er slechts in beperkte mate inzicht over de passeerbaarheid van de spuisluizen en dus ook van de Haringvlietdam, behalve de onderzoeken naar zeeforel waar in de periode 1996-2000 505 zeeforellen bij de Haringvlietdam zijn gevangen en gezenderd. Van deze groep zijn er 70 landinwaarts gedetecteerd in het Haringvliet $\left(14 \%{ }^{4}\right), 99$ in de Nieuwe Waterweg $(20 \%), 2$ op het IJ sselmeer $(<1 \%)$ en van 5 zeeforellen $(1 \%)$ is het onbekend of zij via de Nieuwe Waterweg of het Haringvliet zijn gezwommen ( $\mathrm{Bij}$ de Vaate et al. 2003). Dit soort kennis is geheel niet beschikbaar voor kleine diadrome vissen. Verder blijkt uit fuikenmonitoring dat andere soorten zoals zalm, zeeprik, houting en rivierprik ook het Haringvliet opzwemmen (Keeken et al. 2016), maar niet hoe en of dit alleen via de spuisluizen is, wanneer zij dit doen of in welke mate.

De tweede route (2) om de Haringvlietdam te kunnen passeren in de stroomopwaartse richting van de Voordelta naar het Haringvliet vormen de visriolen (Figuur 4.3). Deze zes visriolen, die fungeren als schutsluizen (pijlers 1, 4, 7, 10, 13 en 16) zijn doorgaans alleen in bedrijf gedurende afgaand water waardoor er geen zoutwater wordt ingelaten. De sluizen werken volgens schuttingen totdat er $12 \mathrm{~cm}$ peil verschil is tussen het Haringvliet en de Voordelta. De schuiven aan de rivierzijde worden $10 \mathrm{~cm}$ opengezet om een lokstroom te creëren, hierbij staat de zeeschuif open. Na 45 minuten gaat de zeeschuif dicht en gaat de rivierschuif 30 minuten geheel open. De vis wordt zo geschut op het moment dat er gespuid wordt. In de periode 1 maart - 1 juni geldt t.b.v. glasaal intrek een ander regime waarbij er zout water het Haringvliet wordt ingelaten. Dit gebeurt volgens hetzelfde protocol (ingesteld vanaf 1990) waarbij ook met vloed wordt geschut. Dit water wordt middels "zoutriolen" weer afgevoerd wanneer het water in de Voordelta $25 \mathrm{~cm}$ lager staat dan in het Haringvliet (Vis 2017).

\footnotetext{
${ }^{4}$ Bij zeeforel is niet vast te stellen of zij ook daadwerkelijk gemotiveerd zijn om de rivier op te trekken voor paai of foerageer gedrag. Om een intrek effcientie te bepalen is het daarom beter om te spreken van $\geq 14 \%$ voor het Haringvliet. Tevens blijkt voor zeeforel dat zij ook de Nieuwe Waterweg (of zelfs het IJsselmeer) kunnen benutten voor de intrek. De intrek moet daarom in werkelijkheid breder worden gezien dan alleen via de Haringvlietdam.
} 


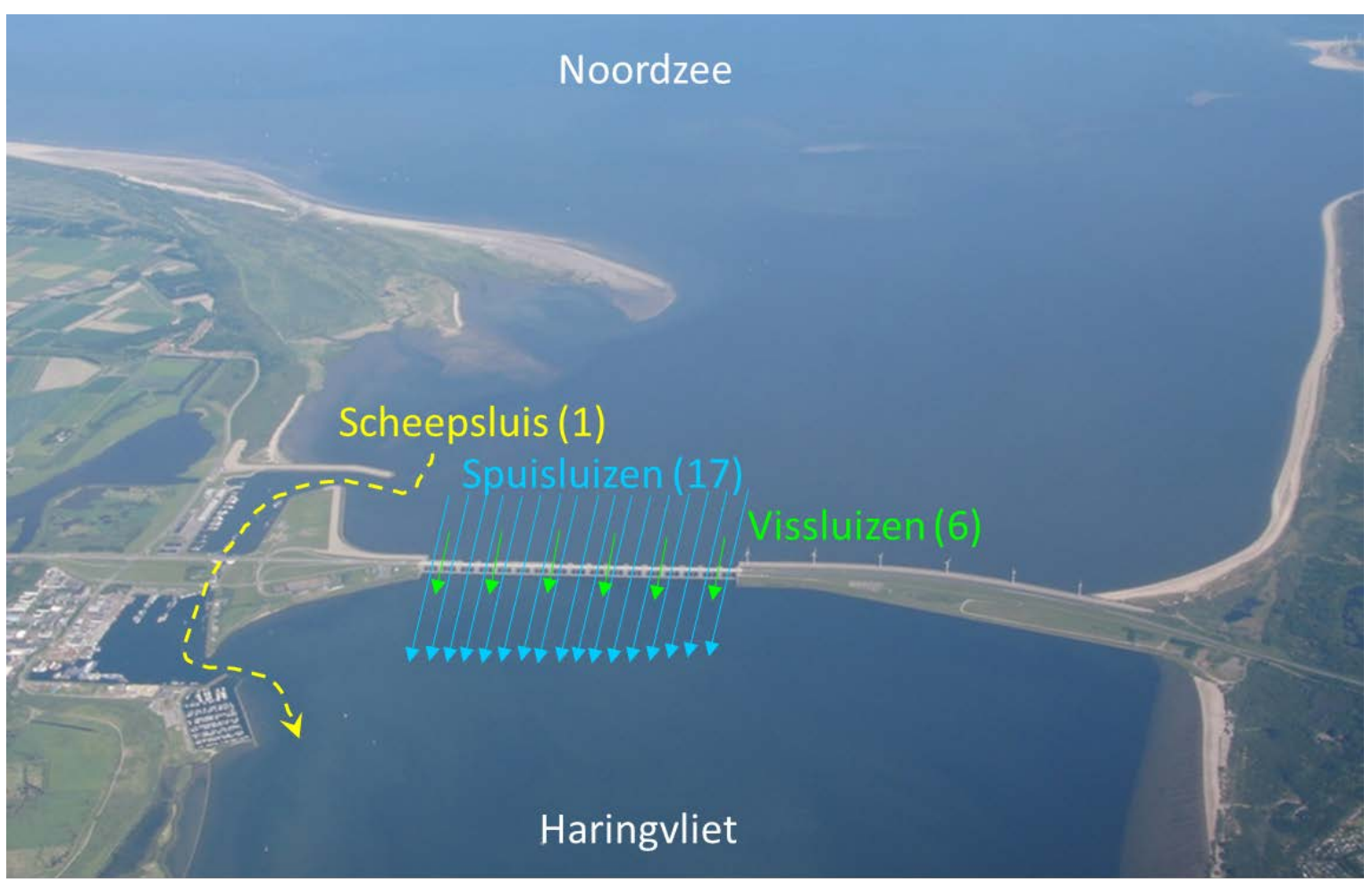

Figuur 4.2 De drie potentiële routes die migrerende vis in stroomopwaartse richting kunnen gebruiken om vanuit de Voordelta het Haringvliet te bereiken. 1 = de scheepsluizen van Stellendam gelegen aan de zuidzijde van het complex. 2 = de spuisluizen en 3 de visriolen.

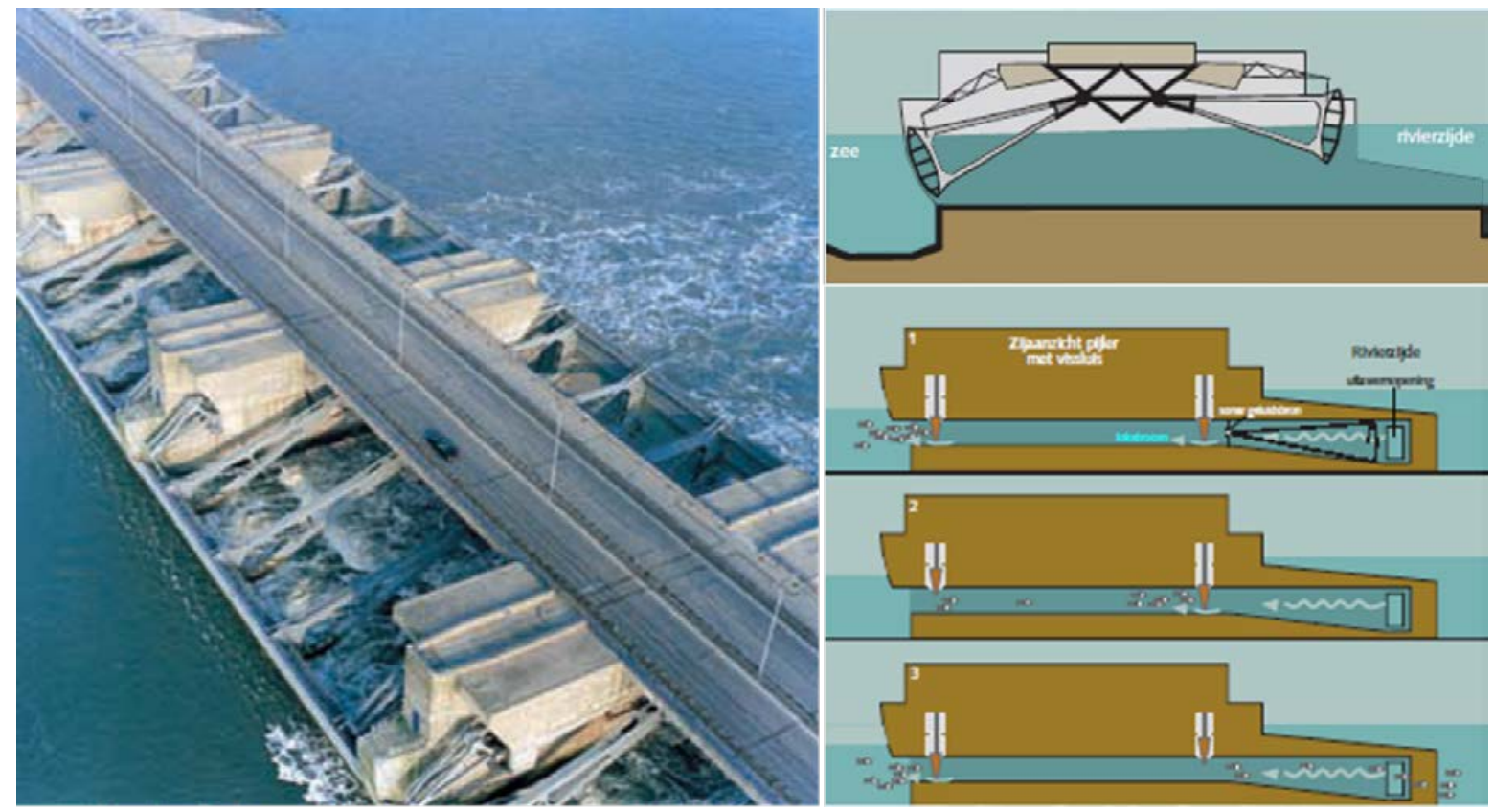

Figuur 4.3 Een bovenaanzicht (links) van de schuiven en (rechtsboven) een dwarsdoorsnede van de schuiven aan de zeezijde en de rivierzijde. Daarnaast in de pijlers 1, 4, 7, 10, 13 en 16 zogenoemde vissluizen die middels 'schuttingen' vissen inlaten (rechtsonder).

De derde (3) route gaat via de scheepsluis, gelegen tussen de binnen en buitenhaven van Stellendam (Figuur 4.2, gele pijlen). Uit een recente telemetrie studie is gebleken dat ook via de Haringvlietdam uitgespoelde snoekbaarzen gebruik maken van de scheepssluis om terug te zwemmen naar het Haringvliet (Vis 2017). Dat vissen gebruik maken van scheepssluizen in het algemeen is (beperkt) bekend, maar niet in welke mate en hoe succesvol zij hierin zijn (Griffioen et al. 2013, Wolfshaar et al. 2015). Bij afnemende rivierafvoeren bestaat in de buitenhaven van Stellendam een zoetwaterbel waarin de uitgespoelde zoetwatervissen zich wat langer op kunnen houden. Wel is er (met name relevant voor diadrome soorten) bij de spuisluizen van de Haringvlietdam een grote lokstroom aanwezig welke per definitie een grotere reikwijdte en in potentie een grotere aantrekkende werking hebben op migrerende vis. Hierover is met betrekking tot het Haringvliet niets bekend. Echter, een soortgelijke situatie is wel bekend bij de Afsluitdijk met zenderonderzoek (zeeprik, zeeforel en houting). Gezenderde vissen werden 
eerder teruggevonden bij de spuikom dan dat ze werden gedetecteerd bij de scheepsluizen waaruit blijkt dat zij zich waarschijnlijk eerder aangetrokken voelden door de grote lokstroom vanuit de spuisluizen (Griffioen et al. 2014). Ook uit fuikvangsten, die echter in de regel onderling slecht te vergelijken zijn, blijkt dat er relatief meer vissen worden gevangen bij de spuikom in vergelijking met de scheepssluizen (Griffioen 2014). Hoe dit voor het Haringvliet geldt is vooralsnog onbekend. Echter, het is zeer aannemelijk dat de grootste aantrekkende werking op vis de spuisluizen zullen zijn door de afvoer van (zoet) water).

\subsection{Passagemogelijkheden van de spuisluizen met De Kier}

De passage mogelijkheden voor vis via de spuisluizen zullen met de Kier worden vergroot. Met de Kier wordt zeewater beperkt ingelaten gedurende vloed in het Haringvliet. Naast dat het venster in de tijd wordt verruimd, en gedurende een langere tijd vissen heen en weer door de Haringvlietdam kunnen zwemmen, wordt het ook makkelijker voor passieve migranten om met de stroom mee richting het Haringvliet te zwemmen/driften. Om vooral de (relatief) minder mobiele, kleine en vaak juveniele vissoorten zoals glasaal, bot en driedoornige stekelbaars een duidelijke (herkenbare) ingang aan te geven moet bij het beheer van de spuisluizen ook rekening gehouden worden met welke spuisluizen wordt gespuid (bij eb) en met welke wordt gekierd (bij vloed), en bij voorkeur zijn dit dezelfde sluizen. Een succesvolle passage van zee naar Haringvliet heeft logischerwijs een grotere kans van slagen als een vis zich al in de nabijheid bevindt van de voor het Kieren te gebruiken sluis. Daardoor zou deze vis, voordat de Kier opengaat, gelokt kunnen worden door voorafgaande afvoer van zoet water. Omdat het "Kieren", ten opzichte van spuien een kleiner volume en dus een kleinere reikwijdte heeft (Figuur 4.4), is het raadzaam om het spuien en het "Kieren" bij dezelfde schuiven plaats te laten vinden. Op deze manier is het zoete water wat wordt gespuid tevens een lokstroom voor de Kier. Indien de sluizen waarmee gespuid en 'gekierd' wordt ver uit elkaar zouden liggen, is het niet ondenkbaar dat vissen worden misleidt door de grotere lokstroom van het spuien, en zich verzamelen voor een dichte deur (Figuur 4.4 rechts).

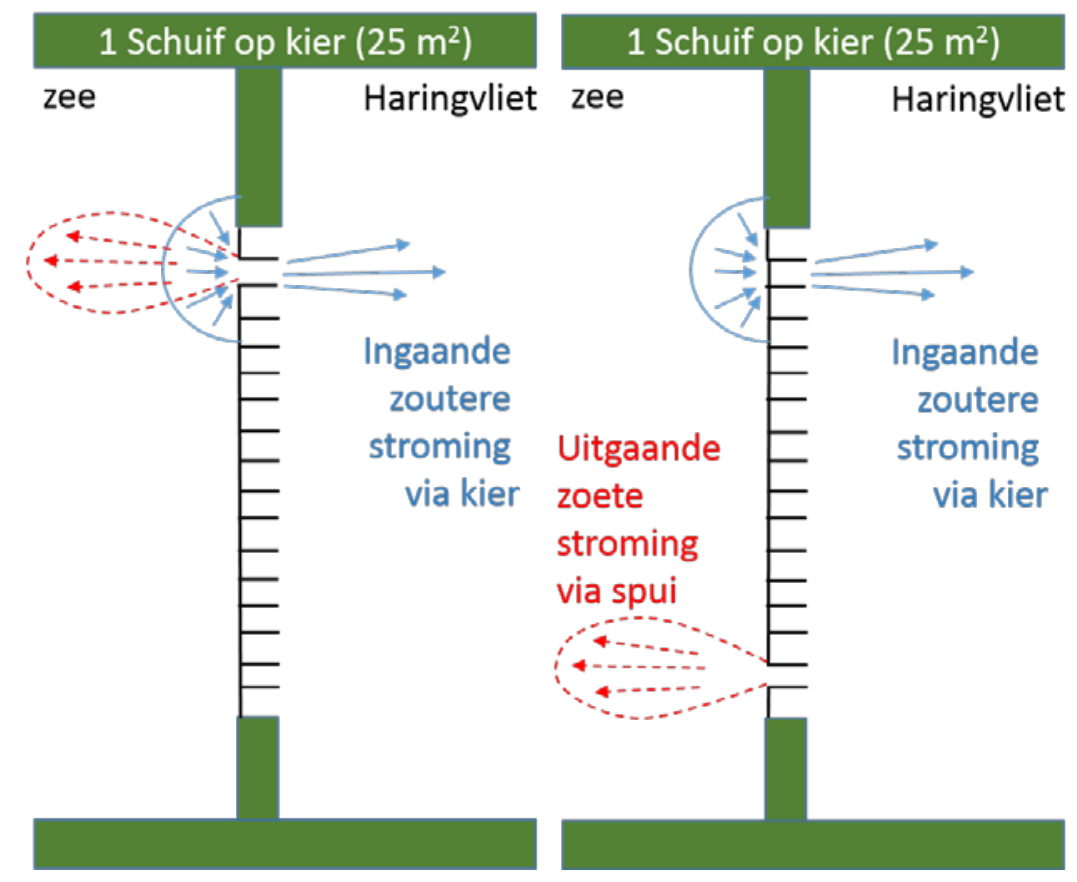

Figuur 4.4: De opening van de Haringvlietsluizen waarbij 1 schuif open staat. In het linker scenario wordt zowel gespuid als "gekierd" met dezelfde schuif. Deze optie heeft de voorkeur omdat hierdoor kleine juveniele vis gelokt wordt naar de juiste sluis die benut gaat worden tijdens het kieren en de doorgang biedt van zee naar het Haringvliet. In het rechter scenario vind het spuien zuidelijk plaats en het "Kieren" noordelijk waardoor minder mobiele vis zich verzamelt voor een sluis die bij kieren gesloten zal zijn.

Wanneer het spuien middels meerdere schuiven plaatsvindt (zeven of meer), dan is de zoete lokstroom groter waardoor de reikwijdte van de vindbaarheid van deze opening voor de aanwezige trekvissen aanzienlijk wordt vergroot (Figuur 4.5). Echter, in deze situatie is het ook mogelijk dat kleinere (passieve) migranten hinder ondervinden van het spuien en deze kunnen zelfs worden uitgespoeld. 


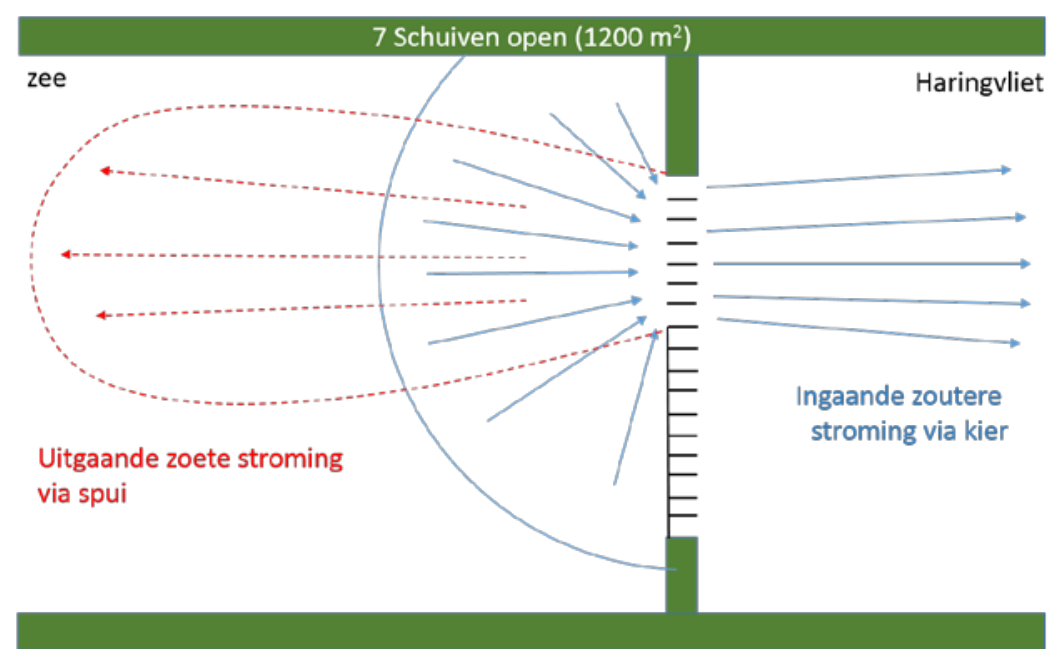

Figuur 4.5: De Haringvlietsluizen bij een opening met 7 schuiven.

Voor een succesvolle passage van zwakke zwemmers via de Kier in de Haringvlietdam is het noodzakelijk dat deze vissen zich kunnen handhaven in de Voordelta. Dat impliceert dat deze na het spuien snel kunnen terugkeren richting de schuiven. Daarvoor moeten zij zich vooraf kunnen positioneren nabij de sluizen waarmee gekierd gaat worden, door zich te oriënteren op basis van de spuistroom (Figuur 4.6, rode of groene stippen). Echter, indien vissen zich pal voor de schuiven verzamelen is het risico van wegspoelen (verder de zee op, gele stippen Figuur 4.6) groot, en dat geeft dit telkens door opnieuw spuien een volledige 'reset' van de situatie, waarna de vissen hun weg opnieuw zullen moeten vinden (rode stippen Figuur 4.7). De groene stippen in Figuur 4.6 geven aan dat indien een deel van de vissen zich ook ten noorden en ten zuiden van de Haringvlietdam verzamelen deze ook weer snel gebruik kunnen maken van het kieren.

Tijdens het spuien zullen vissen die fysiek in staat zijn om tegen de stroom in te zwemmen het Haringvliet bereiken. Via de Kier kan er zowel actief of passief met de stroom mee of tegen de stroom in (actief) richting het Haringvliet worden gezwommen.

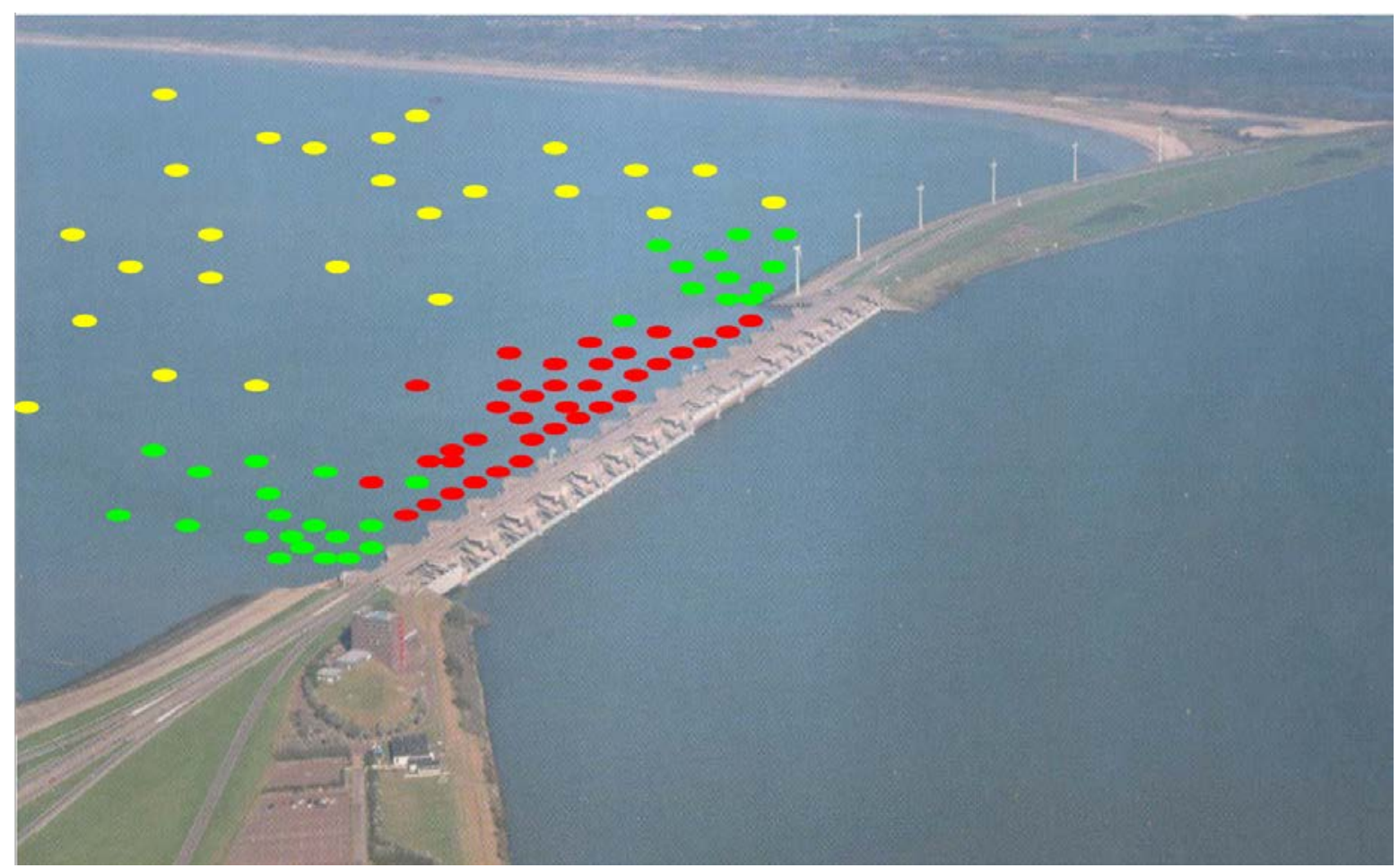

Figuur 4.6: Hypothetisch scenario waarbij de positionering van (zwakke) zwemmers t.o.v. de Haringvlietsluizen zijn weergegeven. Geel = zogenaamde wegspoelers die tijdens het spuien niet tegen de stroom in kunnen zwemmen. Rood = vissen die op zoetwater (lek?)stroom afkomen en zich 
geconcentreerd verzamelen voor de dam (risico op volledige reset van de situatie indien er gespuid wordt). Groen = vissen die aan de zijkanten van de dam zijn en na het spuien vrijwel direct weer positie kunnen innemen of gebruik kunnen maken van een migratie mogelijkheid.

Naast dat vissen het Haringvliet op willen zwemmen, worden er met het spuien onbedoeld ook zoetwatervissen uitgespoeld. Een deel van deze vissen kunnen ook weer terugkeren is gebleken uit recent onderzoek van VisAdvies (Vis 2017) waarbij grote snoekbaarzen werden gevolgd met behulp van zenders. Echter, over het algemeen is er weinig bekend over het uitspoelen van zoetwater vis. In het verleden is hier bij het Haringvliet onderzoek naar gedaan met sonar en werd de voorzichtige conclusie getrokken dat dagelijks duizenden kilo's naar zee worden gespoeld (Kemper 1997).

\subsection{Effect van de Kier op (1) diadrome soorten}

Diadroom (o.a. driedoornige stekelbaars, fint, elft, zalm) is een verzamelterm voor katadroom (voortplanting in zout water, leefgebied in zoet water) en anadroom (voortplanting in zoet water, leefgebied in zout water). Voor de voltooiing van hun levenscyclus zijn diadrome soorten sterk afhankelijk van een succesvolle stroomopwaartse migratie en daarom is de komst van de Kier belangrijk voor juist die soorten. Voor diadrome vissen die via de Haringvlietdam naar de stroomopwaarts gelegen paaigronden of opgroeigebieden zwemmen is een snelle schakeling van zout naar zoet waarschijnlijk fysiek geen probleem. Toch is de kennis over de nodige omvang van acclimatisatie zones (zoet-zout overgangen), inclusief de tijd die diadrome soorten daarin moeten verblijven voordat zij door kunnen zwemmen, zeer beperkt aanwezig in de literatuur (Winter et al. 2014). Overigens worden de diadrome soorten van de Rijn en de Maas riviersystemen allemaal individueel besproken in hoofdstuk 5 .

\subsection{Effect van de Kier op (2) estuariene residente soorten}

Estuariene residente soorten (o.a. slakdolf, brakwatergrondel, harnasman) kunnen hun hele leven in de estuaria verblijven en zijn hier sterk op aangewezen (van der Molen 2012). De vissen in dit gilde kunnen in principe baat hebben bij een herstel van de natuurlijke zoet-zout gradiënt in een estuarium, zoals het Haringvliet. Echter, door het (ook met het geplande beheer van de spuisluizen) ontbreken van een permanent aanwezige zoet-zout gradiënt in het Haringvliet en de Voordelta zullen de estuarien residente soorten zich zeer waarschijnlijk niet blijvend kunnen vestigen en zal er geen sprake zijn van populatie opbouw van de soorten binnen dit gilde in het Haringvliet. Vermoedelijk zullen deze soorten de kleine brakwater habitats in de diepere putten als refugia kunnen benutten. Echter, in hoeverre deze diepe putten met brakwater goed vindbaar zijn en of deze daadwerkelijk benut kunnen worden is nog onbekend. Het ziet er vooralsnog naar uit dat voor enige mogelijk herstel van dit gilde in het Haringvliet een verdergaand herstel van het continue karakter van een functionerend estuarium nodig zal zijn.

\subsection{Effect van de Kier op (3) mariene juveniele soorten}

Mariene juveniele soorten (o.a. haring, schar, schol, tong, wijting) gebruiken een type O2 overgangswater als kinderkamer (van der Molen 2012). Echter, voor de meeste mariene juveniele soorten zullen, naar verwachting, de zoutgehalten in het Haringvliet na de Kier te laag zijn om veel extra opgroeihabitat op te leveren. Alleen soorten met een hoge tolerantie voor lage zoutgehalten zoals haring en sprot zullen kunnen profiteren van het extra opgroeigebied, ook al zal dit type leefgebied zeker niet permanent voorhanden zijn, zoals gedurende perioden met weinig rivierafvoer en gesloten sluizen.

Uiteraard zullen met de Kier niet alleen mariene juveniele soorten in het Haringvliet terecht komen, ook volwassen zeevissen zoals harder, haring, sprot en zeebaars zullen met het zoute/brakke water een plek vinden in het Haringvliet. Deze soorten worden in hoofdstuk 5 individueel besproken.

Zeevissen die, actief of passief in het Haringvliet terecht komen zullen daar een beperkt ruimtelijk gebied met zoutwater aantreffen dat deels bestaat uit de mengzone, deels uit de aan de bodem gebonden dichtheidstroom, en enkele zoute putten. Voor zeevissen die goed tegen water met een laag zoutgehalte kunnen, is het onwaarschijnlijk dat zowel de mengzone, de aan de bodem gebonden dichtheidsstroom, 
of de zoutwater putten, voldoende leefruimte bieden om voor langere tijd in het Haringvliet te verblijven. Daarnaast bestaat de kans dat zeevissen 'gevangen' worden in een volledig zoet Haringvliet wanneer de sluizen worden gesloten voor langere tijd na het zoetspoelen. Deze zeevissen zullen een volledig zoet of tijdelijk brak systeem vermoedelijk niet kunnen overleven. Een vergelijkbare situatie bestaat op het IJ sselmeer waar enorme aantallen jonge haring voor de spuisluisdeuren ophopen om naar binnen te zwemmen (Griffioen et al. 2014). Het lot van deze haringen is onbekend, maar aangenomen wordt dat sterfte onvermijdelijk is indien zij niet met een volgende spuivenster weer naar buiten worden gespoeld. Overigens staan zowel het Noordzeekanaal als de Nieuwe Waterweg in (nagenoeg) open verbinding met zee. In deze waterlichamen komen veel zoutwatersoorten voor (Tabel 2). Op het Noordzeekanaal loopt een "zoutwatertong" over de bodem van het kanaal, tot diep in het systeem door (tot in de haven van Amsterdam) waardoor de overlevingskansen voor zoutwatervissen toenemen. Zo zijn bijvoorbeeld in de fuikenmonitoring van WMR op het Noordzeekanaal zelfs soorten als hondshaai en congeraal aangetroffen (Keeken et al. 2016).

Toch zijn sommige soorten zeevissen wel degelijk in staat om zich aan te passen aan een lagere saliniteit, maar veelal hebben deze soorten een gerichte migratie richting foerageer- (harder, zeebaars, zeeforel) of paai- of opgroeigebieden (diadrome soorten). Aanpassing aan een nieuwe saliniteit kan gepaard gaan met een hoog energieverbruik en een daarbij passende verlaagde conditie (Komoroske et al. 2016).

\subsection{Effect van de Kier op (4) seizoensgasten}

Deze mariene soorten (o.a. diklipharder, geep, snotolf, sprot) gebruiken de estuaria om te paaien of te foerageren (van der Molen 2012). Hun aanwezigheid in het estuarium is vaak van korte duur en afhankelijk van gunstige omstandigheden (voedselaanbod of seizoensgebonden omgevingsfactoren). Voor deze soortengroep geldt dat de verwachte zoutgehalten in het Haringvliet na de Kier toch te laag zullen zijn om veel geschikt foerageerhabitat op te leveren. Slechts die soorten met een tolerantie voor lage zoutgehalten, zoals dunlipharder ${ }^{5}$ en zeebaars ${ }^{6}$, zullen kunnen profiteren van extra foerageergebied in het Haringvliet. Daarbij moet worden opgemerkt dat dit gebied niet permanent voorhanden zal zijn, zeker niet in perioden met weinig rivierafvoer en een gesloten Kier. De overige, voor lagere zoutgehalten minder tolerante seizoensgasten zullen naar verwachting niet of nauwelijks kunnen profiteren van de Kier.

\subsection{Effect van de Kier op (5) zoetwatersoorten}

Zoetwatersoorten (o.a. snoekbaars, baars, blankvoorn, brasem) verblijven regelmatig in de oligohaliene zone, bijvoorbeeld om daar te foerageren (van der Molen 2012). Binnen de KRW zijn zoetwatersoorten in een overgangswater (O2) een indicator voor de locatie van de overgangszone van zoet naar zout water. De toekomstige instroom van zout water zal uiteraard het milieu veranderen in het huidige, volledig zoete Haringvliet. Het zal echter afhangen van de zouttolerantie en de bewegingsmogelijk van de zoetwatersoorten als wel van de uiteindelijke verblijfsduur en verspreiding van het zout in hoeverre de zoetwatersoorten hier mee om kunnen gaan. Zoetwatervis in het Haringvliet kan zich stroomopwaarts bewegen, en zal dit doen al naar gelang de saliniteitgrens en fysieke capaciteit. Indien zij in 'volledig' zout water worden 'gevangen' doordat zij uitspoelen met het spuien, of indien het indringende zoute water hen overvalt en zij niet meer instaat zijn hieraan te ontsnappen, dan zullen zij waarschijnlijk sterven als gevolg van het zoute milieu. Onder het huidige beheer van de Haringvlietdam wordt veel zoetwatervis uitgespoeld met een voorzichtige schatting van enkele duizenden kilo's per dag bij gemiddelde rivierafvoer (Kemper 1997). Zoetwatervis die in zee uitspoelt en niet meer terug kan zwemmen zal sterven door uitdroging en vergiftiging door het zout.

Dat niet alle uitgespoelde zoetwatervis in de Voordelta daar achterblijft en sterft in zeewater blijkt uit een onderzoek met akoestische telemetrie, gehouden in 2016-2017 met snoekbaars bij de

\footnotetext{
${ }^{5}$ Wordt officieel voor de KRW ingedeeld in de Diadrome vissen

${ }^{6}$ Wordt officieel voor de KRW ingedeeld in de Marien Juveniele
} 
Haringvlietdam (Vis 2017). In totaal werden 67 snoekbaarzen ingezet om het terugkeer gedrag te evalueren vanuit de Voordelta naar het Haringvliet. Zes snoekbaarzen werden tussentijds gerapporteerd na een fuikvangst aan de zeezijde van het Haringvliet en deze werden daar ook weer levend losgelaten. In totaal wisten elf snoekbaarzen de Haringvlietdam stroomopwaarts te passeren. Zij deden dit deels via de visriolen $(n=9)$ en deels via de scheepvaartsluis van Stellendam $(n=2)$, maar stroomopwaartse passage door de Haringvlietdam werd niet waargenomen via de spuisluizen.

Door de Kier ontstaat een meer geleidelijke zoet-zout gradiënt in het Haringvliet waardoor (naar verwachting) minder zoetwatervissen dichter tot de sluisdeuren zullen naderen, en hierdoor zullen zij minder snel naar zee uitspoelen (Noordhuis 2017). Daarnaast neemt de kans door instelling van de Kier voor zoetwatervis die dan toch nog uitspoelt toe om met het opvolgende inkomend tij weer naar binnen te trekken (Vis 2017). Uitspoeling kan ook onder het geplande management van de sluisdeuren nog optreden, bijvoorbeeld in perioden met hogere afvoer wanneer de zoet-zout gradiënt zich grotendeels aan de zeezijde van de Haringvlietdam bevindt. Overigens zullen logischerwijze zoetwatervissen niet uitspoelen in perioden waarin de Kier niet open staat en na het zoetspoelen zullen deze hier dan ook geen hinder van ondervinden. 


\section{Prognose herstel trekvis populaties}

\subsection{Vismigratie kalender Droomfonds}

Op basis van vigerend beleid (KRW en Natura 2000) zijn doelsoorten aangewezen voor het Haringvliet en de Voordelta. Daarnaast zijn uit de beschreven diverse gilden (Hoofdstuk 4) enkele soorten uitgekozen door 'het project haringvliet' die representatief zijn voor die gilden. De selectie van soorten vormen in totaal zestien relevante soorten, exemplarisch voor herstel van het Haringvliet. Deze 16 soorten zijn eerder gepubliceerd in de "vismigratie kalender" (Figuur 5.1) van project Haringvliet. Het gaat hierbij hoofdzakelijk om diadrome vissen. Deze zijn zeer kwetsbaar voor migratiebarrières en zullen deels zelfs tot op populatieniveau kunnen profiteren van de komst van de Kier.

\section{Vismigratiekalender Haringvliet}

\begin{tabular}{|c|c|}
\hline 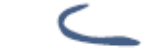 & $\begin{array}{l}\text { Aal/Palling } \\
\text { Anoullib aloum }\end{array}$ \\
\hline & $\begin{array}{l}\text { Bot } \\
\text { platictethys nosus }\end{array}$ \\
\hline & $\begin{array}{l}\text { Driedoornige } \\
\text { stekelbaars } \\
\text { Gasterostous scwlostus }\end{array}$ \\
\hline & $\begin{array}{l}\text { Dunlipharder } \\
\text { Lza ramada }\end{array}$ \\
\hline & $\begin{array}{l}\text { Elft } \\
\text { Alosa alosa }\end{array}$ \\
\hline & $\begin{array}{l}\text { Fint } \\
\text { Alosa tallax }\end{array}$ \\
\hline & $\begin{array}{l}\text { Atlantische } \\
\text { Haring } \\
\text { Cupos harengus }\end{array}$ \\
\hline & $\begin{array}{l}\text { Houting } \\
\text { consgonus aprinchus }\end{array}$ \\
\hline & $\begin{array}{l}\text { Rivierprik } \\
\text { Lampotra fuviatiss }\end{array}$ \\
\hline & $\begin{array}{l}\text { Splering } \\
\text { Osmerus operianus }\end{array}$ \\
\hline & $\begin{array}{l}\text { Sprot } \\
\text { sprattus spratus }\end{array}$ \\
\hline & $\begin{array}{l}\text { Europese } \\
\text { steur } \\
\text { Aclponser sturio }\end{array}$ \\
\hline & $\begin{array}{l}\text { Atlantische } \\
\text { Zaim } \\
\text { saimo salor }\end{array}$ \\
\hline & $\begin{array}{l}\text { Zeebaaars } \\
\text { Decentrarchus abrax }\end{array}$ \\
\hline & $\begin{array}{l}\text { Zeeforel } \\
\text { saimo trutta trutta }\end{array}$ \\
\hline & $\begin{array}{l}\text { Zeeprilk } \\
\text { Potramyzon marinus }\end{array}$ \\
\hline
\end{tabular}

Figuur 5.1: De 16 (www.haringvliet.nu).

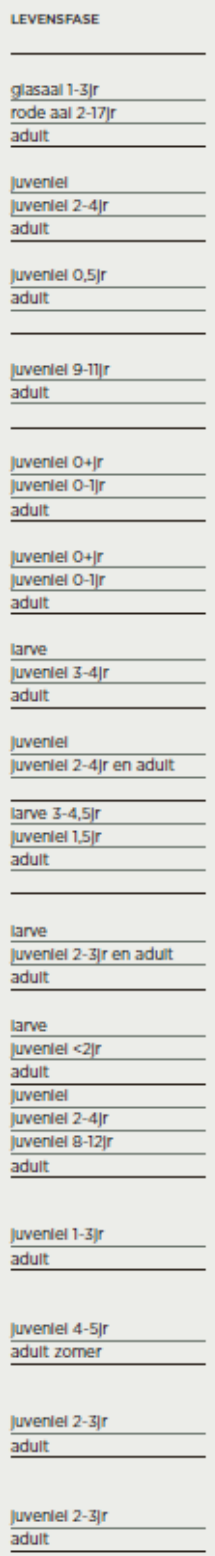

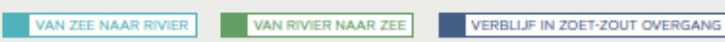

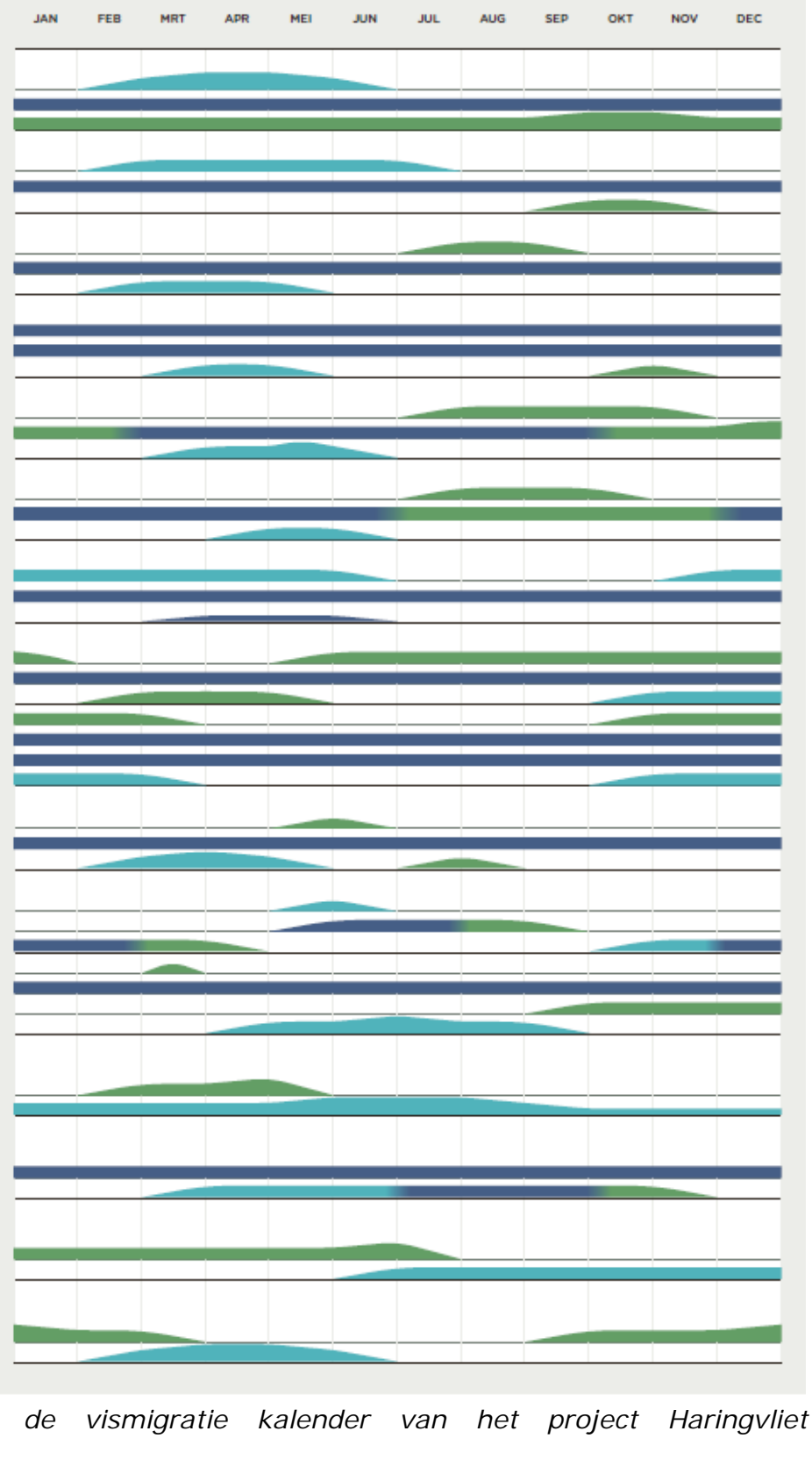
vissoorten van de vismigratie kalender van het project Haringvliet 
Het nut van een estuarium als het Haringvliet verschilt per diadrome soort. Sommige soorten gebruiken estuaria alleen om tussen de zeefase en rivierfase heen en weer te kunnen trekken. Voor een soort als de Atlantische zalm, zeeprik en rivierprik (Figuur 5.2 links boven), moet de nagenoeg volledige populatie tussen zee en rivieren kunnen migreren. Voor deze soorten is de corridorfunctie voor de gehele populatie van groot belang. Voor deze soorten geldt dat het belang van een corridorfunctie van het estuarium zeer hoog is, maar daarentegen is het habitat gebruik van het estuarium nauwelijks van belang.

Een soort waarbij zowel de corridorfunctie als het habitat in estuaria van belang is, is de fint (Figuur 5.2 rechtsboven). Deze soort stelt zeer hoge eisen aan zowel de corridor-functie (passeerbaarheid) van estuaria als aan de habitat functie. De fint gebruikt de getijdedynamiek in een estuarium om succesvol te kunnen paaien en op te groeien als larve, waarna de jonge en volwassen finten een veel breder spectrum aan kusthabitats kunnen benutten. Met name voor een bijdrage aan de populatie van de fint is daarom meer nodig dan 'alleen' een kier.

Het belang van de corridor- en habitat functie voor de 16 doelsoorten van deze rapportage, en of de gehele populatie dan wel en deel daarvan hierbij betrokken is, is weergegeven in Figuur 5.2. Voor soorten als sprot, zeebaars en dunlipharder, die hun heel levenscyclus ook in zout water kunnen voltooien maar die wel brakke/zoetere habitats kunnen benutten voor foerageren, zal slechts een (klein) deel van de populatie gebruik maken van de corridor- en habitat functie van estuaria (Figuur 5.2 links onder). Ook voor de Atlantische haring geldt een zelfde redenering, maar is bekend dat een deel van de populatie estuaria opzoekt met name in een juveniel stadium. Soorten als spiering, driedoornige stekelbaars, houting en bot is zowel een corridor als de habitat functie van het estuarium van belang, maar deze soorten kunnen (ook) op volledig zoete wateren opgroeien en of paaien. Zowel de corridor als de habitat functie van een estuarium is van belang voor de populatie maar niet in die mate als dat van een fint. Dit zal per soort verder worden uitgewerkt. De Europese steur en de elft verschillen benutten in verschillende levensstadia het estuarium. Enerzijds als corridor (volwassen) of als juveniele of sub adult. Voor de aal en de (zee)forel is de corridor functie van belang, maar minder sterk als dat voor de zalm. De forel kan met zogenoemde 'strayers' altijd een deel van de populatie 'waarborgen', waar de zalm dit niet kan. Paling kan zowel op zoet als zout water opgroeien en dus ook in het estuarium. Echter, de populatie als geheel is niet afhankelijk van het estuarium als habitat functie.

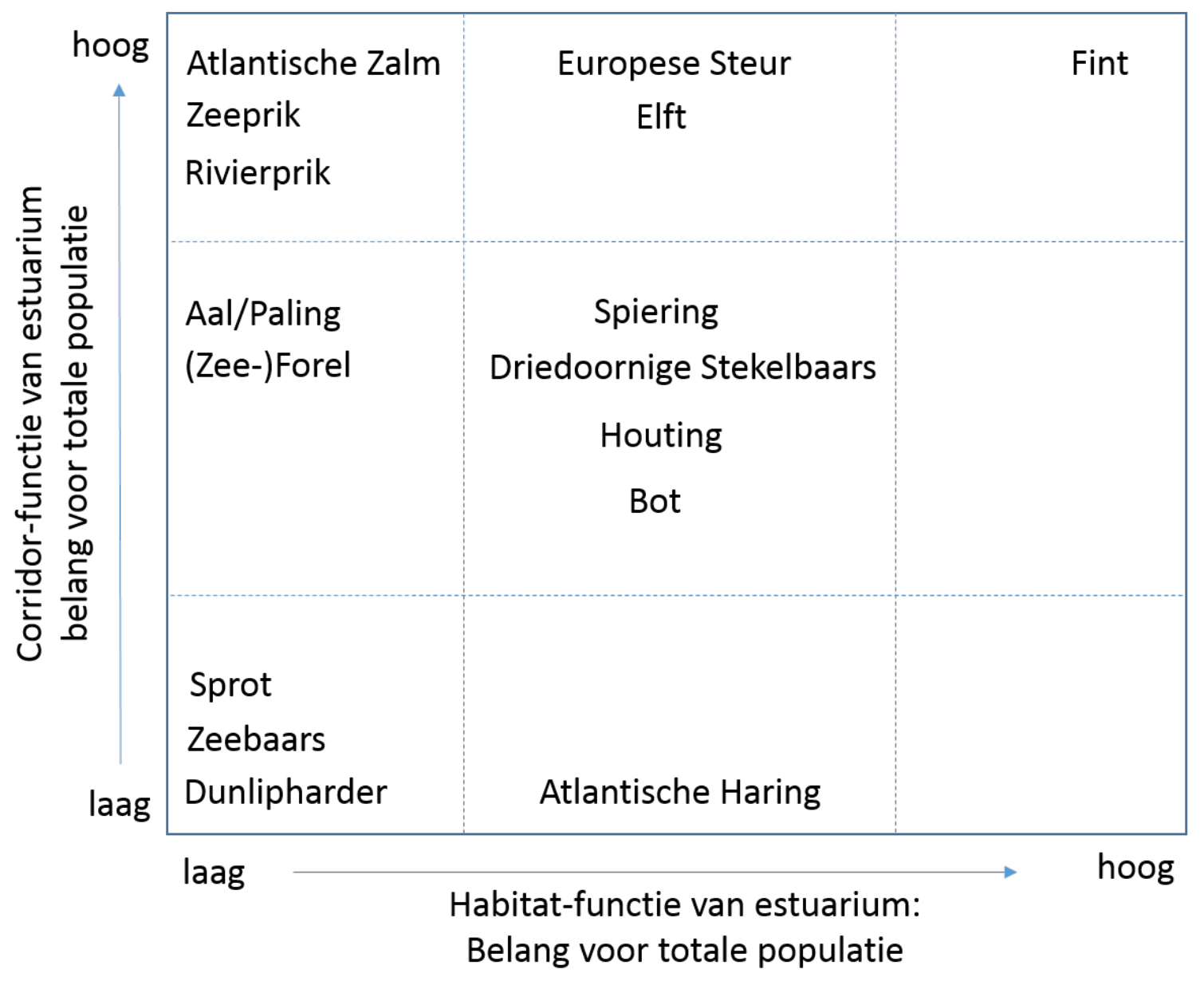

Figuur 5.2 Weergave van de mate van belang van een estuarium als corridorfunctie (Y-as) en de mate van belang van het estuarium als habitat functie. 
Aangezien door de Kier met name de corridor functie sterk zal verbeteren, is de verwachting dat de soorten weergegeven in het linker en links midden gedeelte van Figuur 5.2 het meest zullen profiteren van de Kier. Daarentegen zullen de kritische soort (fint) rechtsboven in de grafiek pas gaan profiteren zodra meer van de estuariene dynamiek is hersteld.

In de volgende paragrafen wordt een prognose per soort gegeven voor deze 16 verschillende vissoorten. Per soort wordt een korte ecologische kenschets gegeven met typerende kenmerken. Deze informatie is grotendeels geput uit een literatuur en bronnenonderzoek voor de vismigratie rivier welke is uitgevoerd door WMR (Winter et al. 2014), waarbij in het voorliggende rapport de focus gelegd wordt naar het belang van de Kier en het toekomstige Haringvliet per soort. Hierbij zijn de volgende aspecten opgenomen: (1) een ecologische kenschets, (2) het huidige belang Haringvliet als zogenoemde corridor functie of het Haringvliet als habitat / foerageer / opgroei gebied en (3) de effecten van de Kier op de populatie omvang.

\subsection{Soortspecifieke kenschets en prognose van de effecten van de Kier}

\subsubsection{Europese Aal/Paling (Anguilla anguilla)}

\section{Ecologische kenschets en huidige status}

De Europese aal is een katadrome soort die vanuit zee het zoete water opzoekt om daar op te groeien. Aal plant zich voort in de Sargassozee en de Leptocephalus larven driften met de stroming mee naar het Europese continent en Noord-Afrika. De glasaal trekt het zoete water binnen waarna zij opgroeien van 'rode aal' naar 'schieraal'. Op dat moment is de cyclus rond, de schieraal trekt naar zee om zich daar voort te planten en uiteindelijk te sterven.

De aalpopulatie kent een sterke afname gedurende de afgelopen decennia (Dekker 2004a). Zo is de huidige lokale dichtheid gemeten bij Den Oever van glasaal slechts 1-5\% van de dichtheid in Nederland uit de jaren 60-70 (Graaf et al. 2014, Griffioen et al. 2017). Verschillende factoren zijn mogelijk verantwoordelijk voor deze sterke afname zoals vervuiling, visserij, klimaatverandering, migratiebarrières en exotische parasieten (Feunteun 2002, Wirth and Bernatchez 2003, Dekker 2004b), maar het relatieve aandeel van elk van deze factoren is onbekend. Een herkenbare negatieve factor op de aalpopulatie is het aanbrengen van veel onnatuurlijke structuren in de diverse watersystemen. Dit heeft geleid tot migratie barrières voor zowel intrekkende glasaal als uittrekkende schieraal die deels ook sterfte verhogen of vertragend werken tijdens migratie, zoals dammen, stuwen, waterkrachtcentrales, gemalen en sluizen.

In het Haringvliet kwam de aal zeer abundant voor met jaarlijkse fluctuaties in nieuwe jaarklassen en uittrek (Quak 2016). In de fuikenmonitoring van WMR wordt aal sinds 2012 in relatief grote aantallen gevangen met in het jaar 2015 ruim 2.500 stuks rode aal en een kleine 10.000 stuks schieraal. Deze resultaten zijn verkregen gedurende 12 weken vissen met 7 fuiken in het najaar (Keeken et al. 2016). In vergelijking, dezelfde periode leverde ruim 20.000 stuks baars en ruim 11.000 stuks snoekbaars op. Hoe de huidige aantallen in verhouding staan tot historische gegevens is niet bekend.

Het belang van het Haringvliet als corridor, opgroeigebied en voor de populatie

Een open migratie tussen zoet en zout water voor aal is van belang. Het belang van het Haringvliet voor de aalpopulatie voornamelijk leef / opgroeigebied. Er is weliswaar ook opgroeiende aal bekend in zout (brak) water, zogenaamde 'buitenaal' zoals die bijvoorbeeld aangetroffen worden in de Waddenzee (Keeken et al. 2016) en in de Voordelta (Hop 2016). En dit geeft aan dat voor een (waarschijnlijk klein) deel van de alen de migratie naar zoet water niet noodzakelijk is. De bijdrage van het deel van de populatie dat in het zoute water opgroeit is onbekend, maar er wordt aangenomen dat dit relatief klein is en dat verreweg het grootste deel van de aalpopulatie afhankelijk is van intrek in zoete wateren.

Het Haringvliet vormt historisch gezien een opgroei gebied voor aal (Quak 2016) en het is, ook in de huidige situatie nog steeds een belangrijk gebied is voor zowel opgroei als doortrek. Het Haringvliet is voor de Europese aal populatie één van de vele locaties waar aal voorkomt en opgroeit. Het Haringvliet draagt daarom bij aan de populatie van de Europese aal. De barrière functie zal met de Kier deels 
worden opgelost, maar het Haringvliet zelf als opgroeigebied is geen bottleneck voor de aal populatie als geheel (1 grote mixende populatie).

Winter and Bierman (2010) hebben aangetoond dat schieraal die vanuit het Haringvliet naar zee trekt, dit doet via de Haringvlietsluizen wanneer het spuidebiet hoger is dan $1000 \mathrm{~m}^{3} / \mathrm{s}^{7}$ (Figuur 5.3). Bij lagere spuidebieten 'kiezen' schieralen ervoor om via het nabijgelegen kanaal Spui naar zee te trekken (via de haven van Rotterdam) zelfs ondanks het feit dat het onder die afvoeren toch mogelijk moet zijn voor schieraal om via tenminste één of enkele van de spuisluizen in de Haringvlietdam naar zee te trekken. Er zijn geen aanwijzingen voor ophoping van schieraal of uitgebreid zoekgedrag in de directe nabijheid van de Haringvlietsluizen in tijden van laag spuidebiet. De uittrek van schieraal vanuit het Haringvliet lijkt nauwelijks beperkt te worden door de spuisluizen omdat het Spui een goede alternatieve route is voor wegtrekkende schieraal tijdens lage rivierafvoeren.

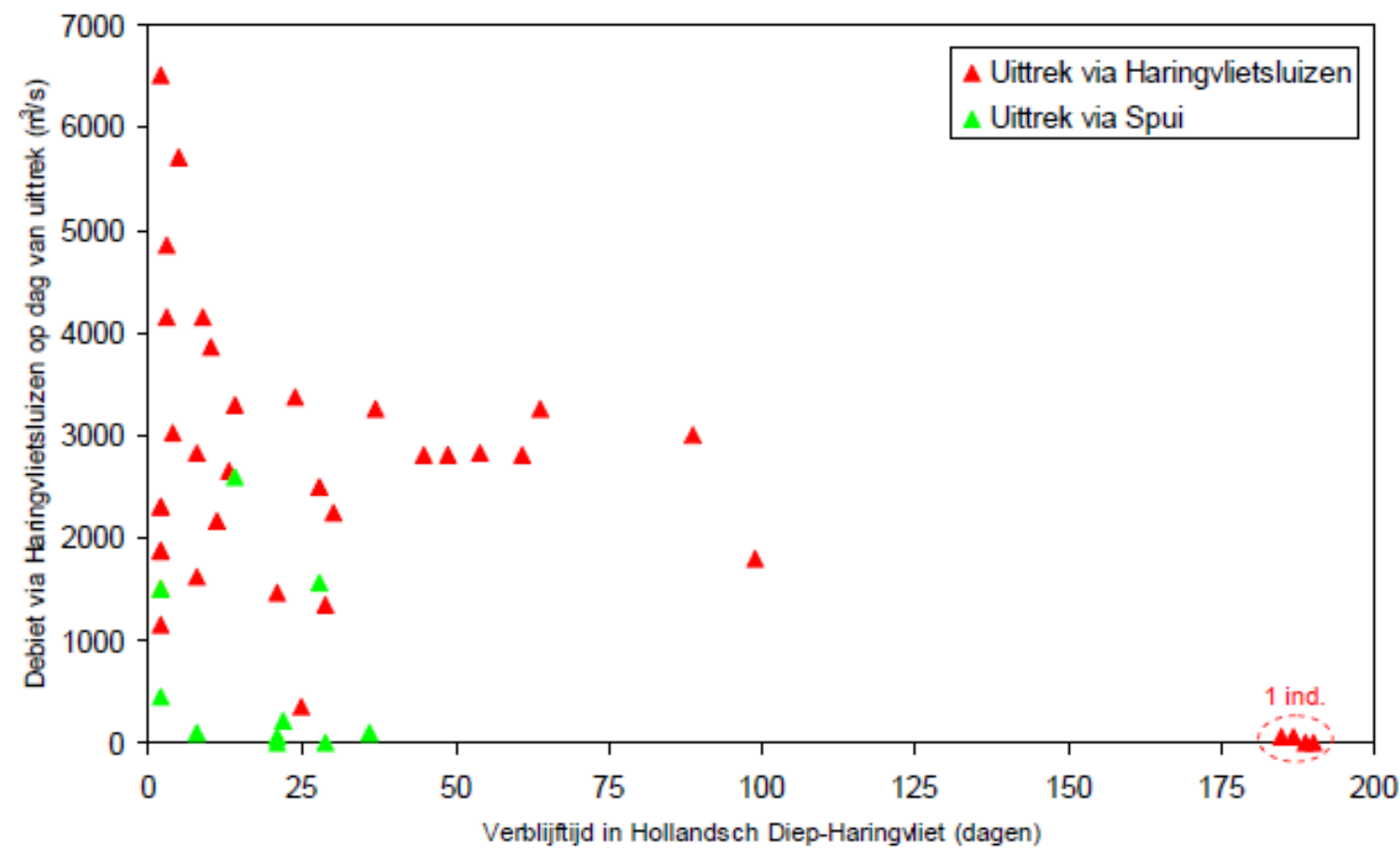

Figuur 5.3 Voor elk van de gezenderde schieralen die met zekerheid in het Haringvliet zijn aangeland is bepaald wat het spuidebiet via de Haringvlietsluizen bedroeg ten tijde van de uittrek via hetzij de Haringvlietsluizen (rood), dan wel het Spui (groen). Daarnaast is voor elk van deze schieralen bepaald hoeveel dagen er zijn verstreken tussen het tijdstip dat deze via de Bergsche Maas in het Hollandsch Diep zijn gezwommen en het tijdstip van uittrek uit het Haringvliet. De omcirkelde waarnemingen betreft schieraal die op 4 verschillende dagen bij de Haringvlietsluizen is gedetecteerd, maar uiteindelijk niet naar zee is gemigreerd (Winter and Bierman 2010).

\section{De effecten van de Kier}

Voor de uittrek van schieraal zal de Kier wellicht geen aanzienlijke verbetering opleveren omdat in het huidige systeem met lage afvoeren voornamelijk via het Spui uittrekken en bij hogere afvoeren onbelemmerd met het spuivolume naar buiten kunnen trekken via de Haringvlietdam (Winter and Bierman 2010). Het lijkt onwaarschijnlijk dat de Kier een grotere aantrekkende werking heeft op uittrekkende schieraal, maar wellicht kan het voorkomen van een zoet-zout gradiënt aan de binnenzijde van de dam zoekende schieralen op het spoor zeten van kleinere spuivolumes tijdens perioden met geringere afvoer. Voor glasaal daarentegen zal de Kier naar verwachting duidelijk betere intrekmogelijkheden bieden. De glasaal is grotendeels afhankelijk van waterstromen en het zogenoemde selectief getijde transport. Een lokstroom gecreëerd door de Kier moet dan wel (1) merkbaar zijn en (2) benut worden. Daarnaast is ook een eventueel 'wegspoel effect' van toepassing na een spui event. Indien dit het geval is zal een succesvolle intrek afhankelijk zijn van de vindbaarheid van de Kier en de tijd dat er een migratie mogelijkheid is. Bijvoorbeeld, bij de Afsluitdijk is gebleken dat glasaal ook na een lang spuivenster met hoge stroomsnelheden vrijwel direct in het midden van de spuikom aanwezig

\footnotetext{
${ }^{7}$ Afvoer via de spuisluizen van de Haringvlietdam
} 
is en het 'wegspoeleffect' beperkt van invloed bleek te zijn op glasaal (Griffioen et al. 2014). De prognose voor de effecten van de Kier op de aal in het Haringvliet is dat de intrek wordt verbeterd en het Haringvliet in grotere mate benut kan worden als leef / opgroeigebied.

\subsubsection{Bot (Platichthys flesus)}

\section{Ecologische kenschets en huidige status}

Bot is een katadrome vissoort waarvan de paaigebieden in open zee liggen (Morais et al. 2011). In de winter trekken de volwassen dieren naar diepere delen van de Noordzee. 's Zomers gebruiken volwassen botten estuaria als voedselgebied. In het voorjaar en voorzomer trekken jonge botlarven stroomopwaarts de estuariene gebieden en rivieren op middels selectief getijdetransport en zijn hierbij dus afhankelijk van de daar heersende waterstromen (Bos 1999, Jager and Mulder 1999, Jager 2001). Botten kunnen ook in gebieden worden gevonden waar het water een laag zout gehalte heeft (Bos and Thiel 2006).

\section{Het belang van het Haringvliet als corridor, opgroeigebied en voor de populatie}

Het belang van het Haringvliet voor bot is voornamelijk dat het functioneert als leef of opgroeigebied. Omdat opgroei van bot ook in zoute milieus kan plaatsvinden is het voor het voortbestaan van de soort niet strikt noodzakelijk dat ze naar zoet water kunnen trekken, maar herstel van goede migratiemogelijkheden tussen zout en zoetwater vergroot het opgroeiareaal flink en daarmee kan de totale populatieomvang toenemen (Daverat et al. 2012). De bot die in euryhaline zone van het estuarium gevonden kan worden is de enige platvis van West-Europa die tot diep in het zoet water gevonden kan worden (Vethaak 2013), zolang er maar geen barrières op de route liggen. Historisch zijn botten tot honderden kilometers landinwaarts in de Duitse Rijn waargenomen. De meeste Nederlandse botten komen voor in ondiepe kustwateren en estuaria zoals de Eems Dollard en de Westerschelde. Ook in grotere brakwatermeren en zoetwatermeren zoals het IJsselmeer worden botten aangetroffen (Keeken et al. 2016). Een deel van de botten uit het kustwater trekt de rivieren op, de rest van de botten groeit op in kustwateren en estuaria. In het zoete water verblijven de botten hooguit enkele jaren om weer naar zee te trekken om te paaien.

\section{De effecten van de Kier}

Net als glasaal zijn botlarven (sterk) afhankelijk van getijde stroming. Ook bij bot is een succesvolle passage via de Kier afhankelijk van de vindbaarheid en het fysiek in staat zijn van het passeren van de Kier. Of zij bij het spuien worden weggespoeld uit de Voordelta is een onbekende factor en of zij, net als glasaal na het spuien weer snel nabij de dam te vinden zijn, is minder bekend (Griffioen et al. 2014). Aangezien in de huidige situatie bot wordt aangetroffen in het Haringvliet zal de Kier hier naar verwachting ook een positieve bijdrage aan leveren. De bot die nu in het Haringvliet voorkomt komt wellicht via het Spui naar binnen. Aantallen en formaten zijn onbekend, maar naar verwachting zullen met de Kier veel meer botlarven in het Haringvliet terecht komen dan nu het geval is. Bij de Afsluitdijk is er begin jaren 1990 een situatie geweest waarbij er een verruimd spuiregime werd aangehouden. Op deze manier had zout water een grotere kan om binnen te treden. Er zijn in die jaren sterke aanwijzingen dat bot met instromend water in grotere aantallen het IJsselmeer op zijn gezwommen. Dit is gebleken uit een vergelijking tussen de Catch Per Unit Effort (CPUE) met surveys op het IJsselmeer en de Waddenzee. De verhouding van de CPUE van bot verschoof in de jaren na het verruimde spuiregime, waarbij er in relatieve zin meer bot werd gevangen dan voor het verruimde spuiregime (Winter et al. 2014). Dit is mogelijk het gevolg van een verbeterde intrek. Het is niet ondenkbaar dat er in het Haringvliet eenzelfde trend waarneembaar zal zijn met de komst van de Kier. Echter, het Haringvliet vormt in de huidige situatie geen cruciaal element in de populatie van bot en dat zal met de Kier ook niet wezenlijk gaan veranderen. De prognose voor de effecten van de Kier op bot in het Haringvliet is dat de intrek wordt verbeterd en het Haringvliet in grotere mate benut kan worden als leef / opgroeigebied.

\subsubsection{Driedoornige stekelbaars (Gasterosteus aculeatus)}

\section{Ecologische kenschets en huidige status}

Driedoornige stekelbaars is een zeer flexibele soort die zich zowel in zout, brak, als zoet water kan voortplanten, en daarbij zowel resident (morphotype: leiurus) als anadroom (morphotype: trachurus) kan zijn. Toch komt de driedoornige stekelbaars volgens Hop et al (2011) nauwelijks voor in het Haringvliet. Een verklaring hiervoor kan worden gezocht in de afsluiting van het Haringvliet (Emmerik and Nie de 2006). De anadrome variant in Nederland is duidelijk veel minder talrijk geworden door de 
vele barrières die zijn opgericht tussen het zoete en het zoute water. Driedoornige stekelbaars is door zijn kleine lichaamslengte een goede prooi voor visetende vogels zoals lepelaars, sterns, meeuwen, reigers, zaagbek etc. Maar ook piscivore vissen prederen op de stekelbaars, zoals snoek, baars en wellicht ook zoutwater vissen in de Voordelta zoals zeebaars.

\section{Het belang van het Haringvliet als corridor, opgroeigebied en voor de populatie}

Het belang van het Haringvliet voor de driedoornige stekelbaars (diadrome variant) is voornamelijk dat het functioneert als paaigebied of corridor. Voor de migrerende subpopulaties is migratie tussen zoet en zout van belang, voor de niet migrerende subpopulaties zijn zoet-zout overgangen niet van belang. Driedoornige stekelbaars kwam historisch gezien wisselend tot abundant voor in het Haringvliet (Hop 2011, Quak 2016). In de huidige situatie wordt de trekkende driedoornige stekelbaars in het Haringvliet nauwelijks gevangen (Hop 2016). Voor de driedoornige stekelbaars wordt in de huidige situatie de intrek waarschijnlijk belemmerend en is deze niet in staat om het aanwezige habitat areaal optimaal te kunnen benutten.

\section{De effecten van de Kier}

De driedoornige stekelbaars beschikt over een flexibiliteit in gebruik van zowel zoete, brakke als zoute habitats. Met de verbeterde intrekkansen met de Kier, met name in het voorjaar, is het de verwachting dat de populatie zal kunnen toenemen in het Haringvliet en dat zij naar verwachting relatief weinig hinder zullen ondervinden van droge perioden (doorgaans in oktober en volgende maanden) met gesloten spuideuren en zoete omstandigheden aan de binnenzijde. Wellicht dat de zeegaande migratie van jonge 0 -jarige stekelbaars in droge perioden wel belemmerd zal worden, maar daar valt niets met zekerheid over te zeggen omdat over de (timing en omvang van) zeegaande migratie van stekelbaars nog heel weinig bekend is. De diadrome populatie in het Haringvlietstroomgebied zal naar verwachting behoorlijk groter kunnen worden na instellen van de Kier.

\subsubsection{Dunlipharder (Liza ramada)}

\section{Ecologische kenschets en huidige status}

Dunlipharder is een zoutwatervissoort met een voornamelijk plantaardig dieet. Deze soort kan tot diep in estuaria en zelfs zoetwatersystemen voorkomen, maar de populatie is hier niet afhankelijk van.

\section{Het belang van het Haringvliet als corridor, opgroeigebied en voor de populatie}

Het belang van het Haringvliet voor dunlipharder is voornamelijk dat het functioneert als foerageergebied. Slechts een deel van de dunlipharder populatie kan tijdelijk tijdens het zomerhalfjaar zoetere habitats benutten voor foerageren, maar dit is niet essentieel voor het voltooien van de levenscyclus. Dat kan ook in volledig zoute habitats. De draagkracht voor de populatie zou mogelijk groter kunnen worden als de omvang van het foerageer-areaal dat beschikbaar is beperkend zou zijn voor de populatie dunlipharder. Echter, welke factoren de huidige populatie beperken is onbekend voor deze soort.

\section{De effecten van de Kier}

Dunlipharder wordt in de huidige situatie in het Haringvliet aangetroffen (Hop, 2016). De verwachting is dat deze met de Kier gemakkelijker binnen kan komen. De soort is vooral een zomergast en in het begin van de zomer en in die periode zullen met de Kier relatief veel deuren open kunnen staan. De potentie van het Haringvliet voor dunlipharder is dan ook goed als een uitbreiding van beschikbaar foerageergebied voor deze soort met zeer hoge zoetwatertolerantie. In hoeverre de populatie van dunlipharder in totaliteit toe kan nemen door de Kier is onzeker, maar naar verwachting zal een toename beperkt zijn omdat het merendeel van de populatie in buitengaatse wateren vertoeft.

\subsubsection{Elft (Alosa alosa)}

\section{Ecologische kenschets en huidige status}

De elft is een anadrome trekvis die in scholen leeft in het open water. Elft is een haringachtige die een lengte tot $70 \mathrm{~cm}$ kan bereiken. De paai vindt doorgaans plaats op grindbanken in de middenloop van rivieren bij 16 tot 18 graden Celsius, waarna de volwassen dieren die de paai hebben overleeft het zoete water weer verlaten (Lucas and Barras 2001). In de Rijn lagen de paaiplaatsen zelfs tot voorbij Basel (de Groot 2002). De larven en juveniele van elft groeien op in de rivier. Na het eerste en soms tweede jaar trekken de juveniele elften naar zee, waarbij een deel gebruik maakt van estuaria om op te groeien (Lochet et al. 2009). 
Elft is in het midden van de jaren '30 van de vorige eeuw verdwenen uit de Nederlandse zoete wateren door overbevissing, migratiebarrières, verslechtering van waterkwaliteit en rivierwerken (de Groot 2002). Quak (2016) geeft aan dat de elft vangsten na 1885 sterk zijn gedaald. Overbevissing van het paaibestand vanaf 1878 , met vangsten van meer dan 300.000 stuks rond 1885 , is hiervan de meest waarschijnlijk oorzaak geweest. Hoek (1899), heeft de achteruitgang van de elft bestudeerd en komt tot de slotsom dat het uitvoeren van riviernormalisaties in de Rijn nabij de paaigebieden de soort noodlottig geworden is. De ondiepe delen tussen de kribvakken, waar de paaiplaatsen zich bevonden, werden namelijk volgestort met baggermateriaal (Hoek 1899). Incidenteel zijn sindsdien enkele exemplaren gevangen, maar deze 'strayers' van buitenlandse populaties waren duidelijk onvoldoende om de soort te doen terugkeren.

Het is niet aan de afsluiting van het Haringvliet te wijten dat de elft is verdwenen, dat was immers al eerder gebeurd Quak (2016). Echter, de afsluiting van het Haringvliet van de Noordzee creëert wel een beperking voor de mogelijke terugkeer van de soort. Omdat de enige grotere populaties van elft zich ver van het Rijn en Maas stroomgebied bevinden (bijvoorbeeld in de Dordogne in Frankrijk) is besloten om een herintroductieprogramma voor elft op te starten in Duitsland. Gedurende 2011-2015 werden elftlarven uitgezet in het Rijnstroomgebied in het kader van dit LIFE herintroductieproject (LANUV 2011). Dit heeft geresulteerd in de terugvangst van zowel juveniele als volwassen elft in de Rijn in de daarop opvolgende jaren. Echter, of de huidige omstandigheden voor een herstel van een elft populatie inmiddels voldoende zijn verbeterd, zal in de komende jaren moeten blijken.

\section{Het belang van het Haringvliet als corridor, opgroeigebied en voor de populatie}

Het belang van het Haringvliet voor elft is voornamelijk dat het functioneert als corridor naar hoger gelegen riviergebieden. Het belang van een herstelde, open migratie tussen zoet en zout water voor elft is groot. Elft plant zich voor in de middenstroomse gedeeltes van het Rijngebied en voor de soort is het van belang dat ze op kunnen trekken tot deze paaigronden. Het Haringvliet is, naast de Afsluitdijk en de Nieuwe Waterweg één van de drie routes om het bovenstroomse deel van de Rijn te bereiken. Op dit moment is alleen de Nieuwe Waterweg vrij optrekbaar.

\section{De effecten van de Kier}

Elft trekt in het voorjaar de rivier op en dan zijn de intrekmogelijkheden via de Kier relatief gunstig. De Kier impliceert dan ook een sterke verbetering voor de intrek van volwassen elften. Hiermee is slechts aan één voorwaarde voldaan voor de terugkeer van de elft. In hoeverre de Kier ook gaat leiden tot een toename in de populatieomvang hangt verder af van in hoeverre andere factoren het herstel van de elft-populatie blijven beïnvloeden (zoals visserij en habitatkwaltiet) en is op voorhand moeilijk in te schatten.

\subsubsection{Fint (Alosa fallax)}

\section{Ecologische kenschets en huidige status}

Fint is een anadrome soort, dus een soort die vanuit zee het zoete water opzoekt om te paaien. Als paaihabitat prefereren finten grindbanken in het zoetwatergetijdengebied van estuaria (Maitland and Lyle 2005). De eieren worden pelagisch afgezet, zijn niet-kleverig en bewegen zich vrijelijk in de lagere gedeelten van de waterkolom met het getij mee (Esteves and Andrade 2008). Na het paaien trekken de adulten terug naar zee. De eieren bevinden zich in het zoete water. Als de larven uit het ei komen, drijven ze stroomafwaarts, waar ze een jaar pelagisch verblijven (Groot de 1992) en verder uitstromen naar meer open zee.

\section{Het belang van het Haringvliet als corridor, opgroeigebied en voor de populatie}

Het belang van het Haringvliet voor fint is voornamelijk dat het (zou moeten) functioneren als corridor naar gebieden met een zoetwatergetijde slag. Dit is zowel in de huidige als de toekomstige situatie niet aanwezig. Het belang van een open migratieverbinding tussen zoet en zout water voor fint is groot. In het verleden paaide de fint in de Merwede en de Bergse Maas, maar de werkelijke paaigebieden zijn nooit achterhaalt (Groot de 1992). In de Eems werden in augustus 1999 in het midden van de rivier jonge finten van circa $10 \mathrm{~cm}$ aangetroffen (Kleef and Jager 2002). In het voorjaar van 2005 werden paaiende finten waargenomen in de Beneden-Merwede (waarnemingen vissers van Fa. Klop). Of daadwerkelijk in Nederland gepaaid wordt is nog steeds de vraag, en als dat zo is, is het de vraag hoe succesvol de overleving van deze paai dan zal zijn. In het Haringvliet en aangrenzend benedenrivierengebied ontbreekt de benodigde getijdynamiek en geschikt habitat (getijdegebied met 
zand of grind). Voor de soort is het van belang dat deze de rivier op kunnen trekken tot de paaigronden. In ons land was de Brabantse Biesbosch in het verleden een belangrijk paaigebied voor de fint. Zeer waarschijnlijk vervulden ook de Oude Maas, Lek, Eems en Schelde ook een dergelijke functie.

\section{De effecten van de Kier}

Fint is een soort die hoge habitateisen stelt voor paai- en opgroei en heeft hiervoor een goed functionerend estuarium nodig. De eieren worden afgezet in het zoetwatergetijdengebied en bewegen zich dan met de getijdestroming mee op en neer in het getijden gebied. Aangezien er nog nauwelijks een getijdeslag in het zoetwatergebied is ( $\mathrm{ca} 30 \mathrm{~cm}$ in de Biesbosch' en er met de Kier in de getijdenstromingen en dynamiek niet veel gaat veranderen (Noordhuis 2017), zullen als er al gepaaid wordt (wat nu sporadisch het geval lijkt te zijn) in het benedenrivierengebied de eieren dan wel larven met de zoetwaterstromingen mee uitspoelen. Voor fint is de verwachting dat een verdergaand herstel naar estuariene omstandigheden nodig is om de paai- en opgroeifunctie voor deze soort voldoende te herstellen. Wel zal de intrekbaarheid voor volwassen finten sterk verbeteren, maar pas als ook het estuariene karakter aan de binnenzijde van het Haringvliet en achterliggende benedenrivierengebied wordt hersteld zal dit leiden tot een terugkeer van een grote paaienede fint-populatie zoals die er in het verleden was.

\subsubsection{Atlantische haring (Clupea harengus)}

\section{Ecologische kenschets en huidige status}

Haring is een pelagische zoutwatervissoort die in grote getale voorkomt in de Noordzee en paait op grindbanken in open zee en mondingen van estuaria. In de jaren zeventig van de vorige eeuw is de populatie door overbevissing zeer sterk gedaald maar met een beter visserijbeheer is deze daarna weer hersteld.

\section{Het belang van het Haringvliet als corridor, opgroeigebied en voor de populatie}

Het belang van een estuarium is voor de totale populatie haring op de Noordzee naar verhouding gering. Aan de andere kant, uit oogpunt van de van stapelvoedsel afhankelijke vis en vogelsoorten is een groei van het bestand aan haring(larven) in het Haringvliet, van aanzienlijk belang te noemen.

\section{De effecten van de Kier}

Aan de buitenzijde van het Haringvliet (en andere zoet-zout overgangen langs de Nederlandse kust) is jonge haring in het voorjaar/voorzomer veelvuldig aanwezig. Gezien de geringe zwemcapaciteiten van deze jonge haring zullen de intrekkansen flink toenemen voor deze soort met het instellen van de Kier. Het habitat aan de binnenzijde met een brakwatergradiënt is tijdens perioden met een werkende Kier ook geschikter als foerageer habitat dan onder de volledig zoete condities in de huidige situatie. Er zal in deze perioden naar verwachting een sterke toename van voorkomen jonge haring aan de binnenzijde van de dam gaan optreden. Lokaal zou dit gunstig kunnen zijn voor foeragerende visetende vogels en roofvissen. Aangezien de populatie haring op de Noordzee enorm groot is en er naar verhouding slechts een zeer klein deel het Haringvliet zal benutten, is het niet te verwachten dat er een effect op de haring populatie is. Of de jonge haring op het Haringvliet in de problemen gaat komen in perioden wanneer er door weinig afvoer geen sluisdeuren op een Kier staan, zal afhangen van hun reactie op het zoetspoelen dat hieraan vooraf gaat. Aangezien haring een voorkeur heeft voor licht brakwater boven volledig zoetwater, zou het goed kunnen dat de haring zich tijdens het zoetspoelen met de zoet-zout gradiënt mee naar buitengaats beweegt. Als dit niet gebeurt zouden de eenmaal ingesloten haringen in zoet water ongetwijfeld in de problemen (met sterfte als gevolg) komen gedurende perioden met gesloten spuisluisdeuren.

\subsubsection{Houting (Coregonus oxyrinchus)}

\section{Ecologische kenschets en huidige status}

In het verleden is de houting uitgestorven door het afsluiten van de Zuiderzee, vervuiling, visserij en het verdwijnen van paaiplekken (Poulsen et al. 2012). De soort was in Nederland al verdwenen voordat de deltawerken in de zuidwestelijk Nederland van start gingen. Welke habitats in de benedenlopen, estuaria en kustgebieden belangrijk zijn (geweest) voor de opgroei van jonge houting tot volwassen stadia is niet goed bekend. Van Bemmelen (1866) noemt dat de houting in het najaar en het begin van de winter zeer algemeen voorkwam in de Zeeuwse stromen, de meeste Nederlandse rivieren en de Zuiderzee (Bemmelen 1866). In de overige jaargetijden werd de houting in 'meer of minder' grote aantallen langs de Nederlandse kusten aangetroffen. 
Over de omvang van de vangstaanvoer van houting is weinig bekend (Quak 2016). Uit het verslag van Hoek en Bottemanne (1888) blijkt dat de houting in 'talrijke' aantallen werd gevangen bij Strijenas (Hoek and Bottemanne 1888). Hiermee was het een belangrijke soort voor de handzegenvisserij (Quak 2016). De houting is een endemische soort van Waddenzee en de Nederlandse delta en trekt de rivieren op om te paaien (Poulsen et al. 2012). De eieren van de houting worden vrij in het water (pelagisch) losgelaten en ze plakken vast aan grind en vegetatie (Poulsen et al. 2012).

\section{Het belang van het Haringvliet als corridor, opgroeigebied en voor de populatie}

Het belang van het Haringvliet voor houting is voornamelijk dat het functioneert als corridor naar hoger gelegen riviergebieden voor de paai. Wanneer houting niet de bovenstroomse delen (al is de houting nooit heel diep in het Maas en Rijnstroomgebied opgetrokken) de rivier kunnen bereiken door bijvoorbeeld migratiebarrières, zijn zij genoodzaakt om beneden in de rivier te paaien. De larven komen in februari tot maart uit het ei en zijn dan $10 \mathrm{~mm}$ groot (Borcherding et al. 2006). De jonge houtingen kunnen langere of kortere tijd in zoet water verblijven, waarna ze naar zee trekken (Borcherding et al. 2008). Studies aan schubben van houtingen in het IJ ssselmeergebied laten zien dat een deel van houtingen hun volledige levenscyclus in zoetwater kunnen voltooien (Borchering et al. 2008). Gezenderde houtingen in het benedenrivierengebied verbleven voornamelijk in het Nederlandse deel van het Rijnstroomgebied, slechts een enkeling trok stroomopwaarts net over de grens met Duitsland, en een enkele houting trok via het Haringvliet naar zee (Winter et al. 2008).

\section{De effecten van de Kier}

De intrekmogelijkheden voor houting zullen verbeteren met de Kier. Aangezien houting de volledige levenscyclus ook in zoetwater kan voltooien (Borcherding et al. 2008) zal met de Kier een uitbreiding van het beschikbare habitat plaatsvinden met name rondom de Haringvlietdam, een toename in aantal lijkt aannemelijk, maar het effect op populatieniveau is meer afhankelijk van de diverse andere beperkende factoren.

\subsubsection{Rivierprik (Lampetra fluviatlis)}

\section{Ecologische kenschets en huidige status}

Rivierprik is taxonomisch gezien geen vissoort maar behoort tot de orde der rondbekken (Agnatha). Rivierprik wordt vaak meegenomen in beschouwingen over vis, mede vanwege hun anadrome levenscyclus en visachtige voorkomen. Volwassen rivierprikken trekken na enkele jaren op zee de rivieren op, naar hoger stroomopwaarts gelegen paaigebieden. In tegenstelling tot veel anadrome soorten vertonen prikken geen "homing" naar de geboorterivier (Bergstedt and Seelye 1995). De prikken sterven na de paai. De jonge prikken (zogenoemde ammocoeten) verblijven enige jaren als 'filterfeeder' in de waterbodem van rivieren en trekken bij een lengte van ongeveer 12-14 cm naar zee om als parasiet op vissen te leven, waarbij rivierprikken ook op kleinere vis als haring en sprot parasiteert, totdat ze volgroeid zijn (ongeveer 30-40 cm). Over de leefwijze en verspreiding tijdens de zeefase is zeer weinig bekend. Historisch gezien is de rivierprik in de 20ste eeuw een 'bijzaak', waarbij de prikken als aas voor kabeljauw visserij werd gebruikt (Quak 2016).

\section{Het belang van het Haringvliet als corridor, opgroeigebied en voor de populatie}

Het belang van het Haringvliet voor rivierprik is dat het functioneert als corridor naar hoger gelegen riviergebieden voor de paai. Het belang van de migratie tussen zoet en zout water voor rivierprik is groot. Voor de soort is het van belang dat deze de rivier op kan trekken tot de paaigronden. Rivierprikken worden slechts incidenteel op de Noordzee aangetroffen in monitoringen (WMR database DYFS Waddenzee). In de Noordzee-kustzone, de Waddenzee en op de overgang van zout naar zoet water, zoals het Schelde-estuarium, zijn de waargenomen aantallen groter. Dit verschil wordt zeer waarschijnlijk beïnvloed door het trekgedrag in relatie tot de voortplanting en de grotere bemonsteringinspanning in de kustzone.

Sinds 2012 is een schieraalmonitoring opgezet door WMR waarbij op zeven locaties in Nederland de uittrek van schieraal in september-november gevolgd word met fuikvangsten. Op twee van deze locaties, Kornwerderzand en het Haringvliet, wordt afwisselend ook in december gevist voor rivierprikintrek monitoring (Griffioen and Kuijs 2013). Het aanbod van rivierprik langs de kust lijkt relatief groot. De rivierprik wordt momenteel in alle grote stromende wateren van Nederland waargenomen en dus ook in het Haringvliet (Keeken et al. 2016). 


\section{De effecten van de Kier}

De huidige intrekmogelijkheden van rivierprik zijn beperkt vanwege de geringe zwemcapaciteit en naar verwachting zullen die wel sterk toenemen met het instellen van de Kier. Aangezien de intrekperiode van november tot maart loopt zal met de toegenomen migratiemogelijkheden naar verwachting een veel groter deel van het aanbod aan rivierprik naar binnen trekken. Verder is voldoende potentiële paaien opgroeiplaatsen aanwezig in het achterland om ook daadwerkelijk een toename in de totale populatie te kunnen verwachten.

\subsubsection{Spiering (Osmerus eperlanus)}

\section{Ecologische kenschets en huidige status}

Spiering kan verschillende 'life-history' strategieën vertonen. De trekkende variant (anadroom) die tot $25 \mathrm{~cm}$ groot wordt, was bijvoorbeeld in de Zuiderzee voor de afdamming met de Afsluitdijk zeer talrijk (de Groot 1992, de Groot 2002). In het Haringvliet schommelden de vangsten van 80-300 ton per jaar en na de tweede wereldoorlog daalden de vangsten tot 50-100 ton per jaar (Quak 2016). Met de afsluiting van het Haringvliet in 1970 werd de spieringvisserij beëindigd (Quak 2016). In tegenstelling tot het IJsselmeer, waar zich kort na de afsluiting van de Zuiderzee een grote 'land-locked' zoetwaterpopulatie ontwikkelde die al na 1 jaar geslachtsrijp wordt en waarbij slechts een kleiner deel 2 jaar oud wordt, is er in het Haringvliet geen dergelijke omvangrijke zoetwaterpopulatie ontstaan. Wellicht dat dit te maken heeft met de veel geringere verblijftijd van het water in het Haringvliet ten opzichte van het IJsselmeer.

\section{Het belang van het Haringvliet als corridor, opgroeigebied en voor de populatie}

Het belang van het Haringvliet voor spiering was in het verleden dat het voornamelijk functioneerde als corridor naar paai gebieden bovenstrooms het Haringvliet estuarium. Voor de trekkende variant is de migratie tussen zoet en zout water van groot belang, en voor de zoetwaterstandvis heeft dit geen belang. Zo is bijvoorbeeld tot op heden is nog geen bewijs gevonden dat de anadrome variant een bijdrage levert aan de spieringpopulatie op het IJsselmeer (Tulp et al. 2013).

\section{De effecten van de Kier}

De spiering zal veel betere intrekmogelijkheden krijgen met de Kier. Aangezien de soort ook goed kan omgaan met perioden van volledig zoetwater (voornamelijk in het najaar te verwachten) zal het spieringbestand naar verwachting toenemen met de Kier. Wellicht ook dat de concurrentiepositie ten opzichte van andere zoetwatervis door de Kier in het Haringvliet gunstiger wordt.

\subsubsection{Sprot (Sprattus sprattus)}

\section{Ecologische kenschets en huidige status}

Sprot is een kleine haringachtige (maximaal $15 \mathrm{~cm}$ ) die in zoutwater zijn levenscyclus voltooit. De populatie in de kustzones van de Noordzee zijn zeer omvangrijk en sprot komt vaak in gemengde scholen met jonge haring voor. Sprot trekt ook de estuaria in en kan lage zoutgehalten verdragen, maar paait in ondiepe zoute kustwateren. De aantallen kunnen van jaar tot jaar sterk variëren.

\section{Het belang van het Haringvliet als corridor, opgroeigebied en voor de populatie}

Het belang van een estuarium is voor de totale populatie sprot op de Noordzee naar verhouding zeer gering. De Noordzeepopulatie is groot en het aandeel dat van estuaria gebruik maakt vormt slechts een klein aandeel. Dat neemt niet weg dat lokaal hoge abundanties van sprot kunnen voorkomen in Haringvliet. In het Haringvliet de aanwezige roofvis en populaties visetende vogels kunnen sterk profiteren van een verbeterde beschikbaarheid van stapelvoedsel zoals haring, sprot en spiering hiervan.

\section{De effecten van de Kier}

Voor sprot geldt een vergelijkbare verwachting als voor Atlantische haring (zie 5.2.8), waarbij de haring wellicht sterker aangetrokken wordt tot brak/zoetwater gradiënten dan sprot. Naar verwachting zal het aantal sprots in het Haringvliet toenemen, maar wellicht niet in die mate als voor haring wordt verwacht. Omdat het onderscheid tussen zeer jonge haring en sprot niet eenvoudig is, en er weinig gerichte studies hiernaar zijn uitgevoerd, zal het lastig zijn om vast te gaan stellen in hoeverre sprot ten opzichte van haring kan profiteren van het nieuwe Kier-regime. 


\subsubsection{Europese steur (Acipenser sturio)}

\section{Ecologische kenschets en huidige status}

De Europese steur is een anadrome vissoort die voorkwam in de Rijn en in alle grote rivieren van West Europa die in verbinding staan met de Oost Atlantische Oceaan, de Middellandse zee en de Zwarte zee. In Europa is nog maar één restpopulatie over: de Gironde-populatie (Houben et al. 2012). De steur plant zich waarschijnlijk alleen nog voor in het Gironde-Garonne-Dordogne stroomgebied in Frankrijk en zelfs hier vindt er tegenwoordig slechts sporadisch nog natuurlijke paai plaats. De soort is dan ook ernstig bedreigd in zijn voortbestaan. Volwassen steuren leven op zee en trekken in de zomer grote rivieren op om zich voort te planten. De mannetjes zijn geslachtsrijp na circa 12 jaar, de vrouwtjes na circa 15 jaar (Williot et al. 1997, Williot 2011). Subadulten (2-10 jaar) trekken jaarlijks naar en van het estuarium tussen april en september (Williot et al. 1997, Houben et al. 2012). De jonge Europese steuren leven de eerste twee jaren in de rivier ( $0-2$ jaar) en migreren als subadult ( 2 - 10 jaar) jaarlijks tussen het estuarium en open zee.

De steur is sinds het midden van de jaren ' 50 van de vorige eeuw in Nederland uitgestorven (De Groot 2002). Van Bemmelen (1866) geeft aan dat de steur in historische tijden relatief veel in de Zuiderzee voorkwam. Tegenwoordige vangsten van steur in Nederland betreffen vrijwel zonder uitzondering exotische steursoorten die vanuit de vijverhandel afkomstig zijn.

In het kader van voorwerk op een eventuele herintroductie in het Rijn stroomgebied van de Europese steur zijn er in 2012 en 2015 experimentele uitzettingen gehouden van in totaal 100 steuren van 3-5 jaar oud. Deze zijn afkomstig uit Franse kweek en werden in Nederland in de Rijn uitgezet op de Waal nabij de grens met Duitsland. Dit project was onderdeel van twee telemetrie studies, gehouden met het Nedap Trail systeem van Rijkswaterstaat en georganiseerd door Stichting ARK, het Wereldnatuurfonds en Sportvisserij Nederland (Brevé et al. 2013). Een groot deel van deze dieren werd gemiddeld een twee weken na uitzet gedetecteerd in het havengebied van Rotterdam, waar volgens de auteurs de vissen zich wellicht aanpasten aan het hogere saliniteitsgehalte. In totaal is van $30 \%$ van deze steuren bekend dat deze de Noordzee ingezwommen zijn. In 2012 werden zes steuren binnen 1 maand terug gevangen door garnalenkotters, vrij regelmatig verspreid langs de Nederlandse kust. De steuren werden levend vrijgelaten na vangst, echter, dit indiceert wel een grote visserijdruk.

\section{Het belang van het Haringvliet als corridor, opgroeigebied en voor de populatie}

Het belang van het Haringvliet voor de steur is in de huidige situatie niet aanwezig omdat de steur is uitgestorven. In het verleden was het Haringvliet een belangrijke corridor naar hoger gelegen paaigebieden en functioneerde het als leefgebied voor juveniele en subadulten \{Winter, 2015 \#1353\}. De Europese steur kan in principe de paaigronden bovenstrooms in de Rijn bereiken via de vrij optrekbare Nieuwe Waterweg. Momenteel vormen de spuisluizen in de Haringvlietdam een belemmering voor de migratie, maar met de Kier zal dit ongetwijfeld verbeteren. De Europese steur paait in de hoofdstroom en tot ver in Duitsland zijn er geen andere migratiebarrières voor deze soort aanwezig. Voor jonge steuren die vanaf de paaigronden stroomafwaarts migreren en vervolgens tot twee jaar in het estuarium leven en jaarlijks tussen open zee en het estuarium trekken is een grote zoet-zout gradiënt essentieel. Deze estuariene gebieden zijn met de Haringvlietdam verdwenen in het Haringvliet (Winter et al. 2015). Met de opwarming van het klimaat wordt het Rijn stroomgebied ten opzichte van het Gironde/Garonne/Dordogne stroomgebied geschikter voor paai en opgroei en daarmee vormt de Rijn (en het Haringvliet) in de toekomst een potentieel belangrijk stroomgebied voor de Europese steur.

\section{De effecten van de Kier}

De intrekmogelijkheden voor steur zullen groter worden. In hoeverre het habitat aan de binnenzijde ook gunstiger wordt voor opgroei van jonge steur is nog onzeker. Wellicht is hiervoor meer herstel van het estuariene karakter van het benedenrivierengebied nodig, zoals getijde en een meer permanente, natuurlijkere zoet-zout overgang (zonder zoetspoelen in droge perioden). Daarnaast zullen vele andere factoren bepalend zijn voor potentieel herstel van de steur met de Kier, zoals visserijsterfte, scheepvaart (er zijn aanwijzingen dat er aanvaringsslachtoffers vallen met scheepschroeven), hybridisatie ten gevolge van de illegale introductie van exotische steursoorten en een beperkende habitatkwaliteit (Winter et al. 2015). 


\subsubsection{Atlantische zalm (Salmo salar)}

\section{Ecologische kenschets en huidige status}

De levenscyclus van de anadrome zalm begint in de bovenlopen van rivieren, waar de eieren in snelstromende grindrivieren en - beken worden afgezet. Na een opgroeifase van één tot drie jaar trekken jonge zalmen (lengte dan gemiddeld 15-20 cm, zogenaamde 'smolts') naar zee. Ze leven één tot enkele jaren op de Atlantische Oceaan waarna de inmiddels volwassen zalmen in de zomer en het najaar naar hun geboorterivier terugkeren om in de winter te kunnen paaien.

De grote zalmpopulatie die voorheen in het Rijnstroomgebied paaide is in de eerste helft van de twintigste eeuw compleet uitgestorven. Dit werd veroorzaakt door een combinatie van overbevissing, slechte waterkwaliteit, verlies van paai- en opgroeihabitat door bijvoorbeeld grindwinning maar ook door een verhoogd slibgehalte en de aanleg van migratiebarrières op de trekroutes (de Groot 2002, Schneider 2009).

In de jaren negentig is een herintroductieprogramma gestart in de bovenlopen van het Rijn stroomgebied, waarbij grote aantallen jonge zalm werden uitgezet in diverse Duitse en Franse zijrivieren. Na een duidelijke toename in de aantallen volwassen zalmen die de Rijn optrekken zijn de aantallen enigszins gestabiliseerd (Wiegerinck et al. 2009). Er is momenteel nog geen sprake van een zichzelf in stand houdende populatie (Schneider 2009). De huidige bovenstroomse Rijn-populatie kent nog een te gering terugkeerpercentage van de wegtrekkende smolts waardoor de instandhouding van de populatie momenteel nog afhankelijk is van uitzet van jonge zalm in de bovenstroomse delen van de Rijn.

\section{Het belang van het Haringvliet als corridor, opgroeigebied en voor de populatie}

Het belang van het Haringvliet voor de zalm is dat het functioneert als een corridor naar hoger geleden paaigebieden. Het belang van de migratie tussen zoet en zout water voor zalm is groot. Zalm plant zich voor in de bovenstroomse gedeelten van het Rijngebied en het is van groot belang dat zalmen de zee de rivier op kunnen trekken tot de paaigronden. Om de bovenstroomse Rijn te bereiken kunnen drie intrekroutes worden genomen: via de Afsluitdijk en de IJssel, via het Haringvliet of via de Nieuwe waterweg. De laatstgenoemde is momenteel de enige vrij optrekbare route naar het bovenstroomse deel van de Rijn.

\section{De effecten van de Kier}

De zalm zal betere intrekmogelijkheden krijgen in het Haringvliet. Nu komt er al een deel binnen en is de Nieuwe Waterweg ook een al optrekbare optie. Herstel van optrekbaarheid is belangrijk, toch bestaan er nog vele andere beperkende factoren die van grote invloed zijn op herstel van de zalmpopulatie in de Rijn en Maas. Deze zullen ook moeten worden weggenomen wil het effect van de Kier zichtbaar worden in de gewenste populatie toename.

\subsubsection{Zeebaars (Dicentrarchus labrax)}

\section{Ecologische kenschets en huidige status}

De zeebaars is een zoutwatersoort die met name in het zomerhalfjaar langs de Nederlandse kust verschijnt, voornamelijk om te foerageren, maar er zijn ook aanwijzingen van paai en zelfs overwintering. De zeebaars kan lagere zoutgehalten tolereren, zoals in het Noordzeekanaal in de haven van Amsterdam, maar trekt doorgaans niet heel diep de estuaria in.

\section{Het belang van het Haringvliet als corridor, opgroeigebied en voor de populatie}

Het belang van het Haringvliet voor zeebaars is voornamelijk dat het functioneert als foerageergebied. Slechts een deel van de zeebaarspopulatie zal tijdelijk tijdens het zomerhalfjaar zoetere habitats benutten voor foerageren en dit is niet van essentieel belang voor het voltooien van de levenscyclus. Dat lukt ook in volledig zoute habitats. Het belang van het Haringvliet voor zeebaars zal gering zijn op populatieniveau, desalniettemin zullen zeebaarzen ongetwijfeld willen jagen op de meer aanwezige haring, sprot en zeebaars in de zoet-zout overgangszone in het Haringvliet en om en nabij de sluizen i.e. pijlers van de Haringvlietdam waar hogere stroomsnelheden de kleinere vis tot een eenvoudiger prooi kan maken. Een vergelijkbare situatie is bijvoorbeeld bekend van de Oosterschelde stormvloedkering (pers. comm. N. Breve).

\section{De effecten van de Kier}

Voor zeebaars geldt een vergelijkbare situatie als voor dunlipharder (zie 5.2.5). Deze soort is met name een zoutwatersoort die ook periodiek en facultatief zoet water kan benutten om te foerageren. De 
intrekmogelijkheden voor zeebaars zullen met de Kier zeker groter worden en daarmee vergroot ook de kans dat meer zeebaars in het Haringvliet komt foerageren. Voor de Noordzee populatie zeebaars zal dit weinig tot geen betekenis hebben, toch zal het lokale voorkomen van zeebaars in het brakkere eerste deel van het Haringvliet naar verwachting toenemen.

\subsubsection{Zeeforel (Salmo trutta)}

\section{Ecologische kenschets en huidige status}

Forel kent verschillende 'life-history' strategieën binnen dezelfde populatie, waarvan de één permanent op de rivieren verblijft (residente strategie, verschijningsvorm/morpha 'beekforel') en de ander naar zee trekt (migrerende strategie, verschijningsvorm/morpha 'zeeforel'). Elk individu kan zich afhankelijk van de opgroeiomstandigheden ontwikkelen tot één van beide verschijningsvormen. $\mathrm{Er}$ is dus geen sprake van twee verschillende ondersoorten of subpopulaties per rivier zoals nog vaak wordt aangegeven. In de monitoringprogramma's worden af en toe forellen gevangen die veel uiterlijke kenmerken van de beekforel hebben. Omdat de vissen bij de Haringvlietdam migrerende individuen zijn van de verschijningsvorm zeeforel, is deze soort in deze rapportage verder als zeeforel aangeduid. Jonge zeeforel trekt, evenals zalm, na één tot drie jaar in de rivieren te hebben geleefd in het voorjaar naar zee, om vervolgens na enkele jaren als volwassen vis weer terug te keren naar de rivieren (J onsson and Jonsson 2002). In tegenstelling tot zalm verblijft zeeforel in zeeën en kustwateren in de buurt van hun geboorterivier en kan ook tussentijds wel in enige mate het zoete water intrekken. De paaigebieden van zeeforel en zalm overlappen deels, waarbij zalm paait op ondiepere en sneller stromende gedeeltes. De pre-smolts van zeeforel verlaten na 1 tot 6 jaar het zoete water in het voorjaar en groeien op in het estuarium of de zee. Na 1 tot 3 jaar op zee te zijn geweest trekken de zeeforellen de rivier weer op in de vroege winter. Na de paai sterft een deel van de ouderdieren, terwijl een deel weer teruggaat naar zee om op een later moment nogmaals aan de paai mee te doen.

\section{Het belang van het Haringvliet als corridor, opgroeigebied en voor de populatie}

Het belang van het Haringvliet voor zeeforel is enerzijds dat het functioneert als foerageergebied, en anderzijds als corridor naar hoger gelegen paaigebieden. Het belang van de migratie tussen zoet en zout water voor zeeforel is groot. Zeeforel plant zich voort in de bovenstroomse gedeeltes van het Rijngebied, in de bovenstroomse delen van de Vecht (Winter 2007) en vermoedelijk (beperkt) in de Geul in de Maas en meer bovenstrooms in de Ardennen. Voor de soort is het van belang dat deze de rivier op kunnen trekken tot de paaigronden. Doordat sommige individuen op de rivier blijven als beekforel en dat deze eigenschap zich kan ontwikkelen bij het opgroeien, doet de soort aan een vorm van risicospreiding die de populatie in stand kan houden (Lucas and Barras 2001, Gosset et al. 2006). In hoeverre de Haringvlietdam een barrièrebarrière vormt voor zeeforellen was onderwerp van onderzoek in 2003 en 1998 door Rijkswaterstaat (Breukelaar et al. 1998, Bij de Vaate et al. 2003). Hierbij is de migratie van zeeforel vanuit zee richting de zoete wateren bestudeerd met behulp vanen NEDAP-telemetrie. Het feit dat gezenderde zeeforellen terug zijn gevonden in andere delen van Europa, zoals Frankrijk en Noorwegen (Bij de Vaate et al. 2003) kan erop wijzen dat niet alle zeeforellen die bij de Nederlandse kust worden gezien ook daadwerkelijk in Nederland willen binnentrekken.

\section{De effecten van de Kier}

De zeeforel zal betere intrekmogelijkheden krijgen in het Haringvliet. Nu komt er al een deel binnen en is de Nieuwe Waterweg ook een optie. Er zijn vele andere beperkende factoren voor de zeeforel populatie. Daarnaast bevolkt een deel van de zeeforel populatie als standvis permanent de bovenlopen van het Rijn- en Maas stroomgebied. Anders dan voor de zalm gebruikt de zeeforel de Nederlandse kustwateren en estuaria ook als foerageergebied. De Kier zal zowel de intrekmogelijkheden vergroten alsook het foerageer-areaal van kust afschuimende zeeforellen vergroten. Hierdoor zou de draagkracht van de populatie voor (zee)forel door de Kier groter kunnen worden.

\subsubsection{Zeeprik (Petromyzon marinus)}

\section{Ecologische kenschets en huidige status}

Zeeprik behoort evenals de rivierprik tot de orde der rondbekken. De zeeprik leeft het grootste deel van zijn leven (6-8 jaar) als ammocoete in zoet water voordat deze uiteindelijk in het najaar naar zee trekt. Daar vindt een snelle groei plaats en leeft de zeeprik als parasiet op vis. Na enkele jaren keert de zeeprik in het voorjaar terug naar de rivieren om hoog stroomopwaarts te paaien en vervolgens te sterven. Van zeeprik is grotendeels onbekend in hoeverre een paaipopulatie voorkomt in het stroomgebied van de Nederlandse rivieren. De in het Haringvliet gemelde zeeprikken (Keeken et al. 2016) kunnen afkomstig zijn uit ons omringende landen, omdat ze niet noodzakelijkerwijs terugkeren naar hun geboorterivier 
(Bergstedt and Seelye 1995). Ze selecteren rivieren op de aanwezigheid van feromonen die door de ammocoeten worden uitgescheiden (Bjerselius et al. 2000, Vrieze and Sorensen 2001).

\section{Het belang van het Haringvliet als corridor, opgroeigebied en voor de populatie}

Het belang van het Haringvliet voor zeeprik is dat het functioneert als corridor naar hoger gelegen riviergebieden voor de paai. Het belang van de migratie tussen zoet en zout water voor zeeprik is groot. Voor de soort is het van belang dat deze de rivier op kunnen trekken tot de paaigronden. Omdat zeeprikken geen homing vertonen, maar afgaan op feromonen van de larven is de Haringvlietdam één van de doorgangen richting eventuele geschikte paaigronden in het achterland en zal er ook vermenging tussen verschillende rivierpopulaties optreden. Op de Noordzee worden zeeprikken slechts incidenteel aangetroffen. In de kustzone zijn de waarnemingen talrijker. Dit verschil is zeer waarschijnlijk beïnvloed door het trekgedrag in relatie tot de voortplanting en de grotere monsterinspanning in de kustzone. De zeeprik trok vroeger vanuit de Noordzee in de rivieren stroomopwaarts, in de Rijn tot Basel en in de Maas tot diep in België. Ook in de Schelde en de Eems is de zeeprik van nature aanwezig. Het aantal waarnemingen van de soort in de grote rivieren is vanaf 1960 sterk afgenomen en vertoont een dieptepunt in de jaren '70 en '80. Toch is de soort nooit geheel verdwenen uit de Maas en Rijn. De zeeprik gebruikt ons land vooral als opgroeigebied voor de larven (ammocoeten) en als doortrekgebied voor volwassen dieren (adulten) die op weg zijn naar geschikte paaiplaatsen in Duitsland en België. Mogelijk bevinden zich echter ook in ons land paaiplaatsen: zo zijn bijvoorbeeld in de Roer (zijrivier Maas te Roermond) sinds 2004 ammocoeten gevonden en zijn in 2009 en 2010 ook enkele volwassen paairijpe zeeprikken waargenomen. Zeeprikken gezenderd bij Lith in de Maas trekken relatief snel door richting bovenstroomse gebieden, waarbij in enkele dagen $120 \mathrm{~km}$ afgelegd is met een gemiddelde snelheid van $0.7 \mathrm{~m} / \mathrm{s}$. Ook bestaat de indruk dat zeeprikken meer stroomafwaarts in de Maas paaien, aangezien er dode zeeprikken gevonden zijn in juni/juli bij Lith. De Maas mondt uit in het Haringvliet en is van belang voor zeeprik.

Telemetrieonderzoek met zeeprikken wees uit dat van de 50 stuks er zes via de spuisluizen van het Haringvliet, mogelijk twee via de vissluizen en zes via de Nieuwe Waterweg ${ }^{8}$, naar binnen zijn getrokken (Vis and Spierts 2010). Evenals bij de Afsluitdijk (Griffioen et al. 2014) benutten een deel van zeeprikken de eerste en de laatste periode van het spuien wanneer de stroomsnelheid van het water lager is vanwege een beperkter peilverschil, dan in het midden van het spuivenster.

\section{De effecten van de Kier}

De intrekmogelijkheden van zeeprik zullen toenemen met het instellen van de Kier. Aangezien de intrekperiode in het voorjaar valt (wanneer de intrekmogelijkheden via de Kier veelal goed zijn) zal er een veel groter deel van het aanbod aan zeeprik naar binnen kunnen trekken. Naar verwachting is dit een belangrijke beperkende factor voor de huidige zeeprik populatie. Er lijken voldoende potentiële paaien opgroeiplaatsen aanwezig in het achterland om ook daadwerkelijk en toename in de totale populatie van zeeprik te kunnen verwachten met de Kier.

\footnotetext{
${ }^{8}$ Hieruit blijkt dat de intrek van grotere diadrome vis niet geheel en alleen afhankelijk is van de Kier in het Haringvliet. Het Haringvliet is naar de Nieuwe Water en de Afsluitdijk één van de intrekmogelijkheden voor sterke zwemmers als de zalm en zeeforel (Bij de Vaate et al. 2003)
} 


\subsubsection{Overzicht, prognose effect van de Kier op de 16 soorten van de vismigratiekalender}

De prognose voor de 16 soorten van de vismigratie kalender verschilt van soort tot soort en is samengevat in Tabel 3. Hierbij is het vooral van belang in hoeverre zij afhankelijk zijn voor de intrek van het Haringvliet en welk aandeel het Haringvliet heeft op de populatie als geheel.

Tabel 3 Effecten van de kier op 16, door de Droomfondspartners aangewezen, soorten en de prognose voor de populatie (of aantallen in het Haringvliet)

\begin{tabular}{|c|c|c|}
\hline Soort & Effecten Kier & Prognose populatie \\
\hline Europese Aal (Anguilla anguilla) & $\begin{array}{l}\text { Schieraal: geen effect. } \\
\text { Glasaal: betere } \\
\text { intrekmogelijkheden }\end{array}$ & $\begin{array}{l}\text { Het Haringvliet is slechts één van de vele wateren } \\
\text { waar aal kan opgroeien. Daarnaast is het herstel van } \\
\text { de aal afhankelijk van vele andere factoren. Het } \\
\text { herstel van migratie als gevolg van de Kier zal } \\
\text { bijdragen aan het herstel van de aal. Het is onbekend } \\
\text { hoe groot deze bijdrage is ten opzichte van de gehele } \\
\text { populatie. }\end{array}$ \\
\hline Elft (Alosa alosa) & $\begin{array}{l}\text { Volwassen elft: betere } \\
\text { intrekmogelijkheden }\end{array}$ & $\begin{array}{l}\text { In hoeverre de Kier ook gaat leiden tot een toename } \\
\text { in de populatieomvang hangt verder af van in } \\
\text { hoeverre andere factoren het herstel van de elft- } \\
\text { populatie blijven beïnvloeden (zoals visserij en } \\
\text { habitatkwaltiet) en is op voorhand moeilijk in te } \\
\text { schatten. }\end{array}$ \\
\hline Fint (Alosa fallax) & Betere intrekmogelijkheden & $\begin{array}{l}\text { Voor fint is de verwachting dat een verdergaand } \\
\text { herstel naar estuariene omstandigheden nodig is om } \\
\text { de paai- en opgroeifunctie voor deze soort voldoende } \\
\text { te herstellen. }\end{array}$ \\
\hline Rivierprik (Lampetra fluviatlis ) & Betere intrekmogelijkheden & $\begin{array}{l}\text { Er wordt een toename van de benutting van het } \\
\text { aantal paai en opgroeiplaatsen verwacht doordat de } \\
\text { intrekmogelijkheden worden vergroot. }\end{array}$ \\
\hline Spiering (Osmerus eperlanus) & Betere intrekmogelijkheden & $\begin{array}{l}\text { De soort zal toenemen in het Haringvliet. Te meer } \\
\text { omdat spiering goed kan omgaan met langere } \\
\text { perioden met volledig zoet water. }\end{array}$ \\
\hline Sprot (Sprattus sprattus) & $\begin{array}{l}\text { Het is onzeker hoe sprot zich } \\
\text { zal gaan gedragen t.o.v. de } \\
\text { Kier. Mogelijk vergelijkbaar } \\
\text { als haring. }\end{array}$ & $\begin{array}{l}\text { Indien vergelijkbaar als haring, dan zullen de } \\
\text { aantallen in het Haringvliet toenemen. }\end{array}$ \\
\hline Europese steur (Acipenser sturio ) & Betere intrekmogelijkheden & $\begin{array}{l}\text { Voor de terugkomst van de steur is meer nodig dan } \\
\text { alleen de Kier. }\end{array}$ \\
\hline Atlantische zalm (Salmo salar) & Betere intrekmogelijkheden & $\begin{array}{l}\text { Voor het herstel/vergroten van de zalmpopulatie is } \\
\text { meer nodig dan alleen de Kier. }\end{array}$ \\
\hline Zeebaars (Dicentrarchus labrax) & $\begin{array}{l}\text { Betere intrekmogelijkheden } \\
\text { (vergelijkbaar met } \\
\text { dunlipharder) }\end{array}$ & $\begin{array}{l}\text { Voor de Noordzee populatie zeebaars zal de Kier } \\
\text { weinig tot geen betekenis hebben, toch zal het lokale } \\
\text { voorkomen van zeebaars in het brakkere eerste deel } \\
\text { van het Haringvliet naar verwachting toenemen. }\end{array}$ \\
\hline Zeeforel (Salmo trutta trutta ) & Betere intrekmogelijkheden & $\begin{array}{l}\text { De Kier geeft een grotere draagtkracht voor de } \\
\text { zeeforel populatie. }\end{array}$ \\
\hline Zeeprik (Petromyzon marinus) & $\begin{array}{l}\text { Betere intrekmogelijkheden } \\
\text { (zie rivierprik) }\end{array}$ & $\begin{array}{l}\text { Er wordt een toenname van de benutting van het } \\
\text { aantal paai en opgroeiplaatsen verwacht. }\end{array}$ \\
\hline
\end{tabular}




\subsection{Consequenties van De Kier voor trekvis: Q\&A's}

\section{Is het een probleem dat in droge tijden de sluizen van de Haringvlietsdam worden gesloten?}

Ja, met name voor najaarsmigranten zullen de intrekvensters sterk worden beperkt door het sluiten van de sluizen in de Haringvlietdam gedurende droge perioden. Voor de continuïteit van een zoet-zout gradiënt is dit ook zeer nadelig. Indien de Haringvlietdam voor langere periode gesloten wordt, zal zich periodiek opnieuw een zeer onnatuurlijke 'harde' zoet-zout overgang ontwikkelen en zal de beoogde brakwaterzone dus ook tijdelijk geheel verdwijnen. Voor zoutwater soorten die in het Haringvliet terecht zijn gekomen is dit dodelijk als ze er niet in slagen om tijdens het zoetspoelen met de naar zee verplaatste zoet-zout gradiënt mee te bewegen. Het is daarnaast mogelijk dat zoutwater soorten 'gevangen' raken in de diepere zoutere delen van het Haringvliet. Indien deze delen met de tijd 'verzoeten' zullen zij alsnog geconfronteerd worden met een dodelijk lage zout concentratie. Voor zoetwatersoorten die uitgespoeld geldt eveneens dat deze buitengaats dan gevangen raken in te zoute omstandigheden en slechts zeer beperkte tijd hebben om de schaarse intrek mogelijkheden te zoeken (alleen via de vissluizen en scheepsluis, want de Kier is dan niet in werking). Voor trekvissen die juist gedurende perioden migreren dat de kans op droge perioden groot is (met name in het najaar) vertraagd en wellicht blokkeert dit de optrekmogelijkheden. Denk daarbij aan soorten zoals rivierprik, houting, zalm en zeeforel.

\section{Hoe goed wordt migrerende vis bediend door een ingaande vloedstroming?}

Hoe meer sluizen geopend zijn hoe beter de intrekmogelijkheden naar het Haringvliet, en hoe groter de vindbaarheid van de intrekvensters zal zijn. Desalniettemin, hoe goed deze vensters benut zullen worden bij een afnemend aantal geopende sluizen en een afnemende grootte van de opening per sluis, en onder welke omstandigheden dit plaats gaat vinden, is nu niet goed bekend. Dit zou onderdeel moeten worden van de leervragen die ten grondslag liggen aan het 'lerend implementeren'. Om de intrekmogelijkheden voor alle scenario's te optimaliseren zal de intrekefficiëntie moeten worden bepaald gedurende verschillende spuidebieten en sluisdeur configuraties. Het effect zal sterk afhankelijk zijn van het gedrag en de verspreiding van de (trek)vis aan de zeezijde van de Haringvlietdam en het is dan ook de verwachting dat dit soort specifiek is. Hier is nu slechts zeer beperkte kennis van. Naar verwachting zal een soort die volledig afhankelijk is van het selectief getijden transport, zoals botlarven, de intrek vooral volume gedreven zijn. Dat wil zeggen: des te groter het volume water is dat naar binnen kan via de Haringvlietdam, des te grotere aantallen botlarven mee zullen liften. Naar mate de vis groter en sterker is zal het eigen, actieve zoekgedrag een steeds grotere rol gaan spelen in de mate waarin de intrekvensters van de kier kunnen worden benut. Ook hier moet meer kennis over worden ontwikkelt. De sterkste zwemmers, zeeforel en zalm, welke nu ook al gedeeltelijk naar binnen kunnen trekken, zullen met de Kier minder intrekbeperkingen kennen. Optimalisatie van de configuratie van de spuisluizen (ook om daarmee stroomsnelheden af te zwakken) gedurende zowel het spuien als het kieren (inlaten) zal ongetwijfeld de intrekmogelijkheden nog meer vergroten.

\section{Wat is de minimum afvoer om schieraal op zee te krijgen via de Haringvlietdam?}

Hier is in het verleden onderzoek naar gedaan, en in de huidige situatie (LPH84) waarbij schieraal met name met veel afvoer naar buiten trekken via de sluizen (Winter and Bierman 2010). Bij een geringere afvoer via de Haringvlietdam trekken de schieralen doorgaans via het Spui en de Nieuwe Waterweg naar zee of zij blijven langer op het Haringvliet wachten op een volgende, hogere rivierafvoer (Winter and Bierman 2010). Het is goed mogelijk dat bij lagere afvoeren (maar genoeg om nog te spuien via het Haringvliet) en een meer permanente zoet-zout gradiënt met de komst van de Kier, de schieraal beter naar de spuisluizen zal geleiden, dan in de huidige situatie het geval is. En dat onder die situatie de schieraal ook bij mindere afvoer al via de spuisluizen naar buiten zullen trekken.

\section{Is een toenemende inlaat van zeewater met één tot vier deuren op $40 \mathrm{~cm}$ de beste oplossing?}

Het is op dit moment onduidelijk wat de beste oplossing hiervoor is, d.w.z. wat de optimale configuratie is van de sluisdeuren (en onder welke omstandigheden) om bij vloed water en vis vanuit de Voordelta in te laten in het Haringvliet. Om deze reden is het lerend implementeren van belang, waarbij gezocht wordt naar 'de beste' oplossing. Teven zal de beste oplossing mogelijk variëren per soort. In het algemeen zal het lerend implementeren aangegrepen moeten worden om het beheersysteem 
bijvoorbeeld te testen met aan de ene kant veel deuren deels open ten opzichte van weinig deuren volledig open (en eventueel de variaties er tussen in).

\section{Wat is het effect van zoetspoelen (incl. zoet worden van diepe putten) op vissen?}

Bij het zoetspoelen wordt geen zeewater meer in het Haringvliet ingelaten en de sluizen gaan dicht bij vloed. Een zoetgespoeld Haringvliet kan per jaar tot 90 dagen aaneengesloten optreden, zoals dit is vastgesteld gebaseerd op 100 jaar metingen van Rijnafvoer (Paalvast, 2016). Dit geeft een contrast met de natuurlijke situatie waarbij juist in droge perioden het zoute water het verst landinwaarts trekt. Het zoetspoelen zal naar verwachting het vaakst voorkomen in de maanden september-oktober. Dit heeft met name betrekking op de najaarsmigranten (zie vraag 1), maar zij zullen wel gehinderd worden door een 'dichte deur' van het Haringvliet, en dit geldt voor de trekvissen van de Rijn maar zeker ook voor die van de Maas die vanuit meer zuidelijke richting het Haringvliet instroomt. Een gesloten Haringvliet betekend voor trekvissen van de Maas een aanzienlijke, onnatuurlijke omweg. Met name voor soorten waarbij de corridor functie van groot belang is, zal het zoetspoelen en daardoor een beperkte migratie mogelijkheid een probleem op kunnen leveren (rivierprik en zalm). Voor soorten met het estuarium als habitat functie geldt ook dat dit een probleem kan opleveren doordat er geen brakke zone meer is (steur, elft, bot, spiering, driedoornige stekelbaars en houting). Echter, de mate van afhankelijkheid van het estuarium verschilt per soort. Zo kunnen spiering, houting en bot bijvoorbeeld prima leven in volledig zoet water, terwijl een soort als steur en elft tijdens bepaalde levensstadia meer afhankelijk lijken te zijn van een goed functionerend estuarium. Fint zal met de Kier zeer waarschijnlijk niet gaan terugkeren in het Haringvliet en achterland (om te paaien). Zoetspoelen zal voor fint daarom niet van belang zijn voor het bijdragen aan het herstel van de populatie. Dat is pas aan de orde als er een verdergaand herstel van het estuariene karakter van het Haringvliet plaats gaat vinden. 


\section{Literatuur}

Bemmelen, A. A. 1866. Lijst van visschen in Nederland waargenomen. In: Herklots, J.A. (Ed.), Bouwstoffen voor eene Fauna van Nederland,. E.J. Brill, Leyden, pp. 318-413.

Bergstedt, R. A., and J. G. Seelye. 1995. EVIDENCE FOR LACK OF HOMI NG BY SEA LAMPREYS. Transactions of the American Fisheries Society 124:235-239.

Bij de Vaate, A., A. W. Breukelaar, T. Vriese, G. De Laak, and C. Dijkers. 2003. Sea trout migration in the Rhine delta. Journal of Fish Biology 63:892-908.

Bjerselius, R., W. M. Li, J. H. Teeter, J. G. Seelye, P. B. Johnsen, P. J. Maniak, G. C. Grant, C. N. Polkinghorne, and P. W. Sorensen. 2000. Direct behavioral evidence that unique bile acids released by larval sea lamprey (Petromyzon marinus) function as a migratory pheromone. Canadian Journal of Fisheries and Aquatic Sciences 57:557-569.

Borcherding, J., C. Pickhardt, H. V. Winter, and J. S. Becker. 2008. Migration history of North Sea houting (Coregonus oxyrinchus L.) caught in Lake IJ sselmeer (The Netherlands) inferred from scale transects of Sr-88: Ca-44 ratios. Aquatic Sciences 70:47-56.

Borcherding, J., A. Scharbert, and R. Urbatzka. 2006. Timing of downstream migration and food uptake of juvenile North Sea houting stocked in the Lower Rhine and the Lippe (Germany). Journal of Fish Biology 68: 1271-1286.

Bos, A. R. 1999. Tidal transport of flounder larvae (Pleuronectes flesus) in the Elbe River, Germany. Archive of Fishery and Marine Research 47:47-60.

Bos, A. R., and R. Thiel. 2006. Influence of salinity on the migration of postlarval and juvenile flounder Pleuronectes flesus L. in a gradient experiment. Journal of Fish Biology 68: 1411-1420.

Breukelaar, A. W., A. bij de Vaate, and K. T. W. Fockens. 1998. Inland migration study of sea trout (Salmo trutta) into the rivers Rhine and Meuse (The Netherlands), based on inductive coupling radio telemetry. Hydrobiologia 371:29-33.

Brevé, N. W. P., H. Vis, B. Houben, G. A. J. Laak, A. W. Breukelaar, M. L. Acolas, Q. A. A. Bruijn, and I. Spierts. 2013. Exploring the possibilities of seaward migrating juvenile European sturgeon Acipenser sturio L., in the Dutch part of the River Rhine. Journal of Coastal Conservation: 1-13.

Daverat, F., P. Morais, E. Dias, J. Babaluk, J. Martin, M. Eon, R. Fablet, C. Pecheyran, and C. Antunes. 2012. Plasticity of European flounder life history patterns discloses alternatives to catadromy. Marine Ecology Progress Series 465:267-280.

de Groot, S. J. 2002. A review of the past and present status of anadromous fish species in the Netherlands: is restocking the Rhine feasible? Hydrobiologia 478:205-218.

Dekker, W. 2004a. Slipping through our hands: population dynamics of the European Eel. . PhD thesis. University of Amsterdam.

Dekker, W. 2004b. What caused the decline of the Lake IJ sselmeer eel stock after 1960? Ices Journal of Marine Science 61:394-404.

Emmerik, W. A. M., and H. W. Nie de. 2006. De zoetwatervissen van Nederland. Vereniging Sportvisserij Nederland, Bilthoven.

Esteves, E., and J. P. Andrade. 2008. Diel and seasonal distribution patterns of eggs, embryos and larvae of Twaite shad Alosa fallax fallax (Lacepede, 1803) in a lowland tidal river. Acta OecologicaInternational Journal of Ecology 34:172-185.

Feunteun, E. 2002. Management and restoration of European eel population (Anguilla anguilla): An impossible bargain. Ecological Engineering 18:575-591.

Gosset, C., J. Rives, and J. Labonne. 2006. Effect of habitat fragmentation on spawning migration of brown trout (Salmo trutta L.). Ecology of Freshwater Fish 15:247-254.

Graaf, M. d., I. J. d. Boois, O. G. Bos, A. B. Griffioen, O. v. Keeken, N. S. H. Tien, and P. d. Vries. 2016. Toestand vis en visserij in de zoete Rijkswateren 2015. Wageningen Marine Research, IJ muiden.

Graaf, M. d., N. S. H. Tien, and K. E. v. d. Wolfshaar. 2014. Report on the eel stock and eel fishery in the Netherlands in 2012. I MARES, IJ muiden.

Griffioen, A. B. 2014. Data rapportage najaar 2013 fuik monitoring Kornwerderzand t.b.v. de VismigratieRivier. IMARES, IJ muiden.

Griffioen, A. B., v. O. A. Keeken, D. Burggraaf, T. J. A. Puts, and G. Manshanden. 2013. Onderzoek vismigratie via grote sluizen: DIDSON metingen. IMARES, IJ muiden.

Griffioen, A. B., and E. Kuijs. 2013. Een eerste monitoring voor een index voor schieraal in Nederland 2012 I MARES rapport $\mathrm{nr}$ C139/13.

Griffioen, A. B., P. d. Vries, R. H. Twijnstra, and M. d. Graaf. 2017. Glass eel monitoring in the Netherlands. Wageningen Marine Research, IJ muiden. 
Griffioen, A. B., H. V. Winter, O. A. v. Keeken, C. Chen, E. v. Os-Koomen, S. Schoenlau, and T. Zawadowski. 2014. Verspreidingsdynamiek, gedrag en voorkomen van diadrome vis bij Kornwerderzand t.b.v. de VismigratieRivier. I MARES, IJ muiden.

Groeneboom, J., M. Tiessen, T. Kaaij van der, and R. Plieger. 2016. Ontwikkeling 3D Haringvlietmodel. Deltares, Delft.

Groot de, S. J. 1992. Herstel van riviertrekvissen in de Rijn een realiteit? de Fint. De Levende Natuur 93: 182-186.

Hiddema, P. 2014. Nota bediening en monitoring de Kier (definitief). Rijkswaterstaat West-Nederland Zuid.

Hoek, P. P. C. 1899. Neuere Lachs- und Maifisch studien. Tijdschrift van de Nederlandsche Dierkundige Vereeniging - tweede reeks 6:156-242.

Hoek, P. P. C., and J. M. Bottemanne. 1888. Rapport over de ankerkuil- en staalbomenvisscherij op het Hollandsch Diep en Haringvliet,. Leiden. Ook verschenen als Supplement deel II van het Tijdschrift der Neederlandsche Dierkundige Vereeniging.

Hop, J. 2011. Visstand Haringvliet en Kier. ATKB rapportnr 20110243/001.

Hop, J. 2016. Visstand Haringvliet en Voordelta - heden. ATKB rapportnr 20150469/rap01.

Houben, B., L. Linnartz, and J. Quak. 2012. De steur terug in de Rijn - de atlantische steur als kroon op het werk aan levende rivieren. ARK, Nijmegen.

Jacobs, P., B. Steenkamp, and S. Goederen de. 2003. Van zoet naar zout in 5 dagen? Analyse zoutmetingen inlaatproef Haringvliet in maart 1997., RIZA rapport 2003.001, Dordrecht.

Jager, Z. 2001. Transport and retention of flounder larvae (Platichthys flesus L.) in the Dollard nursery (Ems estuary). J ournal of Sea Research 45: 153-171.

Jager, Z., N. Jaarsma, I. De Boois, and A. B. Griffioen. 2015. Aanpassing van de KRW visindex 02 aan boomkor- en fuikmonitoring - Rapport ZW2015-02.

Jager, Z., and H. P. J. Mulder. 1999. Transport velocity of flounder larvae (Platichthys flesus L.) in the Dollard (Ems estuary). Estuarine Coastal and Shelf Science 49:327-346.

Jonsson, N., and B. Jonsson. 2002. Migration of anadromous brown trout Salmo trutta in a Norwegian river. Freshwater Biology 47:1391-1401.

Keeken, O. A. v., M. v. Hoppe, I. J. d. Boois, M. d. Graaf, A. B. Griffioen, M. Lohman, E. v. Os-Koomen, H. J. Westerink, J. A. M. Wiegerinck, and H. M. J. v. Overzee. 2016. Toestand vis en visserij in de zoete Rijkswateren 2015 Deel III: Data. Wageningen Marine Research, IJ muiden.

Kemper, J. 1997. Sonar-onderzoek naar visbewegingen onder invloed van het openstellen van de Haringvlietsluizen in 1997. OVB - RWSZH/OVB 1995-02.

Kier, P. 2009. Werkplan Lerend Implementeren. Rijkswaterstaat Zuid-Holland.

Kleef, H. L., and Z. Jager. 2002. Het diadrome visbestand in het Eems-Dollard estuarium in de periode 1999 tot 2001. Rapport nr 2002.060.

Komoroske, L. M., K. M. Jeffries, R. E. Connon, J. Dexter, M. Hasenbein, C. Verhille, and N. A. Fangue. 2016. Sublethal salinity stress contributes to habitat limitation in an endangered estuarine fish. Evolutionary Applications 9: 963-981.

LANUV. 2011. Herintroductie van de elft (meivis, Alosa alosa) in het Rijnsysteem. Landesamt für Natur, Umwelt und Verbraucherschutz Nordrhein-Westfalen-Fachbericht 28.

Leeuwen, F. V., P. Jacobs, and K. Storm. 2004. Haringvlietsluizen op een Kier - Effecten op natuur en gebruiksfuncties Ministerie van Verkeer en Waterstaat en Ministerie van Landbouw, Natuur en Voedselkwaliteit - Stuurgroep Realisatie de Kier, september 2004 - AP/2004.07

Lochet, A., S. Boutry, and E. Rochard. 2009. Estuarine phase during seaward migration for allis shad Alosa alosa and twaite shad Alosa fallax future spawners. Ecology of Freshwater Fish 18:323-335.

Lucas, M. C., and E. Barras. 2001. Migration of freshwater fishes. Blackwell Science Ltd.

Maitland, P. S., and A. A. Lyle. 2005. Ecology of Allis Shad Alosa alosa and Twaite Shad Alosa fallax in the Solway Firth, Scotland. Hydrobiologia 534:205-221.

Morais, P., E. Dias, J. Babaluk, and C. Antunes. 2011. The migration patterns of the European flounder Platichthys flesus (Linnaeus, 1758) (Pleuronectidae, Pisces) at the southern limit of its distribution range: Ecological implications and fishery management. Journal of Sea Research 65:235-246.

Noordhuis, R. 2017. Het Haringvliet na de Kier - Samenvatting hydrologische prognoses ten behoeve van effectinschatting op vis en vogels. Deltares rapportnr 11200539-002.

Paalvast, P. 2016. Monitoringsplan ecologie project Kierbesluit., Ecoconsult rapport 2016-01, Vlaardingen.

Poulsen, S. B., L. F. Jensen, C. Schulz, M. Deacon, K. E. Meyer, T. Jager-Kleinicke, H. Schwarten, and J. C. Svendsen. 2012. Ontogenetic differentiation of swimming performance and behaviour in relation to habitat availability in the endangered North Sea houting (Coregonus oxyrinchus). Aquatic Living Resources 25:241-249.

Quak, J. 2016. Van aal tot zalm tussen zoet en zout: : een beschouwing over de visstand in het Haringvliet, Hollands Diep en Goereesche Gat tussen 1870-1970. Sportvisserij Nederland, Bilthoven.

Savenije, H. G. 2012. Salinity and tides in alluvial estuaries. Delft University of Technology.

Schneider, J. 2009. Fischökologische Gesamtanalyse einschließlich Bewertung der Wirksamkeit der 
laufenden und vorgesehenen Maßnahmen im Rheingebiet mit Blick auf die Wiedereinführung von Wanderfischen. Bericht Nr. 167, Internationale Kommission zum Schutz des Rheins (IKSR), 165 pp.

Sluis, M. T. v. d., H. M. J. v. Overzee, N. S. H. Tien, M. d. Graaf, A. B. Griffioen, O. A. v. Keeken, E. v. OsKoomen, A. D. Rippen, J. A. M. Wiegerinck, and K. E. v. d. Wolfshaar. 2014. Toestand vis en visserij in de zoete Rijkswateren. Deel II: Methoden. I MARES, IJ muiden.

Spikmans, F., N. Kessel van, M. Dorenbosch, J. Kranenbarg, J. Bosveld, and R. Leuven. 2010. Plaag Risico Analyses van tien exotische vissoorten in Nederland Natuurbalans - Limes Divergens, Stichting RAVON, Radboud Universiteit Nijmegen \& Stichting Bargerveen, Nijmegen Rapportnr 2009-25

Tulp, I., M. Keller, J. Navez, H. V. Winter, M. de Graaf, and W. Baeyens. 2013. Connectivity between Migrating and Landlocked Populations of a Diadromous Fish Species Investigated Using Otolith Microchemistry. PLOS ONE 8.

van der Molen, D. T. r. 2012. Referenties en maatlatten voor natuurlijke watertypen voor de kaderrichtlijn water 2015-2021. 2012-31, STOWA.

Vethaak, A. D. 2013. Disease prevalence in flounder (Platichthys flesus) from the Dutch Wadden Sea as indicator of environmental quality: A summary of 1988-2005 surveys. Journal of Sea Research 82: 142-152.

Vis, H. 2017. Onderzoek naar de intrekmogelijkheden voor snoekbaars na uitspoeling via de Haringvlietdam., VisAdvies rapportnr VA2016_16.

Vis, H., and I. Spierts. 2010. Migratieonderzoek zeeprik Stellendam 2010. VisAdvies BV, Nieuwegein Projectnummer VA2010_08.

Vrieze, L. A., and P. W. Sorensen. 2001. Laboratory assessment of the role of a larval pheromone and natural stream odor in spawning stream localization by migratory sea lamprey (Petromyzon marinus). Canadian J ournal of Fisheries and Aquatic Sciences 58: 2374-2385.

Wiegerinck, J. A. M., I. J. d. Boois, O. A. v. Keeken, and H. J. Westerink. 2009. Jaarrapportage Passieve Vismonitoring Zoete Rijkswateren: fuik- en zalmsteekregistraties in 2008. IMARES, IJ muiden.

Williot, P., E. Rochard, G. Castelnaud, T. Rouault, R. Brun, M. Lepage, and P. Elie. 1997. Biological characteristics of European Atlantic sturgeon, Acipenser sturio, as the basis for a restoration program in France. Environmental Biology of Fishes 48: 359-372.

Williot, P., Rochard, E., Desse-Berset, N., Kirschbaum, F., Gessner, J. (Eds.). . 2011. Biology and Conservation of the European Sturgeon Acipenser sturio L. 1758. The Reunion of the European and Atlantic Sturgeons. Springer Heidelberg, Dordrecht, New Yrok, London.

Winter, H. V. 2007. A fisheye view on fishways. PhD Thesis, Wageningen University The Netherlands.

Winter, H. V., and S. M. Bierman. 2010. De uitrekmogelijkheden voor schieraal via de haringvlietsluizen I MARES rapport $\mathrm{nr}$ C155/10.

Winter, H. V., J. J. de Leeuw, and J. Bosveld. 2008. Houting in het IJ sselmeergebied. Een uitgestorven vis terug? - IMARES rapport nr C084/08.

Winter, H. V., A. B. Griffioen, and O. A. v. Keeken. 2014. De Vismigratierivier: Bronnenonderzoek naar gedrag van vis rond zoet - zout overgangen. I MARES, IJ muiden.

Winter, H. V., L. R. Teal, K. E. v. d. Wolfshaar, A. B. Griffioen, B. Houben, and N. W. P. Breve. 2015. Deskstudy on habitat quality for the European Sturgeon in the Dutch Rhine and southern North Sea. IMARES, IJ muiden.

Wirth, T., and L. Bernatchez. 2003. Decline of North Atlantic eels: a fatal synergy? Proceedings of the Royal Society B-Biological Sciences 270:681-688.

Wolfshaar, K. E. v. d., N. S. H. Tien, A. B. Griffioen, H. V. Winter, and M. d. Graaf. 2015. Evaluation of the Dutch Eel Management Plan 2015: status of the eel population in the periods 2005 - 2007, 2008 2010 and 2011 - 2013. I MARES Wageningen UR, IJ muiden. 


\section{Kwaliteitsborging}

Wageningen Marine Research beschikt over een ISO 9001:2008 gecertificeerd kwaliteitsmanagementsysteem (certificaatnummer: 187378-2015-AQ-NLD-RvA). Dit certificaat is geldig tot 15 september 2018. De organisatie is gecertificeerd sinds 27 februari 2001. De certificering is uitgevoerd door DNV Certification B.V. 


\section{Verantwoording}

Rapport C081/17

Projectnummer: 4316100058

Dit rapport is met grote zorgvuldigheid tot stand gekomen. De wetenschappelijke kwaliteit is intern getoetst door een collega-onderzoeker en het verantwoordelijk lid van het managementteam van Wageningen Marine Research

Akkoord:

Edward Schram

Onderzoeker

Handtekening:

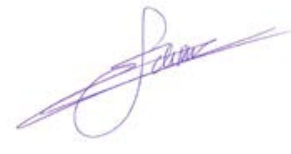

Datum:

23 oktober 2017

Akkoord:

Jakob Asjes

MT lid

Handtekening:

Datum:

23 oktober 2017 
Wageningen Marine Research

$\mathrm{T}:+31(0) 317480900$

E: marine-research@wur.nl

www. wur.nl/marine-research

Visitors address

- Ankerpark 271781 AG Den Helder

- Korringaweg 5, 4401 NT Yerseke

- Haringkade 1, 1976 CP IJ muiden
Wageningen Marine Research is the Netherlands research institute established to provide the scientific support that is essential for developing policies and innovation in respect of the marine environment, fishery activities, aquaculture and the maritime sector.

Wageningen University \& Research is specialised in the domain of healthy food and living environment.

The Wageningen Marine Research vision:

'To explore the potential of marine nature to improve the quality of life.'

\section{The Wageningen Marine Research mission}

- To conduct research with the aim of acquiring knowledge and offering advice on the sustainable management and use of marine and coastal areas.

- Wageningen Marine Research is an independent, leading scientific research institute.

Wageningen Marine Research is part of the international knowledge organisation Wageningen UR (University \& Research centre). Within Wageningen UR, nine specialised research institutes of Stichting Wageningen Research (a Foundation) have joined forces with Wageningen University to help answer the most important questions in the domain of healthy food and living environment. 